\title{
Stratigraphic Profiles for Selected Hanford Site Seismometer Stations and Other Locations
}

GV Last

February 2014

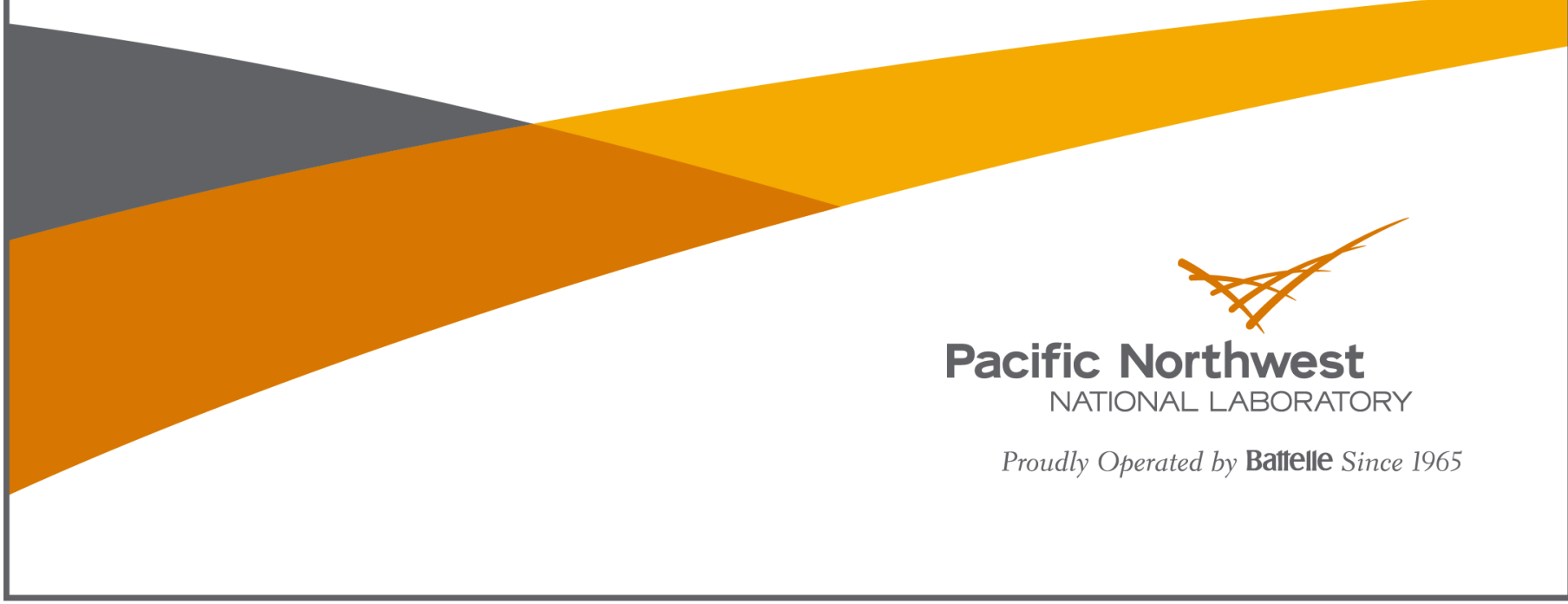




\title{
DISCLAIMER
}

This report was prepared as an account of work sponsored by an agency of the United States Government. Neither the United States Government nor any agency thereof, nor Battelle Memorial Institute, nor any of their employees, makes any warranty, express or implied, or assumes any legal liability or responsibility for the accuracy, completeness, or usefulness of any information, apparatus, product, or process disclosed, or represents that its use would not infringe privately owned rights. Reference herein to any specific commercial product, process, or service by trade name, trademark, manufacturer, or otherwise does not necessarily constitute or imply its endorsement, recommendation, or favoring by the United States Government or any agency thereof, or Battelle Memorial Institute. The views and opinions of authors expressed herein do not necessarily state or reflect those of the United States Government or any agency thereof.

\author{
PACIFIC NORTHWEST NATIONAL LABORATORY \\ operated by \\ BATTELLE \\ for the \\ UNITED STATES DEPARTMENT OF ENERGY \\ under Contract DE-AC05-76RL01830 \\ Printed in the United States of America \\ Available to DOE and DOE contractors from the \\ Omce of Scientifle and Technical Information. \\ P.O. Box 62, Oak Ridge, TN 37831-0062; \\ ph: (865) 576-8401 \\ fax: $(865)$ 576-5728 \\ email: reportsa adonis,osti.gov \\ Avallable to the public from the National Technical Information Service \\ 5301 Shawnee Rd., Alexandria, VA 22312 \\ ph: (800) \$53-NTIS (6847) \\ email: ordencintis. gov <http://www.ntis,gov/about/form.aspx $>$ \\ Online ordering: http://www.ntis,gov
}




\section{Stratigraphic Profiles for Selected Hanford Site Seismometer Stations and Other Locations}

GV Last

February 2014

Prepared for

the U.S. Department of Energy

under Contract DE-AC05-76RL01830

Pacific Northwest National Laboratory

Richland, Washington 99352 


\section{Summary}

General stratigraphic profiles down to the top of the Wanapum Basalt have been estimated for each of the Hanford Site's eight strong motion accelerometer stations, seven regional three-component broadband seismometer stations, and five key Hanford Site facility locations. In addition, stratigraphic profiles (some down to the top of the crystalline basement) were developed for these and other Pacific Northwest Seismic Network stations. These profiles provide interpretations of the subsurface layers to support estimation of ground motions at the top of the Wanapum Basalt from recorded earthquakes and the prediction of ground motions from potential future earthquakes.

The general approach used for this study was to develop a composite one-dimensional stratigraphic profile for each site based on previous interpretations of the geologic units penetrated by boreholes nearest to the given site. In many cases, the nearest boreholes are relatively shallow and can be used only for the suprabasalt sediments and/or the top of the basalt. Deep boreholes, extending through the top of the Wanapum Basalt, are fairly sparse; the closest deep borehole is often located kilometers away from the site of interest.

A number of potential sources of uncertainty exist concerning the site locations, elevations, and extrapolation of interpreted stratigraphic contacts. Stratigraphic contacts used in this report are based on interpretation of borehole data from a number of different individuals for different environmental programs, often using different stratigraphic nomenclature. Sources of uncertainty include 1) the quality of subsurface data, which is influenced by the drilling technique, the logging of the borehole, and sample collection; 2) subtle differences between some stratigraphic units that makes identification of the stratigraphic contacts difficult; and 3) uncertainty in the geometric shape of the stratigraphic units. Where suitable, existing structure contour and isopach maps, as well as cross sections, and solid Earth model information, and on rare occasions some field checking were used to help verify or adjust station location information and the stratigraphic contacts to improve extrapolation of borehole data from distant boreholes. 


\section{Acknowledgments}

The author is grateful to David C. Lanigan, Bruce N. Bjornstad, Michele A. Chamness, Alan P. Rohay, who reviewed various versions of this report and provided valuable comments and suggestions. The author also wishes to thank David C. Lanigan for his work in generating some of the technical graphics and Susan Ennor and Kathy Neiderhiser for editorial review and document production. 


\section{Acronyms and Abbreviations}

$\begin{array}{ll}\text { CGS } & \text { Columbia Generating Station } \\ \text { DOE } & \text { U.S. Department of Energy } \\ \mathrm{ft} & \text { foot(feet) } \\ \text { GPS } & \text { global positioning system } \\ \text { ID } & \text { identification } \\ \text { HPSHA } & \text { Hanford Probabilistic Seismic Hazard Analysis } \\ \text { HGIS } & \text { Hanford Geographic Information System } \\ \text { km } & \text { kilometer(s) } \\ \mathrm{m} & \text { meter(s) } \\ \text { mi } & \text { mile(s) } \\ \text { PNNL } & \text { Pacific Northwest National Laboratory } \\ \text { PSHA } & \text { probabilistic seismic hazard analysis } \\ \text { SSHAC } & \text { Senior Seismic Hazard Analysis Committee } \\ \text { WADOE } & \text { Washington State Department of Ecology } \\ \text { WIDL } & \text { Well Information Data Lookup }\end{array}$




\section{Contents}

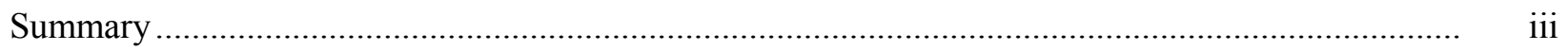

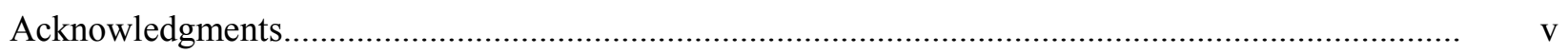

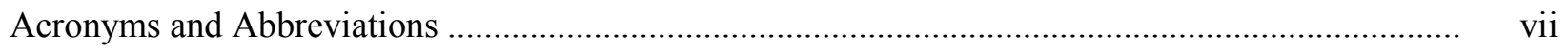

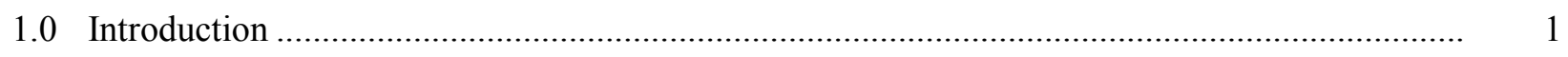

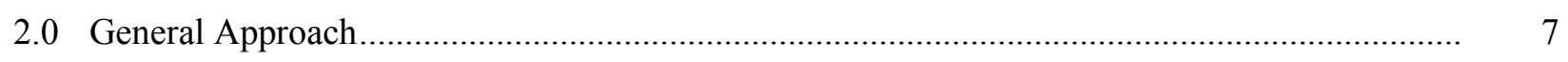

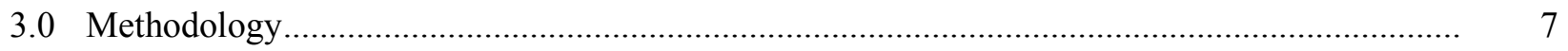

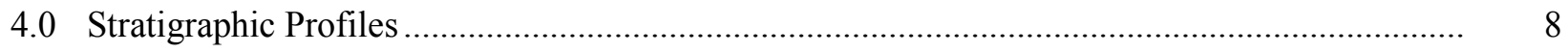

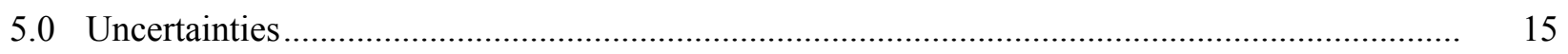

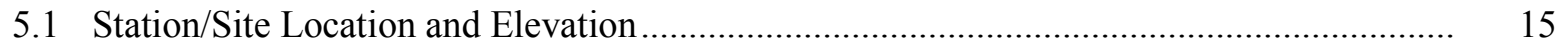

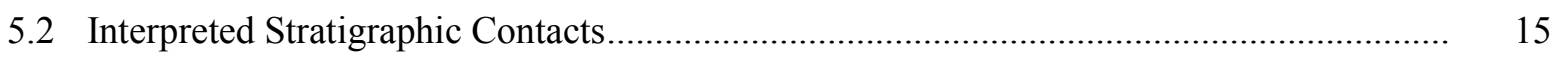

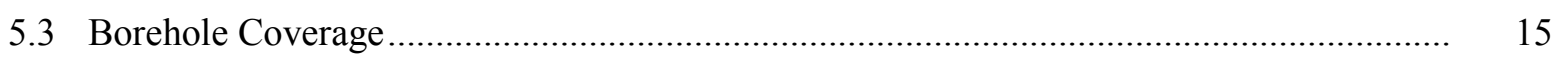

5.4 Qualitative Estimates of Uncertainty for Each Site..................................................... 15

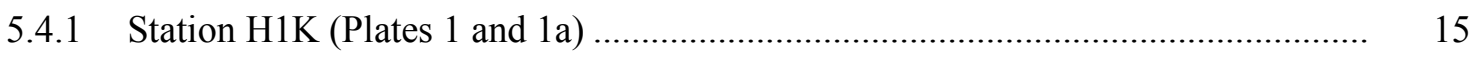

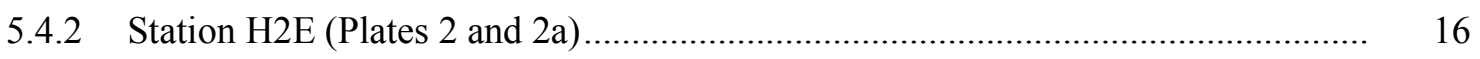

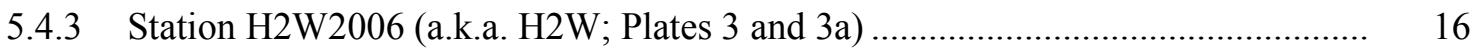

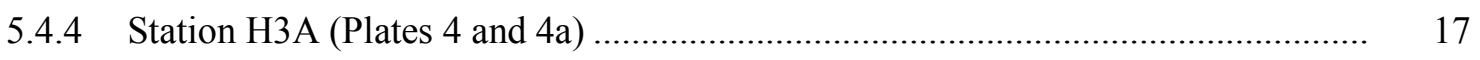

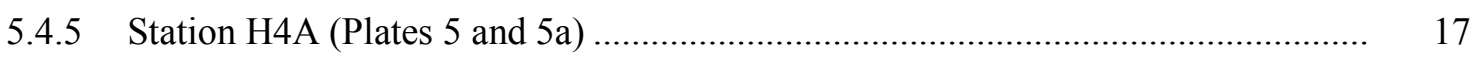

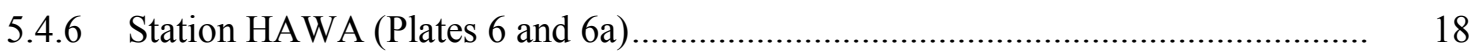

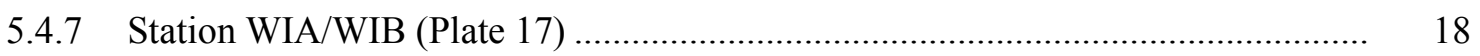

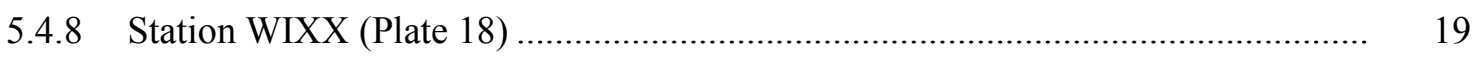

5.4.9 Reference Location A1 (Waste Treatment Plant, Plates 7 and 7a)........................ 19

5.4.10 Reference Location B and Seismometer Station H2W1998 (Plates 8 and 8a)...... 19

5.4.11 Reference Location C (Columbia Generating Station, Plates 9 and 9a)................ 20

5.4.12 Reference Location D (105-B, Plates 10 and 10a) .............................................. 21

5.4.13 Reference Location E (300 Area, Plates 11 and 11a) ........................................ 21

5.4.14 Seismometer Station CCRK (Plate 12)............................................................. 22

5.4.15 Seismometer Station DDRF (Plate 13) .............................................................. 22

5.4.16 Seismometer Station FHE (Plate 14) ................................................................ 22

5.4.17 Seismometer Station PHIN (Plate 15) ............................................................... 23

5.4.18 Seismometer Station GBB (Plate 16) ................................................................. 23

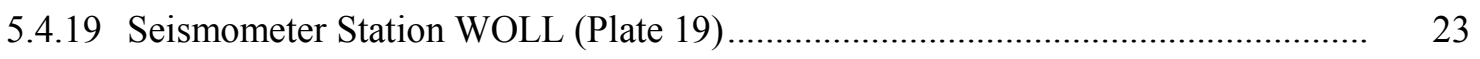

5.4.20 Seismometer Station TUCA (Plate 20)............................................................. 24

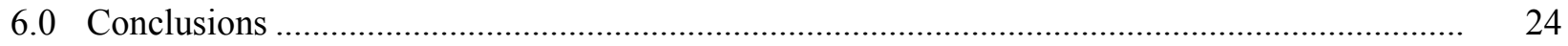

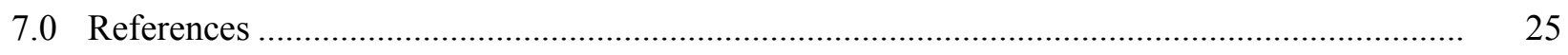

Appendix A - Stratigraphic Profiles............................................................................ A.1 


\section{Figures}

1 Hanford Site well location map showing the locations of strong motion accelerometers

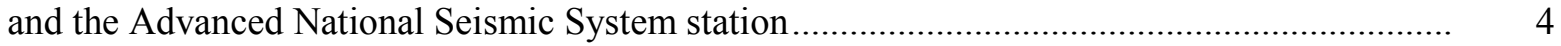

2 Locations of regional three-component broadband seismometer stations ................................. 5

3 Reference locations for ground motion hazard calculation ....................................................... 6

\section{Tables}

1 Hanford Site seismometer stations and other sites for stratigraphic profiling ........................... 1

2 General description of stratigraphic units used in this report .................................................. 9

3 Estimated depth to top contact and thickness of stratigraphic units beneath selected

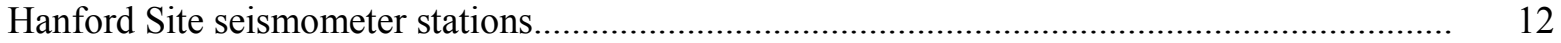

4 Estimated depth to top contact and thickness of stratigraphic units beneath selected

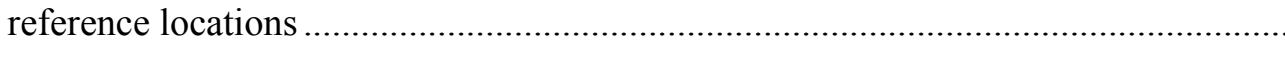

5 Estimated depth to top contact and thickness of stratigraphic units beneath selected regional three-component broadband seismometer stations. 


\subsection{Introduction}

The Pacific Northwest National Laboratory is preparing a site-wide Hanford probabilistic seismic hazard analysis (PSHA) for the U.S. Department of Energy (DOE) and Energy Northwest. The PSHA is being conducted using the processes that are appropriate for a Study Level 3 of the procedures given in the guidance advanced by the Senior Seismic Hazard Analysis Committee (SSHAC) in NUREG/CR-6372 (Budnitz et al. 1997). The specific purpose of the SSHAC Level 3 PSHA is to provide input to sitespecific ground motion assessments at particular facility sites within the Hanford Site. This includes the identification of seismic sources and characterization of those sources by their recurrence rates and maximum magnitudes and prediction of potential ground motions as a function of distance, magnitude, and other factors.

The objective of the Hanford PSHA is to develop a family of seismic hazard curves that express the annual frequency of exceeding different levels of ground motion at the top of a reference horizon or stratigraphic unit (i.e., the Wanapum Basalt). These predicted ground motions could then be used as input for future site response analyses to predict how the ground motions would be modified by site-specific properties of the soils directly beneath specific engineered structures to support design or safety review.

The stratigraphy beneath the Hanford Site and surrounding area generally consists of eight major geologic units; from youngest to oldest, these include the Hanford formation, the Cold Creek unit, the Ringold Formation, the Saddle Mountains Basalt (and interbedded Ellensburg Formation), the Wanapum Basalt, the Grande Ronde Basalt, Pre-Miocene sediments, and the crystalline basement. The objective of the study reported here was to develop a general interpretation of the stratigraphy (i.e., stratigraphic profile) down to the top of the Wanapum Basalt beneath each of the Hanford Site's eight strong motion accelerometer stations, seven regional three-component broadband seismometer stations, and five key Hanford Site facility locations. In addition, deep stratigraphic profiles (some down to the top of the crystalline basement) were developed for 11 of these locations.

These stratigraphic profiles are needed to 1) interpret the ground motions at the top of the Wanapum Basalt from past earthquakes recorded at the surface, 2) aid development of shear wave velocity profiles from Spectral Analysis of Shear Wave measurements, and 3) support ground motion hazard calculations. Table 1 lists key information for these sites. The site locations are shown in Figure 1, Figure 2, and Figure 3. Detailed stratigraphic profiles through the Saddle Mountains Basalt and suprabasalt sediments are provided in Appendix A in Plates 1-20; deep stratigraphic profiles to the top of the crystalline basement are provided in Plates 1a-11a.

Table 1. Hanford Site seismometer stations and other sites for stratigraphic profiling.

\begin{tabular}{|l|l|r|r|r|l|}
\hline $\begin{array}{c}\text { Station/ } \\
\text { Site ID }\end{array}$ & $\begin{array}{c}\text { Station/Site } \\
\text { Name }\end{array}$ & Latitude & \multicolumn{1}{c|}{ Longitude } & $\begin{array}{c}\text { Elev. } \\
(\mathrm{m})\end{array}$ & \multicolumn{1}{c|}{ Source } \\
\hline \multicolumn{6}{|c|}{ Free-Field Strong Motion Accelerometer Stations } \\
\hline H1K $^{\text {(a) }}$ & 100 K Area & $46.64183^{\circ}$ & $-119.59217^{\circ}$ & 152 & $\begin{array}{l}\text { Converted from Rohay et al. (2011) } \\
\text { Bodin et al. (2012), location verified in } \\
\text { Google Earth imagery }\end{array}$ \\
& & $\mathbf{4 6 . 6 4 4 6}^{\circ}$ & $\mathbf{- 1 1 9 . 5 9 2 9 ^ { \circ }}$ & $\mathbf{1 5 2}$ & \\
\hline
\end{tabular}


Table 1. (contd)

\begin{tabular}{|c|c|c|c|c|c|}
\hline $\begin{array}{l}\text { Station/ } \\
\text { Site ID }\end{array}$ & $\begin{array}{l}\text { Station/Site } \\
\text { Name }\end{array}$ & Latitude & Longitude & $\begin{array}{l}\text { Elev } \\
.(\mathrm{m})\end{array}$ & Source \\
\hline \multicolumn{6}{|c|}{ Free-Field Strong Motion Accelerometer Stations } \\
\hline $\mathbf{H}_{2} \mathbf{E}^{(\mathrm{a})}$ & 200 East Area & \begin{tabular}{r|}
$46.55967^{\circ}$ \\
$\mathbf{4 6 . 5 5 7 8}^{\circ}$
\end{tabular} & $\begin{array}{r}-119.53333^{\circ} \\
\mathbf{- 1 1 9 . 5 3 4 5 ^ { \circ }}\end{array}$ & $\begin{array}{l}210 \\
187\end{array}$ & $\begin{array}{l}\text { Converted from Rohay et al. (2011) } \\
\text { Bodin et al. (2012), location verified by } \\
\text { GPS on } 4 / 13 / 2013 \text {, with elevation at } 199 \\
\text { m, but topographic map suggests } \\
\text { elevation closer to } 210 \mathrm{~m} \text {. }\end{array}$ \\
\hline $\begin{array}{l}\text { H2W2006 } \\
\text { (a.k.a. }^{(\text {a) }} \\
\text { H2W) }\end{array}$ & 200 West Area & $\begin{array}{r}46.55183^{\circ} \\
\mathbf{4 6 . 5 5 1 7}^{\circ}\end{array}$ & $\begin{array}{r}-119.64400^{\circ} \\
\mathbf{- 1 1 9 . 6 4 5 3}^{\circ}\end{array}$ & $\begin{array}{l}201 \\
129\end{array}$ & $\begin{array}{l}\text { Converted from Rohay et al. (2011) } \\
\text { Bodin et al. (2012), location verified by } \\
\text { GPS on } 4 / \mathbf{1 3} / \mathbf{2 0 1 3} \text {, with elevation at } \mathbf{1 9 8} \\
\text { m. }\end{array}$ \\
\hline $\begin{array}{l}\mathrm{H} 2 \mathrm{~W} 1998 \\
\text { (a)* }\end{array}$ & 200 West Area & $46.55383^{\circ}$ & $-119.62517^{\circ}$ & 206 & Converted from Conrads (1997) \\
\hline $\mathbf{H 3 A}^{(\mathrm{a})}$ & 300 Area & $\begin{array}{r}46.36383^{\circ} \\
\mathbf{4 6 . 3 6 3 2}^{\circ}\end{array}$ & $\begin{array}{r}-119.27583^{\circ} \\
\mathbf{- 1 1 9 . 2 7 7 5 ^ { \circ }}\end{array}$ & $\begin{array}{r}119 \\
99\end{array}$ & $\begin{array}{l}\text { Converted from Rohay et al. (2011) } \\
\text { Bodin et al. (2012), location verified by } \\
\text { GPS on } 4 / \mathbf{1 0} / \mathbf{2 0 1 3} \text {, with elevation at } \mathbf{1 1 8} \\
\mathbf{m} \text {. }\end{array}$ \\
\hline H4A $\mathbf{A}^{(\mathrm{a})}$ & 400 Area & 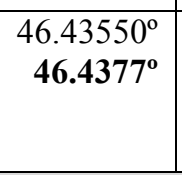 & $\begin{array}{r}-119.35500^{\circ} \\
\mathbf{- 1 1 9 . 3 5 5 7 ^ { \circ }}\end{array}$ & $\begin{array}{l}171 \\
171\end{array}$ & $\begin{array}{l}\text { Converted from Rohay et al. (2011) } \\
\text { Bodin et al. (2012), location verified by } \\
\text { GPS reading on 4/10/2013, with elevation } \\
\text { at } 160 \mathrm{~m} \text {. }\end{array}$ \\
\hline \multicolumn{6}{|c|}{ Advanced National Seismic System Backbone Station } \\
\hline HAWA ${ }^{(\text {a) }}$ & Hanford, WA & $46.39215^{\circ}$ & $-119.53244^{\circ}$ & 364 & Estimated from HGIS (Qmap) \\
\hline \multicolumn{6}{|c|}{ Three-Component Broadband Seismometer Stations ${ }^{(\mathrm{d})}$} \\
\hline CCRK & Cold Creek & \begin{tabular}{r|}
$46.93083^{\circ}$ \\
$46.559^{\circ}$ \\
$46.5585^{\circ}$ \\
$\mathbf{4 6 . 5 5 8 5 2}^{\circ}$
\end{tabular} & $\begin{array}{r}-120.42483^{\circ} \\
-119.855^{\circ} \\
-119.8548^{\circ} \\
\mathbf{- 1 1 9 . 8 5 4 8 4 ^ { \circ }} \\
\end{array}$ & $\begin{array}{l}560 \\
561 \\
561 \\
\mathbf{5 3 4}\end{array}$ & $\begin{array}{l}\text { Converted from Rohay et al. (2011) } \\
\text { Bodin et al. (2012) } \\
\text { Rodriguez-Marek Pers. Comm. }^{(\mathrm{f})} \\
\text { Rohay Pers. Comm. 9/3/13 } \\
\end{array}$ \\
\hline DDRF & Didier Farms & $\begin{array}{r}46.81867^{\circ} \\
46.491^{\circ} \\
\mathbf{4 6 . 4 9 1 1}^{\circ}\end{array}$ & $\begin{array}{r}-119.09933^{\circ} \\
-119.060^{\circ} \\
\mathbf{- 1 1 9 . 0 5 9 5}\end{array}$ & $\begin{array}{l}270 \\
233 \\
233\end{array}$ & $\begin{array}{l}\text { Converted from Rohay et al. (2011) } \\
\text { Bodin et al. (2012) } \\
\text { Rodriguez-Marek Pers. Comm. }{ }^{(\mathrm{f})}\end{array}$ \\
\hline FHE & $\begin{array}{l}\text { Frenchman } \\
\text { Hills East }\end{array}$ & $\begin{array}{r}46.95183^{\circ} \\
46.952^{\circ} \\
\mathbf{4 6 . 9 5 1 7 8}^{\circ}\end{array}$ & $\begin{array}{r}-119.49700^{\circ} \\
-119.498^{\circ} \\
\mathbf{- 1 1 9 . 4 9 8 0 9}\end{array}$ & $\begin{array}{l}455 \\
455 \\
\mathbf{4 5 5}\end{array}$ & $\begin{array}{l}\text { Converted from Rohay et al. (2011) } \\
\text { Bodin et al. (2012) } \\
\text { Rodriguez-Marek Pers. Comm. }^{(\mathrm{f})}\end{array}$ \\
\hline PHIN & Phinney Hill & $\begin{array}{r}46.49200^{\circ} \\
45.895^{\circ} \\
\mathbf{4 5 . 8 9 5 1}^{\circ}\end{array}$ & $\begin{array}{r}-120.54633^{\circ} \\
-119.928^{\circ} \\
\mathbf{- 1 1 9 . 9 2 7 8}\end{array}$ & $\begin{array}{l}227 \\
227 \\
227\end{array}$ & $\begin{array}{l}\text { Converted from Rohay et al. (2011) } \\
\text { Bodin et al. (2012) } \\
\text { Rodriguez-Marek Pers. Comm. }{ }^{\left({ }^{)}\right)}\end{array}$ \\
\hline $\mathbf{G B B}^{(\mathrm{b})}$ & Gable Butte & \begin{tabular}{r|}
$46.60817^{\circ}$ \\
$46.6081^{\circ}$ \\
$\mathbf{4 6 . 6 0 8 6 9}^{\circ}$
\end{tabular} & $\begin{array}{r}-119.62700^{\circ} \\
-119.6290^{\circ} \\
\mathbf{- 1 1 9 . 6 2 8 9 8}\end{array}$ & $\begin{array}{l}177 \\
185 \\
\mathbf{1 8 5}\end{array}$ & $\begin{array}{l}\text { Converted from Rohay et al. (2011) } \\
\text { Bodin et al. } 2012 \\
\text { Rodriguez-Marek Pers. Comm. }^{(\mathrm{f})}\end{array}$ \\
\hline \multicolumn{6}{|c|}{ Additional Spectral Analysis of Shear Wave Measurement Locations } \\
\hline WIA $^{(a, c)}$ & Wooded Is. A & $46.405735^{\circ}$ & $-119.272507^{\circ}$ & $\begin{array}{r}92 \\
118\end{array}$ & $\begin{array}{l}\text { Rohay Pers. Comm. }{ }^{(\mathrm{g})} \\
\text { Estimate from HPSHA Spatial Data } \\
\text { Viewer elev. profile tool }\end{array}$ \\
\hline $\mathbf{W I B}^{(\mathrm{a}, \mathrm{c})}$ & Wooded Is. B & $46.404751^{\circ}$ & $-119.282478^{\circ}$ & $\begin{array}{r}73 \\
112\end{array}$ & $\begin{array}{l}\text { Rohay Pers. Comm. } \\
\text { Estimate from HPSHA Spatial Data } \\
\text { Viewer elev. profile tool }\end{array}$ \\
\hline
\end{tabular}


Table 1. (cont'd)

\begin{tabular}{|c|c|c|c|c|c|}
\hline $\begin{array}{l}\text { Station/ } \\
\text { Site ID }\end{array}$ & $\begin{array}{l}\text { Station/Site } \\
\text { Name }\end{array}$ & Latitude & Longitude & $\begin{array}{l}\text { Elev } \\
.(\mathrm{m})\end{array}$ & Source \\
\hline $\mathbf{W I X X}^{(\mathrm{a})}$ & $\begin{array}{l}\text { Wooded Is. XX } \\
\text { broadband }\end{array}$ & $46.38692^{\circ}$ & $-119.274778^{\circ}$ & $\begin{array}{l}125 \\
110\end{array}$ & $\begin{array}{l}\text { Rohay Pers. Comm. }{ }^{\mathrm{g}} \\
\text { Estimate from HPSHA Spatial Data } \\
\text { Viewer elev. profile tool }\end{array}$ \\
\hline $\begin{array}{l}100 \mathrm{BC}^{(\mathrm{a})} \\
\mathbf{D}^{(\mathrm{d})}\end{array}$ & $\begin{array}{l}100 \mathrm{~B} / \mathrm{C} \text { Area; } \\
105-\mathrm{B}\end{array}$ & $46.630378^{\circ}$ & $-119.647486^{\circ}$ & 144 & $\begin{array}{l}\text { HPSHA } 2012 \text { (Workshop 1); Elevation } \\
\text { from C7847 and C8239 (WIDL) }\end{array}$ \\
\hline \multicolumn{6}{|c|}{ Other Reference Locations Slated for Hazard Calculation } \\
\hline $\begin{array}{l}\text { A } \\
\text { A1 }\end{array}$ & $\begin{array}{l}200 \text { East Area; } \\
\text { Waste } \\
\text { Treatment } \\
\text { Plant }\end{array}$ & $\begin{array}{r}46.554848^{\circ} \\
\mathbf{4 6 . 5 5 0 8 8}^{\circ}\end{array}$ & $\begin{array}{r}-119.517907^{\circ} \\
\mathbf{- 1 1 9 . 5 0 4 5 6}\end{array}$ & 206 & $\begin{array}{l}\text { HPSHA } 2012 \text { (Workshop 1) } \\
\text { Estimated from HGIS (Qmap) }\end{array}$ \\
\hline B & 200 West Area & $46.552066^{\circ}$ & $-119.625063^{\circ}$ & 206 & $\begin{array}{l}\text { HPSHA } 2012 \text { (Workshop 1) } \\
\text { Estimated from nearest wells }\end{array}$ \\
\hline $\mathbf{C}$ & $\begin{array}{l}\text { Columbia } \\
\text { Generating } \\
\text { Station (CGS) }\end{array}$ & $46.471188^{\circ}$ & $-119.334170^{\circ}$ & $134^{\mathrm{e}}$ & HPSHA 2012 (Workshop 1) \\
\hline $\mathbf{E}$ & 300 Area & $46.368604^{\circ}$ & $-119.277461^{\circ}$ & 122 & $\begin{array}{l}\text { HPSHA } 2012 \text { (Workshop 1) } \\
\text { Based on 399-3-3 }\end{array}$ \\
\hline \multicolumn{6}{|c|}{ Selected Pacific Northwest Seismic Network Stations Important for Ground Motion Analysis } \\
\hline TUCA & $\begin{array}{l}\text { Wood Farm, } \\
\text { Starbuck, WA }\end{array}$ & $46.5139^{\circ}$ & $-118.1455^{\circ}$ & 304 & Rodriguez-Marek Pers. Comm. ${ }^{(\mathrm{f})}$ \\
\hline WOLL & $\begin{array}{l}\text { Wollman } \\
\text { Farm, Schrag, } \\
\text { WA }\end{array}$ & $47.0573^{\circ}$ & $-118.921^{\circ}$ & 384 & Rodriguez-Marek Pers. Comm. ${ }^{(\mathrm{f})}$ \\
\hline $\begin{array}{l}\text { (a) Slated } \\
\text { (b) Lower } \\
\text { (c) SASW } \\
\text { (d) Slated } \\
\text { (e) From E } \\
\text { (f) Email } \\
\text { (g) Email } \\
\text { (h) Email } \\
\text { * Same as } \\
\text { Degrees, de } \\
\text { the degrees } \\
\text { Note: Ques } \\
\text { between Pa } \\
\text { elevations a }\end{array}$ & $\begin{array}{l}\text { or Spectral Analys } \\
\text { riority - not slate } \\
\text { measurements are } \\
\text { or hazard calculati } \\
\text { echtel (2013) } \\
\text { com Adrian Rodrig } \\
\text { om Alan Rohay to } \\
\text { com Alan Rohay to } \\
\text { eference location } \\
\text { cimal minutes wer } \\
\text { ionable locations } \\
1 \text { Bodin (UW) and } \\
\text { e being revised fo }\end{array}$ & $\begin{array}{l}\text { of Shear Wa } \\
\text { for SASW me } \\
\text { lated for a sing } \\
\text { n } \\
\text { lez-Marek to A } \\
\text { George Last. } \\
\text { Julian Bomme } \\
\text { was the origi } \\
\text { converted to d } \\
\text { e struck out ar } \\
\text { David Lanigan } \\
\text { the next Hanf }\end{array}$ & $\begin{array}{l}\text { e (SASW) meas } \\
\text { asurements } \\
\text { le location betw } \\
\text { lan Rohay, Subj } \\
\text { Subject: stations } \\
\text { r and others. Su } \\
\text { lal location of th } \\
\text { ecimal degrees b } \\
\text { d those used in } \\
\text { (PNNL) indicat } \\
\text { rd Seismic Rep }\end{array}$ & $\begin{array}{l}\text { ect: Sta } \\
\text { WIxx } \\
\text { ject: } \\
\text { H2W } \\
\text { y divid }\end{array}$ & $\begin{array}{l}\text { e sites } \\
\text { ion File. Dated } 2 / 8 / 2013 \text {. } \\
\text { Dated } 3 / 12 / 2013 \text {. } \\
\text { CRK Field Notes. Dated } 9 / 3 / 2013 \text {. } \\
\text { station from } 1998 \text { to } 2006 \text {. } \\
\text { ng the decimal minutes by } 60 \text { and adding to } \\
\text { y are in bold. Personal communication } \\
\text { e reported seismometer station locations and }\end{array}$ \\
\hline
\end{tabular}




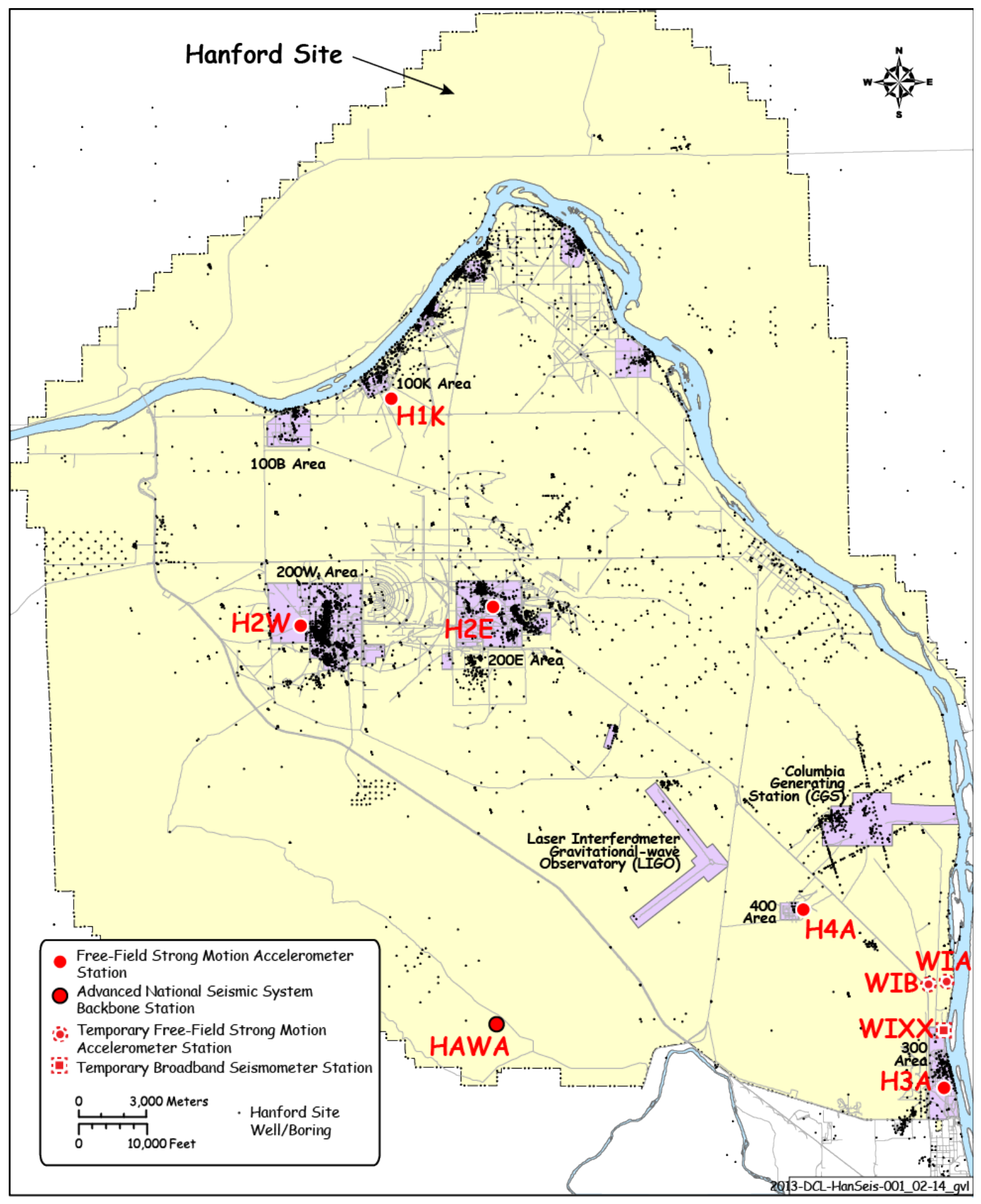

Figure 1. Hanford Site well location map showing the locations of strong motion accelerometers and the Advanced National Seismic System station. 


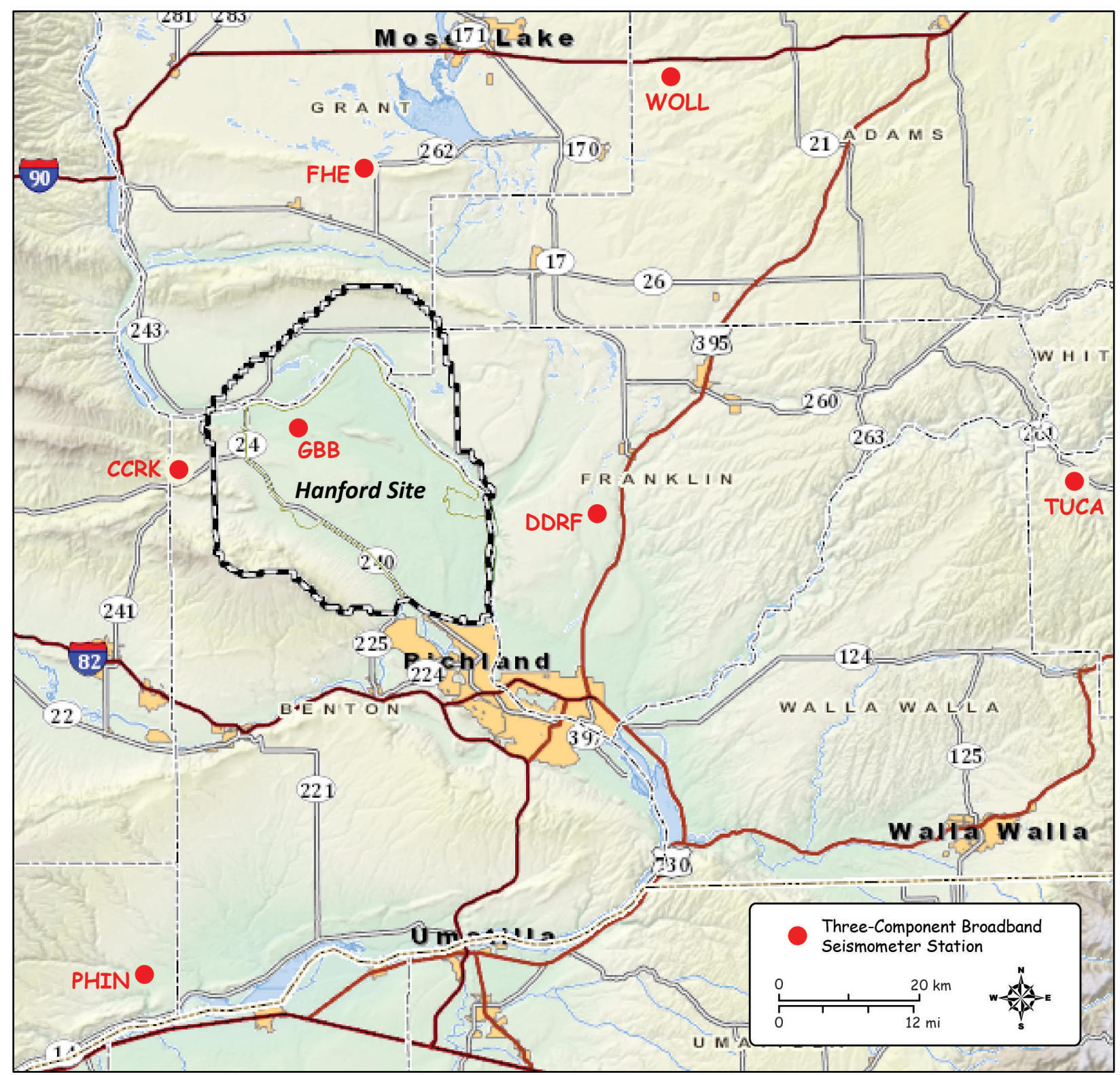

Figure 2. Locations of regional three-component broadband seismometer stations. 


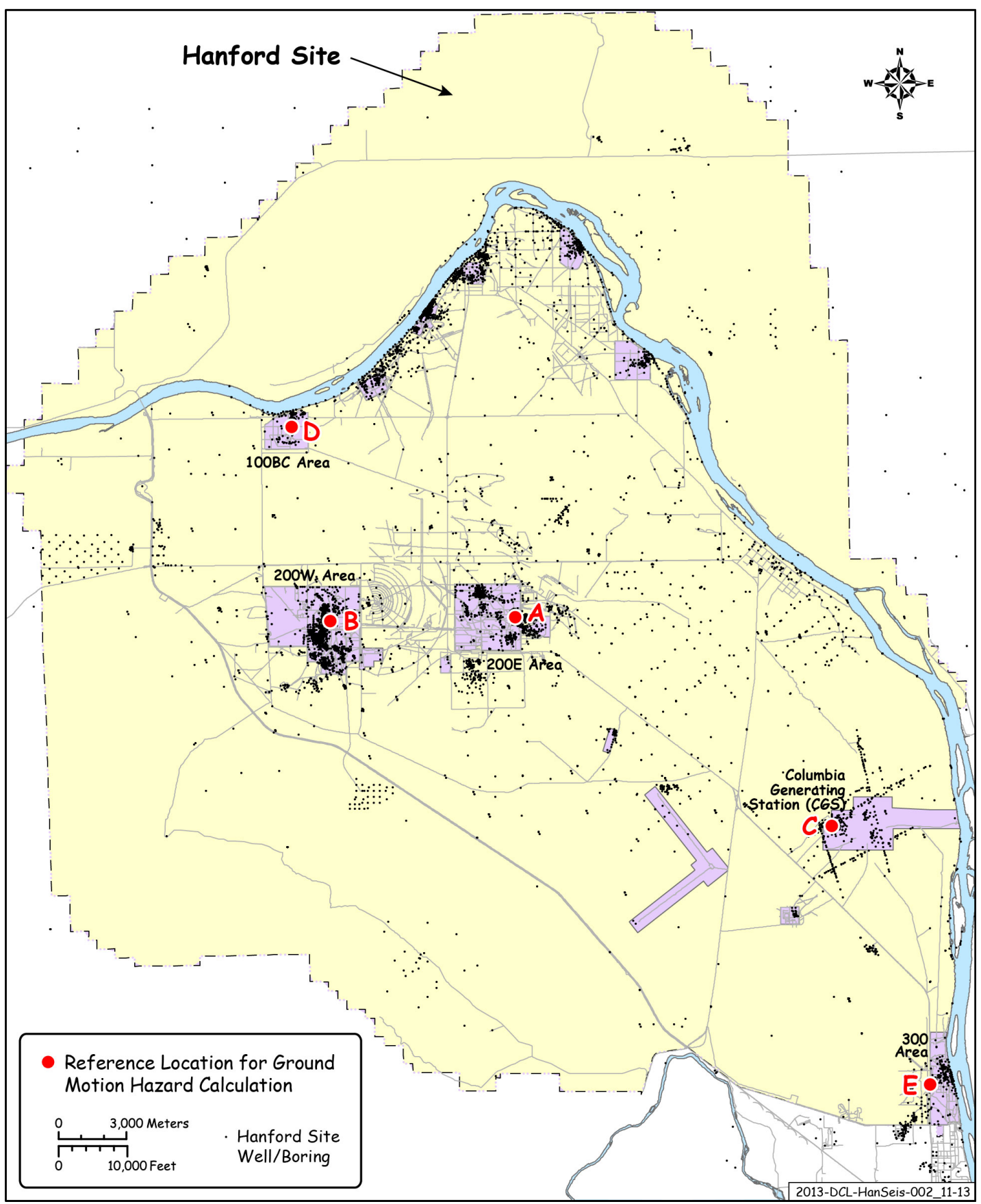

Figure 3. Reference locations for ground motion hazard calculation (after HPSHA 2013).

The sections that follow describe the study approach and methodology used, the stratigraphic profiles and technical basis (including the wells used and sources of interpreted geologic contacts) for each site, and briefly discuss the uncertainty associated with these profiles (e.g., ranges in thickness, etc.). 


\subsection{General Approach}

The general approach was to develop a composite one-dimensional stratigraphic profile for each site based on previous interpretations of the geologic units penetrated by boreholes nearest to the given site. In many cases the nearest boreholes are relatively shallow and can be used only for stratigraphic contacts for the suprabasalt sediments and the top of the basalt. Structure contour maps of the basalt surface (e.g., from Thorne et al. 2006) were often used to interpolate the depth to the top of the basalt where nearby boreholes did not reach the basalt surface.

Deep boreholes, extending through the top of the Wanapum Basalt, are fairly sparse across the Hanford Site; the closest deep borehole to a given seismometer station or reference location is often located kilometers away. Where multiple deep boreholes are available and the structural setting is similar, the average thicknesses of the Saddle Mountains Basalt flows and Ellensburg Formation interbeds are used to estimate the depth of stratigraphic contacts. Where available, existing structure contour and isopach maps, as well as cross sections, are used to help verify or adjust the estimated stratigraphic contact depths.

Deep stratigraphic information (i.e., below the top of the Wanapum Basalt) was extracted from a solid Earth geologic model developed for Art Frankle by Paul Thorne, using EarthVision ${ }^{\mathrm{TM}}$ software (Thorne et al. in press).

\subsection{Methodology}

The methodology and technical basis used to develop the stratigraphic profiles evolved during development of the profiles for the first few sites (e.g., H1K, HAWA, H2E, and H2W), and varied somewhat from site to site, depending on the available data. The general methodology used for locations within the Hanford Site consisted of the following steps:

1. The Hanford wells database was queried using the "WIDS and Wells MapOptix 6.3" interface (http://gisweb.rl.gov/mox6/heiq.cfm). These spatial queries varied from a 0.3 - to $10-\mathrm{km}$ (0.2- to 6.2-mi) radius surrounding a given site location. A map showing the station location and well query area was extracted and printed as a pdf file for incorporation into a base map using Adobe Illustrator $^{\mathrm{TM} 1}$.

2. The surface of the basalt structure contour map in Thorne et al. (2006, Figure 5.13) was examined to obtain the approximate elevation of basalt beneath each site and to estimate the approximate depth to basalt at each station. The list of wells/boreholes was filtered to remove wells/boreholes that most likely did not penetrate to the basalt surface.

3. Additional wells/boreholes were added to the list based on the "Inventory of boreholes that penetrate the uppermost basalt unit on the Hanford Site" (DOE 1988, Table 1.6-1) and the "Location map for boreholes used in Basalt Waste Isolation Project studies" (DOE 1988, Figure 1.6-2).

\footnotetext{
${ }^{\mathrm{TM}}$ EarthVision is a registered trademark of Dynamic Graphics, Inc., Alameda, California.

${ }^{\text {TM1 }}$ Illustrator is a trademark of Adobe Systems Incorporated, Seattle, Washington.
} 
4. Well information (e.g., location, elevation, drill depth) for the selected wells/boreholes was extracted from the Well Information and Data Lookup application (http://prc.rl.gov/widl/) and incorporated into an Excel ${ }^{\circledR}$ spreadsheet for each station.

5. Geologic contact data (contact elevation, contact depth, and/or thickness) from a variety of sources (e.g., Landon 1985; Thorne et al. 2006) were incorporated into the spreadsheet.

6. The elevation to the top of the basalt was estimated from available structure contour maps (e.g., Thorne et al. 2006; Last et al. 2009a, 2009b), and a depth to basalt calculated from the station elevation. The estimated depth to basalt was compared to contact information derived from nearby wells and a basalt contact depth was selected.

7. Contact depths for the suprabasalt sediments were estimated in a similar fashion where suitable structure contour maps were available (e.g., H2E and H2W). At other locations, the contact depths for suprabasalt sediment were derived from nearby boreholes.

8. Contact depths for the Saddle Mountains Basalt and interbeds were generally calculated using the average thickness of the individual flow and interbeds from the closest most representative deep boreholes.

9. Stratigraphic profiles were graphically constructed based on guidance provided by Lanigan et al. (2010).

For seismograph stations located off the Hanford Site (i.e., CCRK, DDRF, FHE, PHIN, TUCA, and WOLL) the general methodology was similar, but relied on the Washington State Well Log Viewer (http://apps.ecy.wa.gov/welllog/index.asp) for well location information and well logs, the Washington Interactive Geologic Map (https://fortress.wa.gov/dnr/geology/?Theme=wigm) for surface geologic coverage, and the Geologic Framework Mapper (http://or.water.usgs.gov/proj/cpras/index.html) for the major basalt formation contact elevations after Burns et al. (2011). Structure contour and isopach maps from Lindsey et al. (2009) were also consulted for sites in Franklin or Grant counties (i.e., DDRF, FHE, and WOLL).

The deep stratigraphic profiles (e.g., those extending to the crystalline basement) were created by scaling the shallower (post-Wanapum Basalt) stratigraphy and then extending the profile using stratigraphic top-contact data extracted from the solid Earth geologic model developed by Thorne et al. (in press). Thorne et al. examined two different conceptual models for the thickness of the Pre-Miocene sediments and top of the crystalline basement, but ultimately gave preference to the deep basement conceptual model (based in part on Glover's 1985 interpretation).

\subsection{Stratigraphic Profiles}

The stratigraphic profiles for each site are shown in Plates 1 through 20 in Appendix A. General descriptions of the stratigraphic units used in this study are listed in Table 2. The depth and thickness of the major stratigraphic units at each Hanford Site seismometer station and reference location are summarized in Table 3 and Table 4, respectively. The depth and thickness of stratigraphic units beneath the regional three-component broadband seismometer stations are summarized in Table 5.

\footnotetext{
${ }^{\circledR}$ Excel is a registered trademark of Microsoft Corporation, Redmond, Washington.
} 
Table 2. General description of stratigraphic units used in this report.

\begin{tabular}{|c|c|c|}
\hline Stratigraphic Unit & $\begin{array}{l}\text { Symbol } \\
\text { Used in } \\
\text { Tables } \\
\text { and } \\
\text { Plates }\end{array}$ & General Description \\
\hline Backfill & $\mathrm{Bf}$ & $\begin{array}{l}\text { Poorly sorted, massive, gravel, sand, and silt removed from and subsequently } \\
\text { returned to excavations. }\end{array}$ \\
\hline $\begin{array}{l}\text { Holocene } \\
\text { deposits, sand }\end{array}$ & HDs & $\begin{array}{l}\text { Medium- to fine-grained massive to weakly laminated eolian sand to silty sand, } \\
\text { equivalent to the fine-grained, massive, well-sorted and medium-grained cross- } \\
\text { bedded, well-sorted Holocene deposits described by DOE-RL (2002). }\end{array}$ \\
\hline $\begin{array}{l}\text { Hanford } \\
\text { formation, unit } 1\end{array}$ & $\mathrm{H} 1$ & $\begin{array}{l}\text { Upper gravel-dominated sequence, consisting of high-energy Ice Age flood deposits, } \\
\text { which in places grades upward into a mix of sandy and gravelly sediments. } \\
\text { Generally contains a high percentage of subangular basaltic clasts. Equivalent to } \\
\text { Lindsey et al. (2000) Unit H1a and Unit H1. }\end{array}$ \\
\hline $\begin{array}{l}\text { Hanford } \\
\text { formation, Unit } 2\end{array}$ & $\mathrm{H} 2$ & $\begin{array}{l}\text { Middle sand-dominated sequence, consisting of moderate- to high-energy Ice Age } \\
\text { flood deposits consisting of graded sandy and silty sediments often characterized as } \\
\text { basaltic, salt-and-pepper sand. Equivalent to Lindsey et al. (2000) Unit H2. }\end{array}$ \\
\hline $\begin{array}{l}\text { Hanford } \\
\text { formation, Unit } 3\end{array}$ & $\mathrm{H} 3$ & $\begin{array}{l}\text { Lower gravel-dominated sequence, consisting of high-energy Ice Age flood deposits } \\
\text { containing a high percentage of subangular basaltic clasts, equivalent to Unit } 3 \text { of } \\
\text { Lindsey et al. (1994) and Unit H3 of Lindsey et al. (2000). The base of this unit } \\
\text { includes some fine-grained materials equivalent to Lindsey et al. (2000) Unit H4. }\end{array}$ \\
\hline $\begin{array}{l}\text { Cold Creek Unit - } \\
\text { silt dominated }\end{array}$ & $\mathrm{CCUz}$ & $\begin{array}{l}\text { Fine sand, silt, and/or clay, laminated to massive, often characterized as very } \\
\text { micaceous, oxidized, and containing pedogenic calcium carbonate, with high natural } \\
\text { gamma activity. It is equivalent to the early "Palouse Soil" of Brown }(1959,1960) \text {, } \\
\text { a portion of the "locally derived subunit" of the Plio-Pleistocene Unit of Lindsey } \\
\text { et al. (1994), and the fine-grained, laminated to massive facies association of the } \\
\text { Cold Creek Unit of DOE-RL (2002). }\end{array}$ \\
\hline $\begin{array}{l}\text { Cold Creek Unit - } \\
\text { calcic }\end{array}$ & $\mathrm{CCUc}$ & $\begin{array}{l}\text { Pedogenic calcium carbonate-cemented clay, silt, sand, and/or gravel, equivalent to } \\
\text { the Caliche of Brown }(1959,1960) \text {, a portion of the "locally derived subunit" of the } \\
\text { Plio-Pleistocene Unit of Lindsey et al. (1994) and the coarse- to fine-grained, } \\
\text { carbonate-cemented facies association of the Cold Creek Unit of DOE-RL (2002). }\end{array}$ \\
\hline $\begin{array}{l}\text { Cold Creek Unit - } \\
\text { gravel dominated }\end{array}$ & $\mathrm{CCUg}$ & $\begin{array}{l}\text { Equivalent to the coarse-grained, multilithic facies of the Cold Creek Unit of DOE- } \\
\text { RL ( } 2002) \text { consisting of rounded, quartzose to gneissic, clast-supported pebble- to } \\
\text { cobble- size gravel with quartzo-feldspathic sand matrix. }\end{array}$ \\
\hline $\begin{array}{l}\text { Cold Creek Unit - } \\
\text { colluvium }\end{array}$ & CCUa & $\begin{array}{l}\text { Equivalent to the coarse-grained, angular, basaltic lithofacies of the Cold Creek Unit } \\
\text { of DOE-RL (2002) consisting mostly of angular, clast-to-matrix-supported, basaltic } \\
\text { gravel in poorly sorted mixture of sand and silt, with calcic paleosols locally present. }\end{array}$ \\
\hline $\begin{array}{l}\text { Ringold } \\
\text { Formation } \\
\text { member of Taylor } \\
\text { Flat [Upper } \\
\text { Ringold] }\end{array}$ & Rtf & $\begin{array}{l}\text { Interstratified deposits of fine-grained fluvial sand and silty overbank-paleosol } \\
\text { deposits (Lindsey 1995). }\end{array}$ \\
\hline $\begin{array}{l}\text { Ringold } \\
\text { Formation } \\
\text { member of } \\
\text { Wooded Island - } \\
\text { Unit E }\end{array}$ & Rwie & $\begin{array}{l}\text { Fluvial clast- and matrix-supported well-rounded pebble to cobble gravel of mixed } \\
\text { lithologies, in a fine to coarse sand matrix (Lindsey 1995). Cementation varies from } \\
\text { poor to well indurated, generally increasing with depth. }\end{array}$ \\
\hline
\end{tabular}


Table 2. (contd)

\begin{tabular}{|c|c|c|}
\hline Stratigraphic Unit & $\begin{array}{l}\text { Symbol } \\
\text { Used in } \\
\text { Tables } \\
\text { and } \\
\text { Plates }\end{array}$ & General Description \\
\hline $\begin{array}{l}\text { Ringold } \\
\text { Formation } \\
\text { member of } \\
\text { Wooded Island - } \\
\text { Fine unit between } \\
\text { E and C [Ringold } \\
\text { Upper Mud, } \\
\text { RUM] }\end{array}$ & Rwifec & $\begin{array}{l}\text { Fine-grained overbank and paleosol deposits that vertically separate Lindsey's } \\
\text { (1995) Unit C from overlying Unit E in the eastern part of the Hanford Site. }\end{array}$ \\
\hline $\begin{array}{l}\text { Ringold } \\
\text { Formation } \\
\text { member of } \\
\text { Wooded Island - } \\
\text { Unit C }\end{array}$ & Rwic & $\begin{array}{l}\text { Similar to Unit E (Rwie). Fluvial clast- and matrix-supported well-rounded pebble } \\
\text { to cobble gravel of mixed lithologies, in a fine to coarse sand matrix (Lindsey 1995). } \\
\text { Cementation generally increases with depth. }\end{array}$ \\
\hline $\begin{array}{l}\text { Ringold } \\
\text { Formation } \\
\text { member of } \\
\text { Wooded Island - } \\
\text { Fine unit between } \\
C \text { and } B\end{array}$ & Rwifcb & $\begin{array}{l}\text { Fine-grained overbank and paleosol deposits that vertically separate Lindsey's } \\
\text { (1995) Unit B from overlying Unit C in the eastern part of the Hanford Site. }\end{array}$ \\
\hline $\begin{array}{l}\text { Ringold } \\
\text { Formation } \\
\text { member of } \\
\text { Wooded Island - } \\
\text { Unit B }\end{array}$ & Rwib & $\begin{array}{l}\text { Similar to Unit E (Rwie). Fluvial clast- and matrix-supported well-rounded pebble } \\
\text { to cobble gravel of mixed lithologies, in a fine to coarse sand matrix (Lindsey 1995). } \\
\text { Cementation generally increases with depth. }\end{array}$ \\
\hline $\begin{array}{l}\text { Ringold } \\
\text { Formation - lower } \\
\text { mud }\end{array}$ & $\mathrm{Rlm}$ & $\begin{array}{l}\text { Fine-grained deposits consisting of stratified clay, silt, and sand (Lindsey 1995). } \\
\text { Primarily consists of lacustrine silt and clay, overlying a well-developed paleosol } \\
\text { noted beneath 200-West Area (Bjornstad 1984). }\end{array}$ \\
\hline $\begin{array}{l}\text { Ringold } \\
\text { Formation } \\
\text { member of } \\
\text { Wooded Island - } \\
\text { Unit A }\end{array}$ & Rwia & $\begin{array}{l}\text { Similar to Unit E (Rwie) (Lindsey 1995). Generally described as a conglomerate } \\
\text { with clasts of mixed lithologies and minor basalt in a silty sand matrix intercalated } \\
\text { with beds of sand and silt. The sediments are strongly cemented with silica or iron } \\
\text { oxide in places. }\end{array}$ \\
\hline $\begin{array}{l}\text { Saddle Mountains } \\
\text { Basalt, Ice Harbor } \\
\text { Member }\end{array}$ & $\mathrm{Ti}$ & $\begin{array}{l}\text { Tholeiitic flood-basalt. Consists of two thick flows, separated by a deposit of tephra } \\
\text { associated with several thin, discontinuous flows (Swanson et al. 1979). The lower } \\
\text { flow is termed the Martindale flow, while the upper flow is termed the Goose Island } \\
\text { flow. }\end{array}$ \\
\hline $\begin{array}{l}\text { Ellensburg } \\
\text { Formation, Levy } \\
\text { interbed }\end{array}$ & Tell & Tuffaceous sandstone to siltstone (Myers and Price, eds. 1981, pp. 3-37). \\
\hline $\begin{array}{l}\text { Saddle Mountains } \\
\text { Basalt, Elephant } \\
\text { Mountain Member }\end{array}$ & Tem & $\begin{array}{l}\text { Tholeiitic flood-basalt. Consists of at least two flows (Ward Gap and Elephant } \\
\text { Mountain), described as medium- to fine-grained with abundant microphenocrysts of } \\
\text { plagioclase, with transitional to normal magnetic polarity (DOE 1988, pp. 1.2-39). }\end{array}$ \\
\hline
\end{tabular}


Table 2. (contd)

\begin{tabular}{|c|c|c|}
\hline Stratigraphic Unit & $\begin{array}{l}\text { Symbol } \\
\text { Used in } \\
\text { Tables } \\
\text { and } \\
\text { Plates }\end{array}$ & General Description \\
\hline $\begin{array}{l}\text { Ellensburg } \\
\text { Formation, } \\
\text { Rattlesnake Ridge } \\
\text { interbed }\end{array}$ & Telr & $\begin{array}{l}\text { Various lithologies and textures ranging from clay or tuffaceous siltstone to } \\
\text { micaceous-arkosic sandstone and/or conglomerate, with plutonic and metamorphic } \\
\text { clasts (Myers and Price, eds. 1981, pp. 3-37) }\end{array}$ \\
\hline $\begin{array}{l}\text { Saddle Mountains } \\
\text { Basalt, Pomona } \\
\text { Member }\end{array}$ & $\mathrm{Tp}$ & $\begin{array}{l}\text { Tholeiitic flood-basalt. Consists of a single flow with a relatively uniform fine- } \\
\text { grained to glassy texture with wedge-shaped plagioclase phenocrysts and rare } \\
\text { olivine, and has reversed magnetic polarity (DOE 1988, pp. 1.2-38). }\end{array}$ \\
\hline $\begin{array}{l}\text { Ellensburg } \\
\text { Formation, Selah } \\
\text { interbed }\end{array}$ & Tels & $\begin{array}{l}\text { Variable mixture of silty or sandy, vitric tuff, arkosic sands, tuffaceous clays, and } \\
\text { locally thin stringer of predominantly basaltic gravel (Myers and Price, eds. 1981, } \\
\text { pp. 3-37) }\end{array}$ \\
\hline $\begin{array}{l}\text { Saddle Mountains } \\
\text { Basalt, Esquatzel } \\
\text { Member (Te) }\end{array}$ & $\mathrm{Te}$ & $\begin{array}{l}\text { Tholeiitic flood-basalt. Consists of one flow (occasionally two flow lobes) with } \\
\text { normal magnetic polarity and plagioclase phyric to glomerophyric texture, } \\
\text { containing microphenocrysts of clinopyroxene (DOE 1988, pp. 1.2-38). }\end{array}$ \\
\hline $\begin{array}{l}\text { Ellensburg } \\
\text { Formation, Cold } \\
\text { Creek interbed }\end{array}$ & Telc & $\begin{array}{l}\text { Consists of tuffaceous siltstone to claystone, fine-grained tuffaceous sandstone, } \\
\text { coarser sandstone and conglomerate depending on the relationship to bounding } \\
\text { basalt flows (Myers and Price, eds. 1981, pp. 3-32). Myers and Price, eds. (1981, } \\
\text { pp. 3-32) recognized three separate intervals: the Asotin-Esquatzel interval, the } \\
\text { Umatilla-Esquatzel interval, and the Umatilla-Asotin interval (sometimes referred to } \\
\text { as an unnamed interbed). }\end{array}$ \\
\hline $\begin{array}{l}\text { Saddle Mountains } \\
\text { Basalt, Asotin } \\
\text { Member }\end{array}$ & $\mathrm{Ta}$ & $\begin{array}{l}\text { Tholeiitic flood-basalt. Consists of one flow with fine-grained and glassy to ophitic } \\
\text { texture and abundant olivine but sparse plagioclase, and normal magnetic polarity } \\
\text { (DOE 1988, pp. 1.2-37). }\end{array}$ \\
\hline $\begin{array}{l}\text { Saddle Mountains } \\
\text { Basalt, Umatilla } \\
\text { Member }\end{array}$ & $\mathrm{Tu}$ & $\begin{array}{l}\text { Tholeiitic flood-basalt. Consists of up to several flows, informally divided into two } \\
\text { units, with fine-grained to glassy texture with rare phenocrysts of plagioclase to } \\
\text { olivine and has normal magnetic polarity (DOE 1988, pp. 1.2-34). }\end{array}$ \\
\hline $\begin{array}{l}\text { Ellensburg } \\
\text { Formation, } \\
\text { Mabton interbed }\end{array}$ & Telm & $\begin{array}{l}\text { Consists of 1) well-indurated, lapilli tuffstone, 2) fine-grained, tuffaceous, clayey } \\
\text { quartzitic sandstone, 3) quartzitic to arkosic sandstone, with interlayered tuffaceous } \\
\text { sandstones and siltstones, and 4) a thin basal silty clay (Myers and Price, eds. 1981, } \\
\text { pp. 3-32). }\end{array}$ \\
\hline $\begin{array}{l}\text { Wanapum Basalt, } \\
\text { Priest Rapids } \\
\text { Member }\end{array}$ & Tpr & $\begin{array}{l}\text { Tholeiitic flood-basalt. Informally subdivided into two units that both have reversed } \\
\text { magnetic polarity. The youngest unit, the Lolo flow, contains small olivine } \\
\text { phenocrysts and rare glomerocrysts or phenocrysts of plagioclase (DOE 1988, } \\
\text { pp. 1.2-33). }\end{array}$ \\
\hline $\begin{array}{l}\text { Grande Ronde } \\
\text { Basalt, } \\
\text { Undifferentiated }\end{array}$ & Tgr & Fine-grained, aphyric, tholeiitic flood-basalt (Reidel et al. 1989a). \\
\hline $\begin{array}{l}\text { Pre-Miocene } \\
\text { Sediments }\end{array}$ & & $\begin{array}{l}\text { Tertiary continental sedimentary rock (Campbell 1989; Reidel et al. 1989b), perhaps } \\
\text { consisting of thick sequences of arkose, volcaniclastic rocks, and coal. }{ }^{(a)}\end{array}$ \\
\hline $\begin{array}{l}\text { Crystalline } \\
\text { Basement }\end{array}$ & & $\begin{array}{l}\text { Perhaps consisting of Precambrian Belt Supergroup sedimentary rocks and } \\
\text { metamorphosed Cretaceous granites. }{ }^{\text {(a) }}\end{array}$ \\
\hline
\end{tabular}

(a) Geology of Washington - Columbia Basin. An online report available at http://www.dnr.wa.gov/researchscience/topics/geologyofwashington/pages/columbia.aspx 
Table 3. Estimated depth ( $\mathrm{ft}$ ) to top contact and thickness ( $\mathrm{ft}$ ) of stratigraphic units beneath selected Hanford Site seismometer stations.

\begin{tabular}{|c|c|c|c|c|c|c|c|c|}
\hline Strat. Unit & $\begin{array}{c}\text { H1K } \\
\text { (Plate 1) } \\
\text { (Plate 1a) }\end{array}$ & $\begin{array}{c}\mathrm{H} 2 \mathrm{E} \\
\text { (Plate 2) } \\
\text { (Plate 2a) }\end{array}$ & $\begin{array}{c}\mathrm{H} 2 \mathrm{~W} \\
\text { (Plate 3) } \\
\text { (Plate 3a) }\end{array}$ & $\begin{array}{c}\text { H3A } \\
\text { (Plate 4) } \\
\text { (Plate 4a) }\end{array}$ & $\begin{array}{c}\text { H4A } \\
\text { (Plate 5) } \\
\text { (Plate 5a) }\end{array}$ & $\begin{array}{c}\text { HAWA } \\
\text { (Plate 6) } \\
\text { (Plate 6a) }\end{array}$ & $\begin{array}{c}\text { WIA/ } \\
\text { WIB } \\
\text { (Plate 17) }\end{array}$ & $\begin{array}{c}\text { WIXX } \\
\text { (Plate 18) }\end{array}$ \\
\hline $\begin{array}{l}\text { Holocene } \\
\text { Undiff. }\end{array}$ & NP & & NP & NP & & $0 / 12$ & & $0 / 12$ \\
\hline $\begin{array}{l}\text { Hanford } \\
\text { Undiff. }\end{array}$ & 0 / 69 & & & & $0 / 195$ & NP & $0 / 77$ & 12 / 33 \\
\hline $\mathrm{H} 1$ & & $0 / 10$ & $0 / 43$ & $0 / 62$ & & NP & & \\
\hline $\mathrm{H} 2$ & & $10 / 249$ & $43 / 49$ & NP & & NP & & \\
\hline $\mathrm{H} 3$ & & $259 / 7$ & NP & NP & & NP & & \\
\hline CCUz & NP & NP & $92 / 16$ & NP & NP & NP & NP & NP \\
\hline CCUc & NP & NP & $108 / 36$ & NP & NP & $\mathrm{NP}$ & NP & $\mathrm{NP}$ \\
\hline CCUg & NP & $266 / 59$ & NP & NP & NP & NP & NP & NP \\
\hline CCUa & NP & NP & $\mathrm{NP}$ & NP & NP & $12 / 16^{\mathrm{a}}$ & NP & NP \\
\hline Rtf & NP & NP & NP & NP & NP & NP & NP & NP \\
\hline Rwie & $69 / 129$ & NP & $144 / 289$ & $62 / 11$ & $195 / 150$ & NP & $77 / 58$ & $45 / 47$ \\
\hline Rwifec & $198 / 168$ & NP & NP & NP & NP & NP & 135 / 32 & NP \\
\hline Rwic & $?$ & NP & NP & NP & NP & $\mathrm{NP}$ & NP & NP \\
\hline Rwifcb & $?$ & NP & NP & $73 / 48$ & NP & NP & NP & NP \\
\hline Rwib & $366 / 81$ & NP & NP & $121 / 23$ & NP & $\mathrm{NP}$ & $167 / 31$ & NP \\
\hline $\mathrm{Rlm}$ & $447 / 159$ & NP & $433 / 53$ & $144 / 43$ & $345 / 132$ & $\mathrm{NP}$ & $198 / 19$ & $92 / 6$ \\
\hline Rwia & $606 / 90$ & 325 / 29 & 486 / 52 & NP & $477 / 125$ & $\mathrm{NP}$ & NP & $98 / 33$ \\
\hline $\begin{array}{l}\mathrm{Ti}- \\
\text { Goose } \\
\text { Island } \\
\text { Flow }\end{array}$ & NP & NP & NP & NP & NP & NP & $217 / 34$ & $131 / 34$ \\
\hline $\begin{array}{l}\mathrm{Ti}- \\
\text { Matindale } \\
\text { Flow }\end{array}$ & NP & NP & NP & 187 / 66 & NP & NP & $251 / 52$ & 165 / 52 \\
\hline Tell & NP & NP & NP & $253 / 17$ & NP & NP & $303 / 26$ & $217 / 26$ \\
\hline $\begin{array}{l}\text { Tem- } \\
\text { Ward Gap } \\
\text { flow }\end{array}$ & NP & NP & NP & $270 / 46$ & 602 / 32 & NP & $329 / 13$ & $243 / 13$ \\
\hline $\begin{array}{l}\text { Tem- } \\
\text { Elephant } \\
\text { Mtn. flow }\end{array}$ & $696 / 110$ & 354 / 111 & $538 / 94$ & $316 / 105$ & 634 / 78 & 28 / 102 & $342 / 114$ & $256 / 114$ \\
\hline Telr & $806 / 47$ & $465 / 45$ & $632 / 95$ & $421 / 28$ & $712 / 96$ & $130 / 43$ & $456 / 22$ & $370 / 22$ \\
\hline $\mathrm{Tp}$ & $853 / 175$ & $510 / 198$ & $727 / 152$ & 449 / 174 & $808 / 112$ & $173 / 155$ & $478 / 141$ & $392 / 141$ \\
\hline Tels & $1028 / 51$ & 708 / 22 & 879 / 59 & $623 / 2$ & $920 / 28$ & $328 / 5$ & $619 / 2$ & $533 / 2$ \\
\hline $\mathrm{Te}$ & 1079 / 52 & $730 / 95$ & $938 / 103$ & $625 / 100$ & $948 / 112$ & $333 / 86$ & $621 / 118$ & $535 / 118$ \\
\hline Telc & $1131 / 3$ & 825 / 98 & $1041 / 73$ & $725 / 70$ & $1060 / 90$ & $419 / 3$ & $739 / 48$ & 653 / 48 \\
\hline $\mathrm{Ta}$ & 1134 / $97 ?$ & NP & NP & NP & NP & NP & NP & NP \\
\hline $\mathrm{Tu}$ & $\begin{array}{c}1231 ? / \\
198 ?\end{array}$ & $923 / 157$ & $\begin{array}{c}1114 / \\
217\end{array}$ & 795 / 267 & $\begin{array}{c}1150 / \\
195\end{array}$ & $422 / 268$ & 787 / 247 & $701 / 247$ \\
\hline Telm & 1429 / 59 & 1080 / 98 & $\begin{array}{c}1331 / \\
126\end{array}$ & 1062 / 38 & $\begin{array}{c}1345 / \\
111\end{array}$ & 690 / 57 & 1034 / 32 & 948 / 32 \\
\hline $\begin{array}{l}\text { Wanapum } \\
\text { Basalt }\end{array}$ & $\begin{array}{c}1488 / \\
1093\end{array}$ & $\begin{array}{c}1178 / \\
1029\end{array}$ & $\begin{array}{c}1457 / \\
1193\end{array}$ & $\begin{array}{l}1100 / \\
1001\end{array}$ & $\begin{array}{c}1456 / \\
1034\end{array}$ & $\begin{array}{l}747 / \\
1090\end{array}$ & 1066 / ? & 980 / ? \\
\hline $\begin{array}{l}\text { Grande } \\
\text { Ronde } \\
\text { Basalt }\end{array}$ & $\begin{array}{c}2581 / \\
8555\end{array}$ & $\begin{array}{c}2207 / \\
7628\end{array}$ & $\begin{array}{c}2650 / \\
8262\end{array}$ & $\begin{array}{c}2101 / \\
5427\end{array}$ & $\begin{array}{c}2490 / \\
4932\end{array}$ & $\begin{array}{c}1837 / \\
7222\end{array}$ & & \\
\hline
\end{tabular}


Table 3. (contd)

\begin{tabular}{|c|c|c|c|c|c|c|c|c|}
\hline Strat. Unit & $\begin{array}{c}\text { H1K } \\
\text { (Plate 1) } \\
\text { (Plate 1a) }\end{array}$ & $\begin{array}{c}\text { H2E } \\
\text { (Plate 2) } \\
\text { (Plate 2a) }\end{array}$ & $\begin{array}{c}\text { H2W } \\
\text { (Plate 3) } \\
\text { (Plate 3a) }\end{array}$ & $\begin{array}{c}\text { H3A } \\
\text { (Plate 4) } \\
\text { (Plate 4a) }\end{array}$ & $\begin{array}{c}\text { H4A } \\
\text { (Plate 5) } \\
\text { (Plate 5a) }\end{array}$ & $\begin{array}{c}\text { HAWA } \\
\text { (Plate 6) } \\
\text { (Plate 6a) }\end{array}$ & $\begin{array}{c}\text { WIA/ } \\
\text { WIB } \\
\text { (Plate 17) }\end{array}$ & $\begin{array}{c}\text { WIXX } \\
\text { (Plate 18) }\end{array}$ \\
\hline $\begin{array}{l}\text { Pre- } \\
\text { Miocene } \\
\text { Sediments }\end{array}$ & $\begin{array}{c}11136 / \\
17863\end{array}$ & $\begin{array}{l}9835 / \\
20644\end{array}$ & $\begin{array}{l}10912 / \\
20803\end{array}$ & $\begin{array}{l}7528 / \\
16705\end{array}$ & $\begin{array}{l}7422 / \\
19416\end{array}$ & $\begin{array}{l}9059 / \\
21134\end{array}$ & & \\
\hline $\begin{array}{l}\text { Crystalline } \\
\text { Basement* }\end{array}$ & 28999 / ? & $30479 / ?$ & $31715 / ?$ & $24233 / ?$ & $26838 / ?$ & $30293 / ?$ & & \\
\hline \multicolumn{9}{|c|}{$\begin{array}{l}\text { (a) Described as cemented gravel, and interpreted to be cemented talus/slope wash equivalent to the C } \\
\text { Unit. } \\
\mathrm{D} / \mathrm{T}=\text { depth in feet below ground surface/thickness in feet (to convert to meters, multiply by } 0.3048 \text { ) } \\
\text { Undiff. = undifferentiated } \\
\mathrm{NP}=\text { Inferred to be not present } \\
?=\text { Unknown or not determined for this study }\end{array}$} \\
\hline
\end{tabular}

Table 4. Estimated depth (ft) to top contact and thickness ( $\mathrm{ft}$ ) of stratigraphic units beneath selected reference locations.

\begin{tabular}{|c|c|c|c|c|c|}
\hline Stratigraphic Unit & $\begin{array}{c}\text { A1 (WTP) } \\
\text { (Plate 7) } \\
\text { (Plate 7a) }\end{array}$ & $\begin{array}{c}\text { B (200 W \& } \\
\text { H2WO) } \\
\text { (Plate 8) } \\
\text { (Plate 8a) }\end{array}$ & $\begin{array}{l}\text { C (CGS) } \\
\text { (Plate 9) } \\
\text { (Plate 9a) }\end{array}$ & $\begin{array}{c}\mathrm{D}(105-\mathrm{B}) \\
\text { (Plate 10) } \\
\text { (Plate 10a) }\end{array}$ & $\begin{array}{c}\mathrm{E}(300) \\
\text { (Plate 11) } \\
\text { (Plate 11a) }\end{array}$ \\
\hline Holocene Undiff. & $0 / 9$ & $\mathrm{NP}$ & $\mathrm{NP}$ & $\mathrm{NP}$ & NP \\
\hline Hanford Undiff. & & & $0 / 43$ & $0 / 89$ & \\
\hline $\mathrm{H} 1$ & NP & $0 / 36$ & NP & & $0 / 60$ \\
\hline $\mathrm{H} 2$ & $9 / 151$ & $36 / 76$ & $\mathrm{NP}$ & & $\mathrm{NP}$ \\
\hline $\mathrm{H} 3$ & $160 / 90$ & NP & & & NP \\
\hline CCUz & NP & $112 / 6$ & NP & NP & NP \\
\hline CCUc & $\mathrm{NP}$ & $118 / 13$ & NP & NP & NP \\
\hline CCUg & $250 / 72$ & NP & NP & NP & NP \\
\hline CCUa & NP & NP & NP & NP & NP \\
\hline Rtf & NP & NP & NP & NP & NP \\
\hline Rwie & NP & $131 / 282$ & 43 / 207 & $89 / 96$ & $60 / 33$ \\
\hline Rwifec & NP & $\mathrm{NP}$ & $\mathrm{NP}$ & $185 / 108$ & $\mathrm{NP}$ \\
\hline Rwic & NP & NP & NP & $?$ & NP \\
\hline Rwifcb & NP & NP & $250 / 55$ & $?$ & $93 / 31$ \\
\hline Rwib & NP & NP & $305 / 111$ & $293 / 115$ & $124 / 26$ \\
\hline $\mathrm{R} \operatorname{lm}$ & NP & $413 / 37$ & $416 / 51$ & $408 / 205$ & $150 / 42$ \\
\hline Rwia & $322 / 60$ & $450 / 62$ & $467 / 58$ & $613 / 40$ & $\mathrm{NP}$ \\
\hline $\mathrm{Ti}$ & $\mathrm{NP}$ & $\mathrm{NP}$ & $\mathrm{NP}$ & $\mathrm{NP}$ & $192 / 72$ \\
\hline Tell & $\mathrm{NP}$ & NP & NP & NP & $264 / 19$ \\
\hline Tem - Ward Gap flow & NP & $\mathrm{NP}$ & $525 / 32$ & NP & $283 / 41$ \\
\hline $\begin{array}{l}\text { Tem - Elephant Mtn. } \\
\text { flow }\end{array}$ & $382 / 111$ & $512 / 97$ & $557 / 98$ & $653 / 117$ & $324 / 106$ \\
\hline Telr & $493 / 45$ & $609 / 90$ & $655 / 25$ & $770 / 47$ & $430 / 28$ \\
\hline $\mathrm{Tp}$ & $538 / 198$ & $699 / 148$ & $680 / 160$ & $817 / 176$ & $458 / 169$ \\
\hline Tels & $736 / 22$ & $847 / 68$ & $840 / 15$ & $993 / 50$ & $627 / 2$ \\
\hline $\mathrm{Te}$ & $758 / 95$ & $915 / 91$ & $855 / 110$ & $1043 / 64$ & $629 / 103$ \\
\hline Telc & $853 / 98$ & $1006 / 85$ & $965 / 44$ & $1107 / 4$ & $732 / 67$ \\
\hline
\end{tabular}


Table 4. (contd)

\begin{tabular}{|c|c|c|c|c|c|}
\hline Stratigraphic Unit & $\begin{array}{c}\text { A1 (WTP) } \\
\text { (Plate 7) } \\
\text { (Plate 7a) }\end{array}$ & $\begin{array}{l}\text { B (200 W \& } \\
\text { H2WO) } \\
\text { (Plate 8) } \\
\text { (Plate 8a) }\end{array}$ & $\begin{array}{c}\text { C (CGS) } \\
\text { (Plate 9) } \\
\text { (Plate 9a) }\end{array}$ & $\begin{array}{c}\text { D (105-B) } \\
\text { (Plate 10) } \\
\text { (Plate 10a) }\end{array}$ & $\begin{array}{c}\mathrm{E}(300) \\
\text { (Plate 11) } \\
\text { (Plate 11a) }\end{array}$ \\
\hline $\mathrm{Ta}$ & NP & NP & NP & $1111 / 81$ & NP \\
\hline Unnamed interbed & NP & NP & NP & $1192 / 8$ & NP \\
\hline $\mathrm{Tu}(\mathrm{s})-$ Sillusi flow & $951 / 49$ & $1091 / 52$ & & & \\
\hline Tu(u) - Umatilla flow & $1000 / 108$ & $1143 / 138$ & $1009 / 214$ & $1200 / 175$ & $799 / 264$ \\
\hline Telm & $1108 / 98$ & $1281 / 141$ & $1223 / 67$ & $1375 / 113$ & $1063 / 37$ \\
\hline Wanapum Basalt & $1206 / 1029$ & $1422 / 1163$ & $1290 / 1073$ & $1474 / 1265$ & $1100 / 996$ \\
\hline Grande Ronde Basalt & $2235 / 7326$ & $2585 / 8217$ & $2363 / 4631$ & $2739 / 8830$ & $2096 / 5418$ \\
\hline Pre-Miocene Sediments & $9561 / 20749$ & $10802 / 20768$ & 6994 / 19509 & $11569 / 17833$ & $7514 / 16786$ \\
\hline Crystalline Basement* & $30310 / ?$ & $31570 / ?$ & $26503 / ?$ & $29402 / ?$ & $24300 / ?$ \\
\hline \multicolumn{6}{|c|}{$\begin{array}{l}\mathrm{D} / \mathrm{T}=\text { depth in feet below ground surface/thickness in feet (to convert to meters, multiply by } 0.3048 \text { ) } \\
\text { Undiff. = undifferentiated } \\
\text { NP = Inferred to be not present } \\
?=\text { Unknown or not determined for this study } \\
* \text { Based on contacts from Paul Thorne email dated } 8-20-2013 \text {. }\end{array}$} \\
\hline
\end{tabular}

Table 5. Estimated depth ( $\mathrm{ft}$ ) to top contact and thickness ( $\mathrm{ft}$ ) of stratigraphic units beneath selected regional three-component broadband seismometer stations.

\begin{tabular}{|c|c|c|c|c|c|c|c|}
\hline Stratigraphic Unit & $\begin{array}{c}\text { CCRK } \\
\text { (Plate 12) }\end{array}$ & $\begin{array}{c}\text { DDRF } \\
\text { (Plate 13) }\end{array}$ & $\begin{array}{c}\text { FHE } \\
\text { (Plate 14) }\end{array}$ & $\begin{array}{c}\text { PHIN } \\
\text { (Plate 15) }\end{array}$ & $\begin{array}{c}\text { GBB } \\
\text { (Plate 16) }\end{array}$ & $\begin{array}{c}\text { WOLL } \\
\text { (Plate 19) }\end{array}$ & $\begin{array}{c}\text { TUCA } \\
\text { (Plate 20) }\end{array}$ \\
\hline $\begin{array}{l}\text { Undiff. Unconsolidated } \\
\text { Sediment (e.g. Loess) }\end{array}$ & $0 / 15$ & $0 / 2$ & $0 / 2$ & $0 / 3$ & NP & $0 / 12$ & $0 / 11$ \\
\hline Undiff. Clay & NP & NP & NP & $3 / 22$ & NP & NP & NP \\
\hline $\mathrm{Ti}$ & NP & $2 / 72$ & NP & NP & NP & NP & NP \\
\hline Tell & NP & $74 / 10$ & NP & NP & NP & NP & NP \\
\hline Tem & $15 / 56$ & $84 / 76$ & $2 / 124$ & $25 / 95$ & $0 / 50$ & NP & NP \\
\hline Telr & $71 / 83$ & $160 / 20$ & NP & $120 / 69$ & $50 / 11$ & NP & NP \\
\hline $\mathrm{Tp}$ & $154 / 116$ & $180 / 139$ & NP & $189 / 159$ & $61 / 108$ & NP & NP \\
\hline Tels & NP & $319 / 37$ & NP & $348 / 30$ & $169 / 22$ & NP & NP \\
\hline $\mathrm{Te}$ & $270 / 102$ & $356 / 84$ & NP & NP & $191 / 50$ & NP & NP \\
\hline Telc & NP & NP & NP & NP & NP & NP & NP \\
\hline $\mathrm{Ta}$ & NP & NP & NP & NP & $241 / 39$ & NP & NP \\
\hline Unnamed interbed & NP & NP & NP & NP & $280 / 4$ & NP & NP \\
\hline $\mathrm{Tu}$ & $372 / 276$ & NP & NP & $378 / 232$ & 284 / 164 & NP & NP \\
\hline Telm & $648 / 88$ & $440 / 25$ & $126 / 26$ & NP? & $448 / 138$ & NP & NP \\
\hline Wanapum Basalt & $736 / ?$ & $465 / ?$ & $152 / ?$ & $610 / ?$ & $586 / ?$ & $12 / 447$ & NP \\
\hline Grande Ronde Basalt & & & & & & 447 / ? & $11 / ?$ \\
\hline \multicolumn{8}{|c|}{$\begin{array}{l}\mathrm{D} / \mathrm{T}=\text { depth in feet below ground surface/thickness in feet (to convert to meters, multiply by } 0.3048 \text { ) } \\
\text { Undiff. = undifferentiated } \\
\mathrm{NP}=\text { Inferred to be not present }\end{array}$} \\
\hline
\end{tabular}




\subsection{Uncertainties}

A number of potential sources of error involve the site location, elevation, and interpreted stratigraphic contacts.

\subsection{Station/Site Location and Elevation}

There is some uncertainty about the published coordinates and elevation of some of the seismometer stations. The horizontal locations from different published sources (see Table 1) vary from just over $100 \mathrm{~m}(328 \mathrm{ft})$ to over $330 \mathrm{~m}(1,080 \mathrm{ft})$, and elevations vary by up to $70 \mathrm{~m}(230 \mathrm{ft})$. The accuracy of the

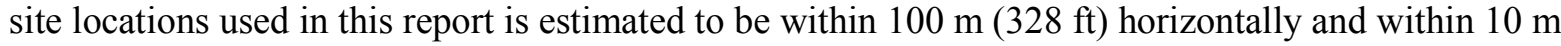
(33 ft) vertically. Uncertainty about the horizontal locations is not expected to have significant impacts on the stratigraphic profiles. However, uncertainty in the elevation of the stations could affect the interpreted depth (and thickness) of stratigraphic units (particularly the top of the basalt and suprabasalt sediments), leading to differences on the order of $10 \mathrm{~m}(33 \mathrm{ft})$.

\subsection{Interpreted Stratigraphic Contacts}

Stratigraphic contacts used in this report are based on interpretation of borehole data and samples made by a number of different individuals for different environmental programs, often using different stratigraphic nomenclature. Reidel and Chamness (2007) summarized some of the sources of uncertainty regarding the interpretation of stratigraphic contacts. Although their summary was aimed primarily at the suprabasalt sediments, similar sources of uncertainty also apply to contacts within and below the Saddle Mountains Basalt. These sources of uncertainty include 1) the quality of subsurface data, which is influenced by the drilling technique, the logging of the borehole, and sample collection; 2) subtle differences between some stratigraphic units that make identification of the stratigraphic contacts difficult; and 3) uncertainty in the spatial distribution and thickness of the stratigraphic units.

\subsection{Borehole Coverage}

The number and location of and distance to boreholes with reasonable stratigraphic interpretations also have a major effect on the uncertainty of the stratigraphic profiles - the farther away and the fewer the number of useful boreholes, the less confident the extrapolations are.

\subsection{Qualitative Estimates of Uncertainty for Each Site}

A qualitative assessment of the level of uncertainty (i.e., variation in depth and thickness) for each site is described below. Plates 1 through 20 (noted parenthetically in the following sections) are presented in Appendix A.

\subsubsection{Station H1K (Plates 1 and 1a)}

The nearest borehole (199-K-187) is located approximately $215 \mathrm{~m}(705 \mathrm{ft})$ away from this station, and provides good stratigraphic control down to the top of the Ringold Formation upper mud (Rwifec) 
(Hartman 2011). The stratigraphy for the lower portion of the Ringold Formation is extrapolated from the average thickness of stratigraphic units penetrated by two boreholes located 2.6 to $3.6 \mathrm{~km}$ (1.6 to $2.2 \mathrm{mi})$ away. The difference in interpreted thickness for these units ranged from $8.5 \mathrm{~m}(28 \mathrm{ft})$ to $43 \mathrm{~m}(141 \mathrm{ft})$.

The elevation of the top of the basalt was based on the structure contour map of the basalt surface provided by Thorne et al. (2006). The scale of this map and the $20-\mathrm{m}$ (65.5-ft) elevation contour interval relative to the estimated location and elevation of the seismometer station suggests that the contact elevation for the top of the basalt may be good to within about $10 \mathrm{~m}(33 \mathrm{ft})$. The stratigraphy of the Saddle Mountains Basalt and associated interbeds was extrapolated from the average thickness of stratigraphic units penetrated by three boreholes located 2.6 to $4 \mathrm{~km}$ (1.6 to $2.5 \mathrm{mi}$ ) away-all northeast of the station. Where multiple interpretations are available, the range in interpreted thicknesses for each of these units varied from 0.6 to $4.6 \mathrm{~m}$ ( 2 to $15 \mathrm{ft}$ ). Contact elevations for the top of the Saddle Mountains Basalt and the top of the Wanapum Basalt were also extracted from a large-scale solid Earth model developed by Thorne et al. (in press). The grid size for this model was pretty large $(80 \mathrm{~km} \times 120 \mathrm{~km})$ and the input data were relatively sparse, so these contact elevations were used primarily for comparison purposes, yielding differences of $6 \mathrm{~m}(20 \mathrm{ft})$ to $13 \mathrm{~m}(44 \mathrm{ft})$.

The deep stratigraphy, below the top of the Wanapum Basalt, is based on contact elevations extracted from Thorne et al.'s (in press) large-scale solid Earth model. One of the greatest sources of uncertainty is the thickness of the pre-Miocene sediments and elevation of the top of the crystalline basement. Thorne examined two different conceptual models with the top of the crystalline basement varying by $4,038 \mathrm{~m}$ $(13,250 \mathrm{ft})$.

\subsubsection{Station H2E (Plates 2 and 2a)}

The stratigraphy of the suprabasalt sediments and the contact for the top of the basalt were extrapolated from structure contour maps provided by Last et al. (2009b). The scale of these maps and the $3-\mathrm{m}(10-\mathrm{ft})$ elevation contour interval relative to the estimated location of the station suggests that the contact elevation for the top of the basalt and suprabasalt sediments may be good to within about $3 \mathrm{~m}$ $(10 \mathrm{ft})$. Taking into account the uncertainty about the elevation of the station (perhaps as much as $23 \mathrm{~m}$ lower), this may increase the potential uncertainty for the stratigraphic contacts to about $25 \mathrm{~m}$ ( $82 \mathrm{ft}$ ).

The stratigraphy of the Saddle Mountains Basalt and associated interbeds was extrapolated from the average thicknesses of stratigraphic units interpreted from four boreholes (C4993, C4996, C4997, and C4998 in Barnett et al. 2007) located 2.3 to $2.5 \mathrm{~km}$ (1.4 to $1.5 \mathrm{mi})$ away -all east of the station. The difference in the interpreted thicknesses for each of these units ranged from 0.3 to $7 \mathrm{~m}$ ( 1 to $23 \mathrm{ft}$ ). Model contact elevations extracted from Thorne et al.'s (in press) solid Earth model differed by $10 \mathrm{~m}$ (34 ft) to $12 \mathrm{~m}(40 \mathrm{ft})$.

Two different conceptual models examined by Thorne et al. (in press) yielded a difference in the solid Earth model output of 5,205 $\mathrm{m}(17,078 \mathrm{ft})$ for the top-contact elevation of the crystalline basement.

\subsubsection{Station H2W2006 (a.k.a. H2W; Plates 3 and 3a)}

The stratigraphy of the suprabasalt sediments and the contact for the top of the basalt was extrapolated from structure contour maps provided by Last et al. (2009a). The scale of these maps and 
the 3-m (10-ft) elevation contour interval relative to the estimated location of the station suggest that the estimated contact elevation for the top of the basalt and suprabasalt sediments may be good to within about $3 \mathrm{~m}(10 \mathrm{ft})$. Taking into account the uncertainty about the elevation of the station (perhaps as much as $72 \mathrm{~m}$ lower), this may increase the potential uncertainty to about $25 \mathrm{~m}(82 \mathrm{ft})$.

The stratigraphy of the Saddle Mountains Basalt and associated interbeds was extrapolated from the average thicknesses of stratigraphic units interpreted from three boreholes located 1 to $2 \mathrm{~km}(0.6$ to $1.2 \mathrm{mi}$ ) away - west, northwest, and north of the station. The difference in the interpreted thicknesses for each of these units ranged from 0.3 to $9 \mathrm{~m}$ ( 1 to $30 \mathrm{ft}$ ). Model contact elevations extracted from Thorne et al.'s (in press) solid Earth model differed by $8 \mathrm{~m}(27 \mathrm{ft})$ to $14 \mathrm{~m}(44 \mathrm{ft})$.

Two different conceptual models examined by Thorne et al. (in press) yielded a difference in the solid Earth model output of 4,552 $\mathrm{m}(14,934 \mathrm{ft})$ for the top-contact elevation of the crystalline basement.

\subsubsection{Station H3A (Plates 4 and 4a)}

The stratigraphy of the suprabasalt sediments was based on a borehole located about $100 \mathrm{~m}$ ( $328 \mathrm{ft})$ southwest of the station, as well as the structure contour map for the top of the Ringold Formation provided by the DOE Richland Operations Office (DOE-RL 2011, Figure 3-24). The scale of the Ringold Formation structure contour map and the $1.5-\mathrm{m}(5-\mathrm{ft})$ contour interval relative to the estimated location of the station suggests that the estimated contact elevation for the top of the Ringold Formation may be good

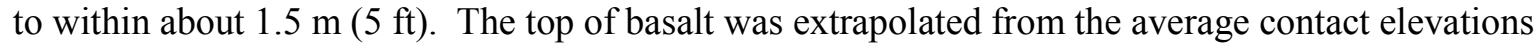
interpreted from three boreholes located 0.4 to $1.4 \mathrm{~km}(0.2$ to $0.9 \mathrm{mi})$ away. All interpreted elevations were within $6 \mathrm{~m}(20 \mathrm{ft})$, suggesting that the estimated contact elevation for the top of basalt may be good to within about $3 \mathrm{~m}(10 \mathrm{ft})$. Taking into account uncertainty regarding the elevation of the station (as much as $20 \mathrm{~m}$ lower), this may increase the potential uncertainty in the contact depths for the top of basalt and the suprabasalt sediments to about $20 \mathrm{~m}(65 \mathrm{ft})$.

The stratigraphy for the Saddle Mountains Basalt and associated interbeds was based on the distanceweighted average thickness from two boreholes located 1 to $3.5 \mathrm{~km}(0.6$ to $2 \mathrm{mi})$ away. The difference in the interpreted thicknesses for each of these stratigraphic units varied up to $13 \mathrm{~m}$ (43 ft). The model contact elevation for the top of the Saddle Mountains Basalt extracted from Thorne et al.'s (in press) solid Earth model differed by less than $1 \mathrm{~m}(2 \mathrm{ft})$; the contact elevation difference for the top of the Wanapum Basalt differed by $23 \mathrm{~m}(77 \mathrm{ft})$.

Two different conceptual models examined by Thorne et al. (in press) yielded a difference in the solid Earth model output of 4,115 m (13,502 ft) for the top-contact elevation of the crystalline basement.

\subsubsection{Station H4A (Plates 5 and 5a)}

The nearest borehole with documented stratigraphic interpretations is located approximately $340 \mathrm{~m}$ $(1,100 \mathrm{ft})$ northwest of the station, and it provides good stratigraphic control for the top of basalt and suprabasalt sediments. Another borehole located $480 \mathrm{~m}$ (1,500 ft) to the northwest has interpreted top of basalt elevations of up to $24 \mathrm{~m}(79 \mathrm{ft})$ lower.

The stratigraphy for the Saddle Mountains Basalt and associated interbeds was based on the

interpreted contacts from the borehole located $480 \mathrm{~m}(1,500 \mathrm{ft})$ away. Other deep boreholes that penetrate 
the Saddle Mountains Basalt are located more than $5 \mathrm{~km}$ (3 mi) away and have interpreted thicknesses for the different strata that vary by as much as $82 \mathrm{~m}$ (269 ft). The model contact elevation for the top of the Saddle Mountains Basalt extracted from Thorne et al.'s (in press) solid Earth model differed by about $5 \mathrm{~m}$ $(15 \mathrm{ft})$; the contact elevation difference for the top of the Wanapum Basalt differed by $7 \mathrm{~m}(22 \mathrm{ft})$.

Two different conceptual models examined by Thorne et al. (in press) yielded a difference in the solid Earth model output of 4,335 m (14,224 ft) for the top-contact elevation of the crystalline basement.

\subsubsection{Station HAWA (Plates 6 and 6a)}

The stratigraphy of the suprabasalt sediments and top of the Saddle Mountains Basalt (i.e., Elephant Mountain Member) and Rattlesnake Ridge interbed, as well as the bottom of the Saddle Mountains Basalt and Mabton interbed, are based on the nearest borehole, 699-S18-51, located $200 \mathrm{~m}(656 \mathrm{ft})$ to the westsouthwest. Published interpretations are not available for this borehole, but the available borehole data provide reasonable control for the major stratigraphic interpretations.

The stratigraphy for the interior portion of the Saddle Mountains Basalt and associated interbeds is based on the interpreted thickness of stratigraphic units from five boreholes located 2.8 to $8.5 \mathrm{~km}(1.7$ to $5.3 \mathrm{mi}$ ) away. Differences in the interpreted thicknesses of any of the stratigraphic units range up to $45 \mathrm{~m}$ (147 ft). The model contact elevation for the top of the Saddle Mountains Basalt extracted from Thorne et al.'s (in press) solid Earth model differed by about $4 \mathrm{~m}(12 \mathrm{ft})$; the contact elevation difference for the top of the Wanapum Basalt differed by $17 \mathrm{~m}(56 \mathrm{ft})$.

Two different conceptual models examined by Thorne et al. (in press) yielded a difference in the solid Earth model output of 4,335 m (14,224 ft) for the top-contact elevation of the crystalline basement.

\subsubsection{Station WIA/WIB (Plate 17)}

Temporary stations WIA and WIB were located approximately $775 \mathrm{~m}(2,540 \mathrm{ft})$ apart, with the

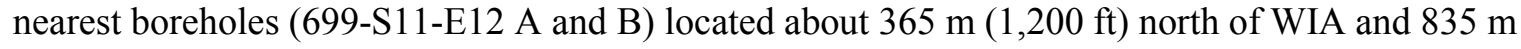
$(2,740 \mathrm{ft})$ west-northwest of WIB. The next closest borehole (699-S16-E-14 [DC-15]) is located about $1,200 \mathrm{~m}(3,900 \mathrm{ft})$ to the south or southeast. A single stratigraphic profile was developed for these stations based on a location midway between them or about $390 \mathrm{~m}(1,270 \mathrm{ft})$ from each of the estimated station locations.

The stratigraphy of the suprabasalt sediments was based on the average stratigraphic contact elevations for boreholes 699-S11-E12 A and B, taken from Thorne et al. (2006). These contact elevations varied by a maximum of $0.5 \mathrm{~m}(1.6 \mathrm{ft})$. The top of the basalt was extrapolated from the average contact elevations for boreholes 699-S11-E12 A and B taken from Thorne et al. (2006), and the contact depth for the top of the Ice Harbor Member for borehole 699-S16-E-14 (DC-15) taken from Landon (1985). The interpreted elevations between these two borehole locations varied by about $15.6 \mathrm{~m}(51 \mathrm{ft})$ and about 5-10 $\mathrm{m}(16-33 \mathrm{ft})$ from the extrapolated estimate for the WIA/WIB location. This suggests that the

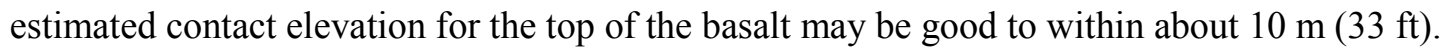

The stratigraphy for the Saddle Mountains Basalt and associated interbeds was based on the interpreted stratigraphic thicknesses from a single borehole 699-S16-E-14 (DC-15), located about $1,130 \mathrm{~m}(3,715 \mathrm{ft})$ to the south-southeast, as taken from Landon (1985). 


\subsubsection{Station WIXX (Plate 18)}

The stratigraphy of the suprabasalt sediments was based on a variety of interpreted stratigraphic contacts for boreholes between 120 and $650 \mathrm{~m}$ (390 and 2,130 ft) away, including 699-S19-E14 from Swanson (1992). Where multiple contact interpretations are available for wells in close proximity to each other (e.g., Thorne et al. 2006 - for 399-1-18A, B and C), the contacts varied by up to $4.8 \mathrm{~m}$ (16 ft). How representative these contact depths are directly beneath the WIXX station is unknown.

The top of the basalt was extrapolated from the contact elevation for borehole 399-1-18C, taken from Thorne et al. (2006), and the contact depth for the top of the Ice Harbor Member from borehole 699-S16E-14 (DC-15) taken from Landon (1985). The interpreted elevations between these two borehole locations varied by about $12.3 \mathrm{~m}(40 \mathrm{ft})$ and about 4-8 $\mathrm{m}(13-26 \mathrm{ft})$ from the extrapolated estimate for the WIXX location. This suggests that the contact elevation for the top of the basalt may be good to within $8 \mathrm{~m}(26 \mathrm{ft})$.

The stratigraphy for the Saddle Mountains Basalt and associated interbeds was based on the interpreted stratigraphic thicknesses from a single borehole 699-S16-E-14 (DC-15), located about $960 \mathrm{~m}$ $(3,150 \mathrm{ft})$ to the north, as taken from Landon (1985).

\subsubsection{Reference Location A1 (Waste Treatment Plant, Plates 7 and 7a)}

The nearest borehole with documented stratigraphic interpretations, C4998, is located approximately $45 \mathrm{~m}$ (148 ft) southwest of the reference location and provides good stratigraphic control for the top of the basalt and suprabasalt sediments (Barnett et al. 2007). A companion borehole with stratigraphic interpretations, C4997, is located $25 \mathrm{~m}$ to the south and $62 \mathrm{~m}$ from the reference location (Barnett et al. 2007). Differences in interpreted stratigraphic contacts suggests that the estimated contact depths and thicknesses for the suprabasalt sediments may be good to within about $3 \mathrm{~m}(10 \mathrm{ft})$.

Two other boreholes (C4993 and C4996) are located within about $307 \mathrm{~m}(1,007 \mathrm{ft})$ to the north and west and have interpreted top-of-basalt elevations that vary up to $25 \mathrm{~m}$ (83 ft) (Barnett et al. 2007). Differences in the interpreted stratigraphic thicknesses for the Saddle Mountains Basalt and associated interbeds varied from 2.4 to $7 \mathrm{~m}$ ( 8 to $23 \mathrm{ft}$ ) in the top of the section (down to the Selah interbed), and from 0.3 to $3.7 \mathrm{~m} \mathrm{(1} \mathrm{to} 12 \mathrm{ft}$ ) from there down (Barnett et al. 2007). The model contact elevation for the top of the Saddle Mountains Basalt extracted from Thorne et al.'s (in press) solid Earth model differed by about $14 \mathrm{~m}(46 \mathrm{ft})$; the contact elevation difference for the top of the Wanapum Basalt differed by $13 \mathrm{~m}$ $(43 \mathrm{ft})$.

Two different conceptual models examined by Thorne et al. (in press) yielded a difference in the solid Earth model output of 5,324 m (17,468 ft) for the top-contact elevation of the crystalline basement.

\subsubsection{Reference Location B and Seismometer Station H2W1998 (Plates 8 and 8a)}

The stratigraphy of the suprabasalt sediments and the contact for the top of the basalt were extrapolated from structure contour maps provided by Last et al. (2009a). The scale of these maps and the 3-m (10-ft) elevation contour interval relative to the estimated location of the reference location suggests that the contact elevation for the top of the basalt and suprabasalt sediments may be good to 
within about $3 \mathrm{~m}(10 \mathrm{ft})$. Comparison with borehole logs from the nearest borehole, 299-W17-2, located $143 \mathrm{~m}(469 \mathrm{ft})$ to the west, suggests that the estimated locations of the contacts are accurate to within about $1.2-2.1 \mathrm{~m}(4-7 \mathrm{ft})$.

The stratigraphy of the Saddle Mountains Basalt and associated interbeds was extrapolated from the average thicknesses interpreted from three boreholes located 1.7 to $2.5 \mathrm{~km}$ (1.1 to $1.6 \mathrm{mi}$ ) away - to the northwest and northeast of the reference location. The difference in the interpreted thicknesses for each of these units ranged from 3 to $6.7 \mathrm{~m} \mathrm{(10} \mathrm{to} 22 \mathrm{ft})$ down through the Esquatzel Member, and from 8.8 to $21 \mathrm{~m}$ ( 29 to $70 \mathrm{ft}$ ) for the lowermost portion of the Saddle Mountains Basalt. The model contact elevation for the top of the Saddle Mountains Basalt extracted from Thorne et al.'s (in press) solid Earth model differed by about $5 \mathrm{~m}(15 \mathrm{ft})$; the contact elevation difference for the top of the Wanapum Basalt differed by $10 \mathrm{~m}(32 \mathrm{ft})$.

Two different conceptual models examined by Thorne et al. (in press) yielded a difference in the solid Earth model output of 5,324 m (17,468 ft) for the top-contact elevation of the crystalline basement.

The original location of the H2W seismometer station (designated H2W1998) is a bit uncertain. Conrads (1997) indicated that it was at a location that is approximately $195 \mathrm{~m}(640 \mathrm{ft})$ north of reference location B. The stratigraphic thicknesses for the Saddle Mountains Basalt are expected to be similar for seismometer station H2W1998. However, the elevation of the top of the basalt surface is estimated to be about $4 \mathrm{~m}(13 \mathrm{ft})$ higher. The elevation of suprabasalt stratigraphic contacts may also vary up to about $5 \mathrm{~m}(16 \mathrm{ft})$ from that estimated for reference location B.

\subsubsection{Reference Location C (Columbia Generating Station, Plates 9 and 9a)}

The stratigraphy of the suprabasalt sediments and uppermost Saddle Mountains Basalt is based on work by Bechtel (2013) and is presumably defined by three boreholes located 42 to $873 \mathrm{~m}$ (138 to $2,865 \mathrm{ft}$ ) away. Comparison of this stratigraphy with interpreted contact information provided by Thorne et al. (2006) for borehole 699-12-1A (B-12) located $42 \mathrm{~m}$ (138 ft) from the reference location, found that the difference in interpreted contact depths for the major suprabasalt strata and the top of the basalt vary by 1.2 to $5.8 \mathrm{~m}$ (4 to $19 \mathrm{ft}$ ). The model contact elevation for the top of the Saddle Mountains Basalt extracted from Thorne et al.'s (in press) solid Earth model differed by about $7 \mathrm{~m}(22 \mathrm{ft})$.

The stratigraphy for the lower portion of the Saddle Mountains Basalt and associated interbeds was based on interpreted stratigraphic contacts and thicknesses from four boreholes located 4.2 to $5.5 \mathrm{~km}$ ( 2.6 to $3.5 \mathrm{mi}$ ) away. The interpreted stratigraphic thicknesses between these boreholes vary by as much as 15.2 to $26.5 \mathrm{~m}$ ( 50 to $87 \mathrm{ft}$ ). Some of this variation in thickness is due to the presence of additional basalt flows (the Esquatzel 2 flow and the Asotin flow) and unnamed interbeds identified in two of the four boreholes. Thus, there is not only uncertainty about the thickness of the stratigraphic units but also about the number of stratigraphic units. The model contact elevation for the top of the Wanapum Basalt differed by over $5 \mathrm{~m}(18 \mathrm{ft})$.

Two different conceptual models examined by Thorne et al. (in press) yielded a difference in the solid Earth model output of 4,904 m (16,090 ft) for the top-contact elevation of the crystalline basement. 


\subsubsection{Reference Location D (105-B, Plates 10 and 10a)}

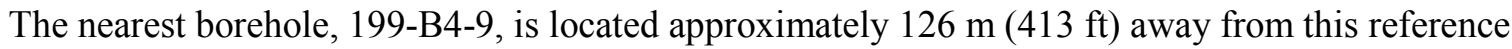
location, and it provides good stratigraphic control only down to the top of the Ringold Formation member of Wooded Island, Unit E (Rwie). The stratigraphy for the upper portion of the Ringold Formation is extrapolated from the average thickness from this and four other boreholes located within about $0.5 \mathrm{~km}(0.3 \mathrm{mi})$ away (Hartman 2011). The range in the interpreted elevation for these units varies by about $3 \mathrm{~m}(10 \mathrm{ft})$. The stratigraphy for the lower portion of the Ringold Formation is based on the interpreted contacts provided by Thorne et al. (2006) for one borehole located nearly $1 \mathrm{~km}(0.62 \mathrm{mi})$ away.

The elevation of the top of the basalt was based on the structure contour map of the basalt surface derived from Thorne et al. (2006). The scale of this map and the 20-m (65.5-ft) elevation contour interval relative to the estimated location and elevation of the station suggests that the estimated contact elevation for the top of the basalt may be accurate to within about $10 \mathrm{~m}(33 \mathrm{ft})$. The stratigraphy of the upper portion of the Saddle Mountains Basalt and associated interbeds was extrapolated from the average thickness from three boreholes located 7 to $8 \mathrm{~km}$ (4 to $5 \mathrm{mi}$ ) away-all northeast of the reference location. Where multiple interpretations are available, the range in interpreted thicknesses for each of these units varied from 0.6 to $4.6 \mathrm{~m}$ ( 2 to $15 \mathrm{ft}$ ). The model contact elevation for the top of the Saddle Mountains Basalt extracted from Thorne's solid Earth model differed by about $3 \mathrm{~m}(10 \mathrm{ft})$.

The stratigraphy for the lower portion of the Saddle Mountains Basalt is based on interpreted thicknesses for individual boreholes located up to $8 \mathrm{~km}(5 \mathrm{mi})$ away and isopach maps provided by Myers and Price (1981). Where multiple interpretations are available, the difference in interpreted thicknesses for these units varied by $7 \mathrm{~m}(23 \mathrm{ft})$. The model contact elevation for top of the Wanapum Basalt differed by about $23 \mathrm{~m}(75 \mathrm{ft})$.

Two different conceptual models examined by Thorne (in press) yielded a difference in the solid Earth model output of 3,696 m (12,125 ft) for the top-contact elevation of the crystalline basement.

\subsubsection{Reference Location E (300 Area, Plates 11 and 11a)}

The stratigraphy of the upper suprabasalt sediments was based on a borehole located about $12 \mathrm{~m}$ $(39 \mathrm{ft})$ northwest of this reference location. Existing stratigraphic contact information for borehole 399-3-3 indicates that the top of the Ringold Formation member of Wooded Island, Unit E (Rwie), is

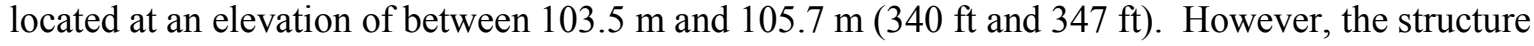
contour map for the top of the Ringold Formation provided by DOE-RL (2011, Figure 3-24) suggests that the top of the Ringold Formation lies at an elevation between $94.5 \mathrm{~m}$ and $96 \mathrm{~m}(310 \mathrm{ft}$ and $315 \mathrm{ft})$. These discrepancies suggest that the estimated contact elevation for the top of the Ringold Formation may be good to within about $10 \mathrm{~m}(33 \mathrm{ft})$. The rest of the suprabasalt stratigraphy is based on the average contact elevations from the two nearest boreholes, 399-3-3 and 399-4-5, where interpreted contacts provided by Thorne et al. (2006) vary by as much as $12 \mathrm{~m}(40 \mathrm{ft})$.

The elevation of the top of the basalt was based on contact elevations interpreted from borehole 399-4-5 located $176 \mathrm{~m}$ (577 ft) to the south-southeast. The stratigraphy for the Saddle Mountains Basalt and associated interbeds was based on the distance-weighted average thickness of each stratigraphic unit as provided by Landon (1985) for two boreholes (699-S30-E14 [DDH-3] and 699-S16-E14 [DC-15]) 
located 1.5 to $3 \mathrm{~km}$ (1 to $1.9 \mathrm{mi}$ ) away, respectively. The difference in the interpreted thicknesses for each of these stratigraphic units varied by up to $13 \mathrm{~m}$ (43 ft). The model contact elevation for the top of the Saddle Mountains Basalt extracted from Thorne et al.'s (in press) solid Earth model differed by about $2 \mathrm{~m}(6 \mathrm{ft})$; the contact elevation for the top of the Wanapum Basalt differed by about $19 \mathrm{~m}(61 \mathrm{ft})$.

Two different conceptual models examined by Thorne et al. (in press) yielded a difference in the solid Earth model output of 4,136 m (13,569 ft) for the top-contact elevation of the crystalline basement.

\subsubsection{Seismometer Station CCRK (Plate 12)}

The elevation of this station is a bit uncertain. Based on field reconnaissance, the elevation of this station was found to be about $27 \mathrm{~m}(90 \mathrm{ft})$ lower that previously reported. ${ }^{1}$ The stratigraphy for this station is also highly uncertain. It is based on interpretation of the Washington State Department of Ecology (WADOE) Well Log ID $138747^{2}$ normalized to the top of the Saddle Mountains Basalt and Wanapum Basalt formations extracted from the Geologic Framework Mapper (Burns et al. 2011). Well 138747 is located about $0.5 \mathrm{~km}$ east and downslope from CCRK. Stratigraphic interpretations are based on the correlation of driller's descriptions from this and other nearby wells with documented interpretations from 699-49-100A (DB-11) from Myers and Price (1981).

\subsubsection{Seismometer Station DDRF (Plate 13)}

The top of the basalt is fairly well constrained by the topography, and the ground-surface elevation is within $0.5 \mathrm{~m}(1.5 \mathrm{ft})$ of the interpreted top of Saddle Mountains Basalt extracted from the Geologic Framework Mapper (Burns et al. 2011). The stratigraphy of the upper Saddle Mountains Basalt is based on interpretation of the WADOE Well Log ID 167864 (located within about $0.5 \mathrm{~km}$ [1,600 ft]) and its correlation with published stratigraphic contacts for boreholes 699-2-E14 [DB-1], 699-15-E3 [DB-2] in Myers and Price (1981), and 699-S16-E14 [DC-15] in Landon (1985), all located about $20 \mathrm{~km}$ to the west and southwest.

There is a good deal of uncertainty about the thickness of Saddle Mountains Basalt. For example, the correlation described above, suggests that the Ice Harbor Member could be about $22 \mathrm{~m}$ (72 ft) thick, but Lindsey et al. (2009, Plate 16) suggest that the Ice Harbor Member and Levy interbed may be missing or very thin. There are a number of other discrepancies between long-distance correlations done for this study, interpretations in the Geologic Framework Mapper (Burns et al. 2011), and those of Lindsey et al. (2009), suggesting that there may be as much as $60 \mathrm{~m}$ (200 ft) of uncertainty in the total thickness of the Saddle Mountains Basalt.

\subsubsection{Seismometer Station FHE (Plate 14)}

There is a lot of uncertainty regarding the stratigraphy for this station. While the top of the basalt is fairly well constrained by the topography, the stratigraphy and thickness of the Saddle Mountains Basalt are highly uncertain. The stratigraphy developed for this study is based on interpretation of WADOE Well Log ID 454842 correlated with the extent of basalt flows portrayed by DOE (1988, Figures 1.2-2p

\footnotetext{
${ }^{1}$ Email from Alan Rohay to distribution, dated September 3, 2013.

${ }^{2}$ Washington State Well Log Viewer (http://apps.ecy.wa.gov/welllog/index.asp).
} 
through 1.2-2cc), and Lindsey (2009, Plates 22 and 24), normalized to the modeled thickness for the Saddle Mountains (Burns et al. 2011). Comparison of the top-contact elevation for the Wanapum Basalt of Lindsey et al. (2009) with that modeled by Burns et al. (2011) suggests a difference of about $30 \mathrm{~m}$ $(90 \mathrm{ft})$.

\subsubsection{Seismometer Station PHIN (Plate 15)}

Interpretation of the stratigraphy beneath this station is also highly uncertain. The tops of the Saddle Mountains Basalt and Wanapum Basalt are based on data extracted from the Geologic Framework Mapper (Burns et al. 2011), and were used to constrain the rest of the stratigraphy. The stratigraphy of the suprabasalt sediments and internal to the Saddle Mountains Basalt was based on interpretation of WADOE Well Logs ID 302785 and ID 139808. The presence and thickness of individual members of the Saddle Mountains Basalt Formation are highly uncertain.

\subsubsection{Seismometer Station GBB (Plate 16)}

Station GBB is located on basalt. The top of the basalt (i.e., the Saddle Mountains Basalt) is constrained by the topography and by the top of basalt interpreted by Fecht (1978) and Myers and Price (1981, Sheet 4), showing the Elephant Mountain Member at the ground surface. Interpretation of the stratigraphy internal to the upper portions of the Saddle Mountains Basalt is based upon stratigraphic thicknesses in deep boreholes 699-61-57 [DB-9] and 699-63-95 [DB-12]), located $6 \mathrm{~km}$ away, and 699-84-59 (BH-16) located 8.9 km away, taken from Myers and Price (1984, Table A.2). This information was supplemented by interpretation of borehole log summaries for 699-81-62 (BH-17) and 699-86-64 (BH-18) based on Fecht et al. (1984). The stratigraphy of the lower portion of the Saddle Mountains Basalt is based on the interpreted stratigraphic thicknesses for 699-61-57 (DB-9) and/or 699-63-95 (DB-12) taken from Myers and Price (1981, Table A-2).

The presence and thickness of individual members of the Saddle Mountains Basalt and the top of the Wanapum Basalt are highly uncertain. Where multiple interpretations are available, the range in interpreted thickness for some of these units (e.g., Pomona or Umatilla) varied by up to $29 \mathrm{ft}(8.8 \mathrm{~m})$. In the case of the Esquatzel Member and Asotin Member, interpretations from well 699-61-57 (DB-9) indicate that both of these members are present, occupying a combined thickness of $180 \mathrm{ft}(55 \mathrm{~m})$, while interpretations for well 699-63-95 (DB-12) indicate that they are not present. Thus, the estimated top of the Wanapum Basalt could be off by more than $180 \mathrm{ft}(55 \mathrm{~m})$.

\subsubsection{Seismometer Station WOLL (Plate 19)}

Interpretation of the stratigraphy beneath this station is fairly uncertain. The tops of the Wanapum Basalt and Grande Ronde Basalt are based on data extracted from Thorne et al.'s (in press) solid Earth model of data from (Burns et al. 2011). These contacts were then used to constrain the rest of the stratigraphy. The stratigraphy internal to the Wanapum Basalt was based on interpretation of WADOE Well Logs ID 174109/659838 and 174078, correlated with the extent of basalt flows portrayed by DOE (1988) and their elevation and thickness reported by Lindsey et al. (2009). The presence and thickness of individual members of the Saddle Mountains Basalt are fairly uncertain. 


\subsubsection{Seismometer Station TUCA (Plate 20)}

Interpretation of the stratigraphy beneath this station is fairly uncertain. The top of the Grande Ronde Basalt is based on data extracted from Thorne et al.'s (in press) solid Earth model of data from (Burns et al. 2011). Information about the depth to the basalt and thickness of the suprabasalt sediments is based on interpretation of WADOE Well Logs ID 164097 and 654073.

\subsection{Conclusions}

Stratigraphic profiles were constructed for eight selected Hanford Site seismometer stations, five Hanford Site facility reference locations, and seven regional three-component broadband seismometer stations. These profiles provide interpretations of the subsurface layers to support estimation of ground motions from past earthquakes, and the prediction of ground motions from future earthquakes. In most cases these profiles terminated at the top of the Wanapum Basalt, but at selected sites the stratigraphic profiles were extended down to the top of the crystalline basement. The composite one-dimensional stratigraphic profiles were based primarily on previous interpretations from nearby boreholes, and in many cases the nearest deep borehole is located kilometers away.

A number of potential sources of uncertainty exist concerning the site locations, elevations, and extrapolation of interpreted stratigraphic contacts. Stratigraphic contacts used in this report are based on interpretation of borehole data from a number of different individuals for different environmental programs, often using different stratigraphic nomenclature. Sources of uncertainty include 1) the quality of subsurface data, which is influenced by the drilling technique, the logging of the borehole, and sample collection; 2) subtle differences between some stratigraphic units that makes identification of the stratigraphic contacts difficult; and 3) uncertainty in the geometric shape of the stratigraphic units. Where suitable, existing structure contour and isopach maps, as well as cross sections, and solid Earth model information, and on rare occasions some field checking were used to help verify or adjust station location information and the stratigraphic contacts to improve extrapolation of borehole data from distant boreholes. 


\subsection{References}

Barnett DB, KR Fecht, SP Reidel, BN Bjornstad, DC Lanigan, and CF Rust. 2007. Geology of the Waste Treatment Plant Seismic Boreholes. Richland, Washington. PNNL-16407 Rev. 1, Pacific Northwest National Laboratory, Richland, Washington

Bechtel (Bechtel Power Corporation). 2013. Assessment of Dynamic Geotechnical Data for the Columbia Generating Station Site. Prepared by Geotechnical and Hydraulic Engineering Services, Fredrick, Maryland.

Bjornstad BN. 1984. Suprabasalt Stratigraphy Within and Adjacent to the Reference Repository Location. SD-BWI-DP-039, Rockwell Hanford Operations, Richland, Washington.

Bodin P, J Vidale, and A Wright. 2012. Hanford Seismic Report for Fiscal Year 2012 (October 2011 September 2012). Prepared for the Mission Support Alliance, LLC under award 44955. Pacific Northwest Seismic Network, University of Washington, Seattle, Washington.

Brown DJ. 1959. Subsurface Geology of the Hanford Separation Areas. HW-61780, General Electric Company, Richland, Washington.

Brown DJ. 1960. An Eolian Deposit Beneath 200-West Area. HW-67549, General Electric Company, Richland, Washington.

Budnitz RJ, G Apostolakis, DM Boore, LS Cluff, KJ Coppersmith, CA Cornell, PA Morris. 1997. Recommendations for Probabilistic Seismic Hazard Analysis: Guidance on Uncertainty and Use of Experts. NUREG/CR-6372, U.S. Nuclear Regulatory Commission, Washington, D.C.

Burns ER, DS Morgan, RS Peavler, and SC Kahle. 2011. Three-Dimensional Model of the Geologic Framework for the Columbia Plateau Regional Aquifer System, Idaho, Oregon, and Washington. Scientific Investigations Report 2010-5246, U.S. Geological Survey, Reston, Virginia.

Campbell NP. 1989. "Structural and stratigraphic interpretation of rocks under the Yakima fold belt, Columbia Basin, based on recent surface mapping and well data." In Volcanism and Tectonism in the Columbia River Flood-Basalt Province. SP Reidel and PR Hooper (eds.). Special Paper 230, Geological Society of America, Boulder, Colorado.

Conrads TJ. 1997. Hanford Strong Motion Accelerometer Network: A Summary of the First Months of Operation. HNF-SD-GN-ER-508, Rev. 0, Numatec Hanford Company, Richland, Washington.

DOE (U.S. Department of Energy). 1988. Consultation Draft, Site Characterization Plan, Reference Repository Location, Hanford Site, Washington. DOE/RW-0164, Volume 1 of 9, Washington, D.C.

DOE-RL (U.S. Department of Energy, Richland Operations Office). 2002. Standardized Stratigraphic Nomenclature for Post-Ringold Formation Sediments ithin the Central Pasco Basin. DOE/RL-2002-39, Rev. 0, Richland, Washington.

DOE-RL (U.S. Department of Energy, Richland Operations Office). 2011. Remedial Investigation/ Feasibility Study for the 300-FF-1, 300-FF-2, and 300-FF-5 Operable Units. DOE/RL-2010-99, Draft A, Richland, Washington. 
Fecht KR. 1978. Geology of the Gable Mountain - Gable Butte Area. RHO-BWI-LD-5, Rockwell Hanford Operations, Richland, Washington.

Fecht KR, JT Lillie, and MA Chamness. 1984. Catalog of Borehole Descriptive Logs from the 600 Area, Hanford Site. Site Department, Basalt Waste Isolation Project, Rockwell Hanford Operations, Richland, Washington.

Glover DW. 1985. Crustal structure of the Columbia Basin, Washington (M.S. thesis). University of Washington, Seattle, Washington.

Hartman MJ. 2011. 100 Area Stratigraphic Database Development. ECF-100NPL-11-0070, Revision 2, CH2MHill Plateau Remediation Company, Richland, Washington.

HPSHA (Hanford Probabilistic Seismic Hazard Analysis). 2012. Workshop Report, Hanford Probabilistic Seismic Hazard Analysis. Workshop 1: Hazard Significant Issues and Available Data, July 23-27, 2012. Embassy Suites Hotel, Walnut Creek, California. PNNL-21985, Pacific Northwest National Laboratory, Richland, Washington.

HPSHA (Hanford Probabilistic Seismic Hazard Analysis). 2013. Workshop Report, Hanford Probabilistic Seismic Hazard Analysis. Workshop 2: Review of Database and Discussion of Alternative Models, December 3-8, 2012. Embassy Suites Hotel, Walnut Creek, California. PNNL-22254, Pacific Northwest National Laboratory, Richland, Washington.

Landon RD. 1985. Deep Borehole Stratigraphic Correlation Charts. SD-BWI-DP-035, Rev. 3, Rockwell Hanford Operations, Richland, Washington.

Lanigan DC, GV Last, BN Bjornstad, PD Thorne, and WD Webber. 2010. Hanford Site Guidelines for Preparation and Presentation of Geologic Information. PNNL-18819 Rev. 1, Pacific Northwest National Laboratory, Richland, Washington.

Last GV, PD Thorne, JA Horner, KR Parker, BN Bjornstad, DC Lanigan, and BA Williams. 2009a. Hydrogeology of the Hanford Site Central Plateau - A Status Report for the 200 West Area.

PNNL-17913, Rev. 1, Pacific Northwest National Laboratory, Richland, Washington.

Last GV, PD Thorne, BN Bjornstad, KR Parker, JA Horner, DC Lanigan, and BA Williams. 2009b. Hydrogeology of the Hanford Site Central Plateau - A Status Report for the 200 East Area.

PNNL-18835, Draft Final Report - Limited Distribution, Pacific Northwest National Laboratory Richland, Washington.

Lindsey KA, JL Slate, GK Jaeger, KJ Swett, and RB Mercer. 1994. Geologic Setting of the Low-level Burial Grounds. WHC-SD-EN-TI-290, Westinghouse Hanford Company, Richland, Washington.

Lindsey KA. 1995. Miocene- to Pliocene-Aged Suprabasalt Sediments of the Hanford Site, SouthCentral Washington. BHI-00184, Bechtel Hanford, Inc., Richland, Washington.

Lindsey KA, SE Kos, and KD Reynolds. 2000. Vadose Zone Geology of Boreholes 299-W22-50 and 299-W23-19 S-SX Waste Management Area Hanford Site, South-Central Washington. RPP-6149, Rev. 0, CH2M HILL Hanford Group, Inc., Richland, Washington. 
Lindsey K, T Tolan, M Nelson, and S Loper. 2009. Geologic Framework of Selected Sedimentary and Columbia River Basalt Group Units in the Columbia Basin Ground Water Management Area of Adams, Franklin, Grant, and Lincoln Counties, Washington, Edition 3. Prepared by Columbia Basin Ground Water Management Area of Adams, Franklin, Grant, and Lincoln Counties, Othello, Washington.

Myers CW and SM Price. 1979. Geologic Studies of the Columbia Plateau, A Status Report. RHO-BWI-ST-4, Rockwell Hanford Operations, Richland, Washington.

Myers CW and SM Price (eds.). 1981. Subsurface Geology of the Cold Creek Syncline. RHO-BWIST-14, Rockwell Hanford Operations, Richland, Washington.

Reidel SP and MA Chamness. 2007. Geology Data Package for the Single-Shell Tank Waste Management Areas at the Hanford Site. PNNL-15955, Rev. 1, Pacific Northwest National Laboratory, Richland, Washington.

Reidel SP, TL Tolan, PR Hooper, MH Beeson, KR Fecht, RD Bentley, JL Anderson. 1989a. "The Grande Ronde Basalt, Columbia River Basalt Group, Stratigraphic descriptions and correlations in Washington, Oregon, and Idaho." In: Volcanism and Tectonism in the Columbia River Flood-Basalt Province. SP Reidel and PR Hooper (eds.). Special Paper 230, Geological Society of America, Boulder, Colorado.

Reidel SP, KR Fecht, MC Hagood, and TL Tolan. 1989b. "The geologic evolution of the central Columbia Plateau." In: Volcanism and Tectonism in the Columbia River Flood-Basalt Province. SP Reidel and PR Hooper (eds.). Special Paper 230, Geological Society of America, Boulder, Colorado.

Rohay AC, MD Sweeney, RE Clayton, and JL Devary. 2011. First Quarter Hanford Seismic Report for Fiscal Year 2011. PNNL-20302, Pacific Northwest National Laboratory, Richland, Washington.

Swanson DA, TL Wright, PR Hooper, and RD Bentley. 1979. Revisions in Stratigraphic Nomenclature of the Columbia River Basalt Group. Bulletin 1457-G, U.S. Geological Survey, Washington, D.C.

Swanson LC. 1992. Phase I Hydrogeologic Summary of the 300-FF-5 Operable Unit, 300 Area. WHC-SD-EN-TI-052, Westinghouse Hanford Company, Richland, Washington.

Thorne PD, MP Bergeron, MD Williams, and VL Freedman. 2006. Groundwater Data Package for Hanford Assessments. PNNL-14753, Rev. 1, Pacific Northwest National Laboratory, Richland, Washington.

Thorne PD, AC Rohay, and SP Reidel. (In Press). Development of a Basin Geologic and Seismic Property Model Used to Support Basin-Effects Modeling for the Hanford Probabilistic Seismic Hazards Analysis. PNNL-XXXXX, Pacific Northwest National Laboratory, Richland, Washington. 
Appendix A

Stratigraphic Profiles 


\section{Appendix A}

\section{Stratigraphic Profiles}

Detailed stratigraphic profiles through the Saddle Mountains Basalt and suprabasalt sediments are provided in in Plates 1 through 20. Deep stratigraphic profiles to the top of the crystalline basement are provided in Plates 1a through 11a. 
Plate 1 - General Stratigraphy Beneath Se ismometer Station H1K

(Based on wells 199-B3-2, 199-K-187, 199-K-195, 699-84-59 [BH-16], 699-81-62 [BH-17], 699-86-64 [BH18], 699-57-83B [DC-23], 699-61-57 [DB-9], and 699-63-95 [DB-12])

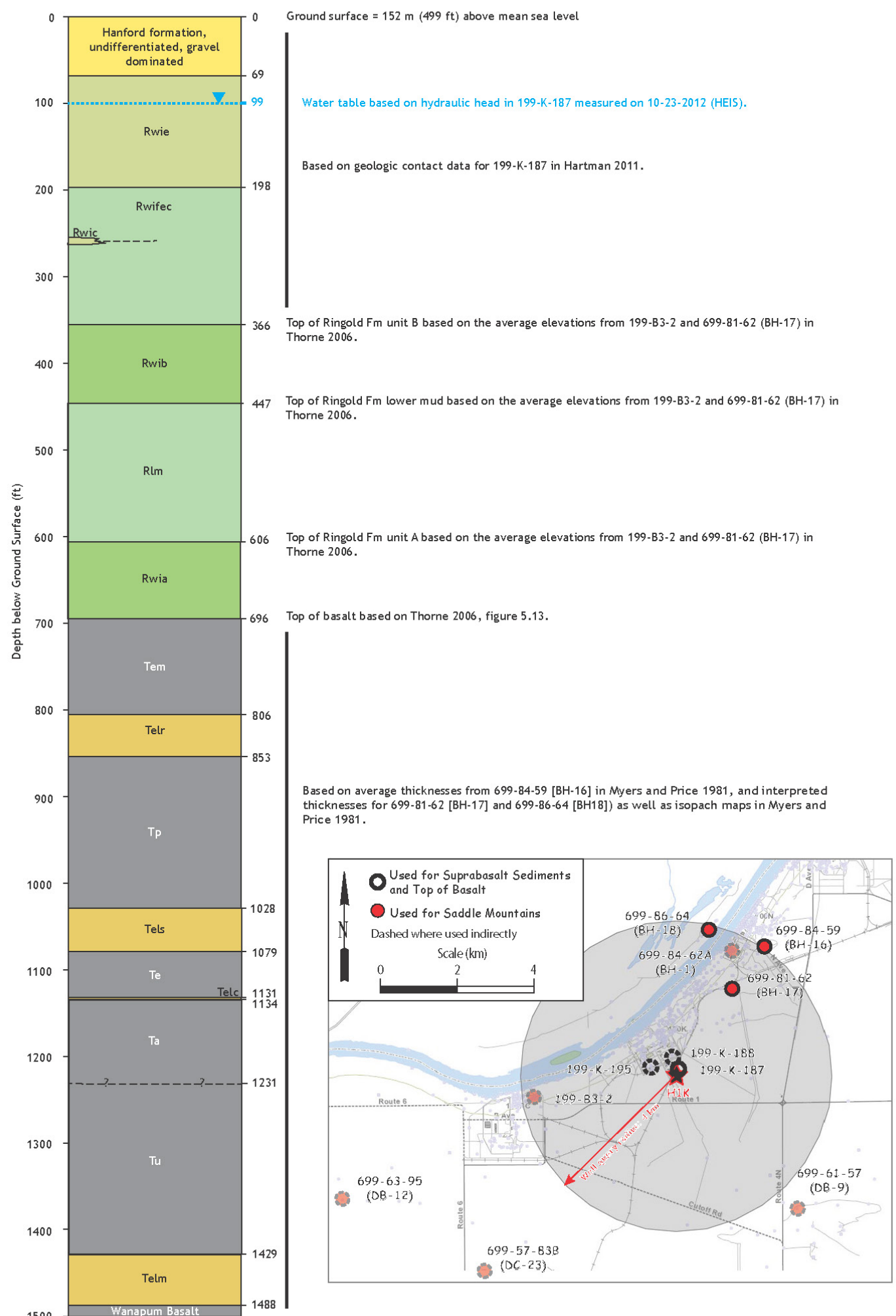


Plate 1a - General Deep Stratigraphy Beneath Seismometer Station H1K

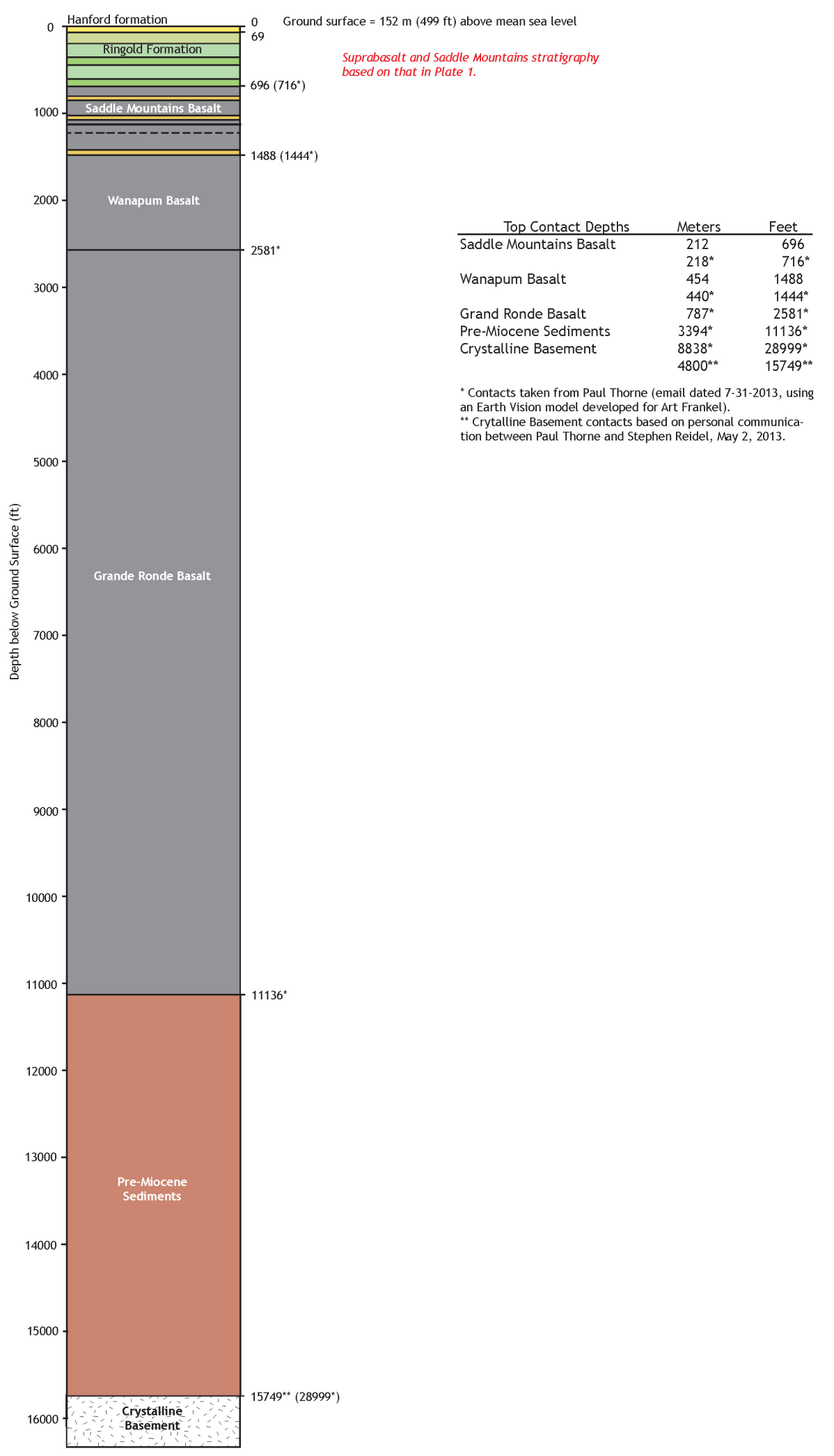




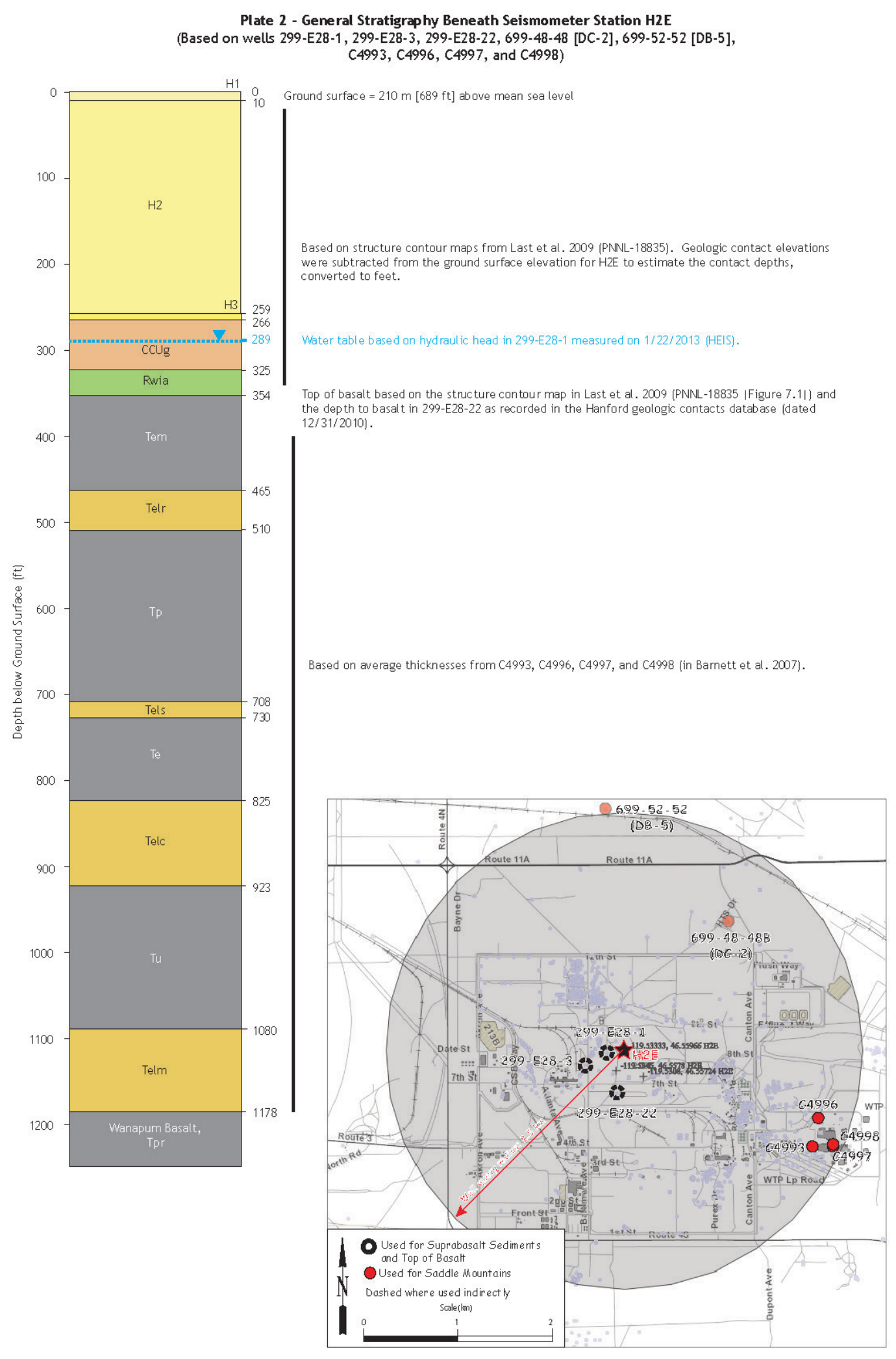


Plate 2a - General Deep Stratigraphy Beneath Seismometer Station H2E

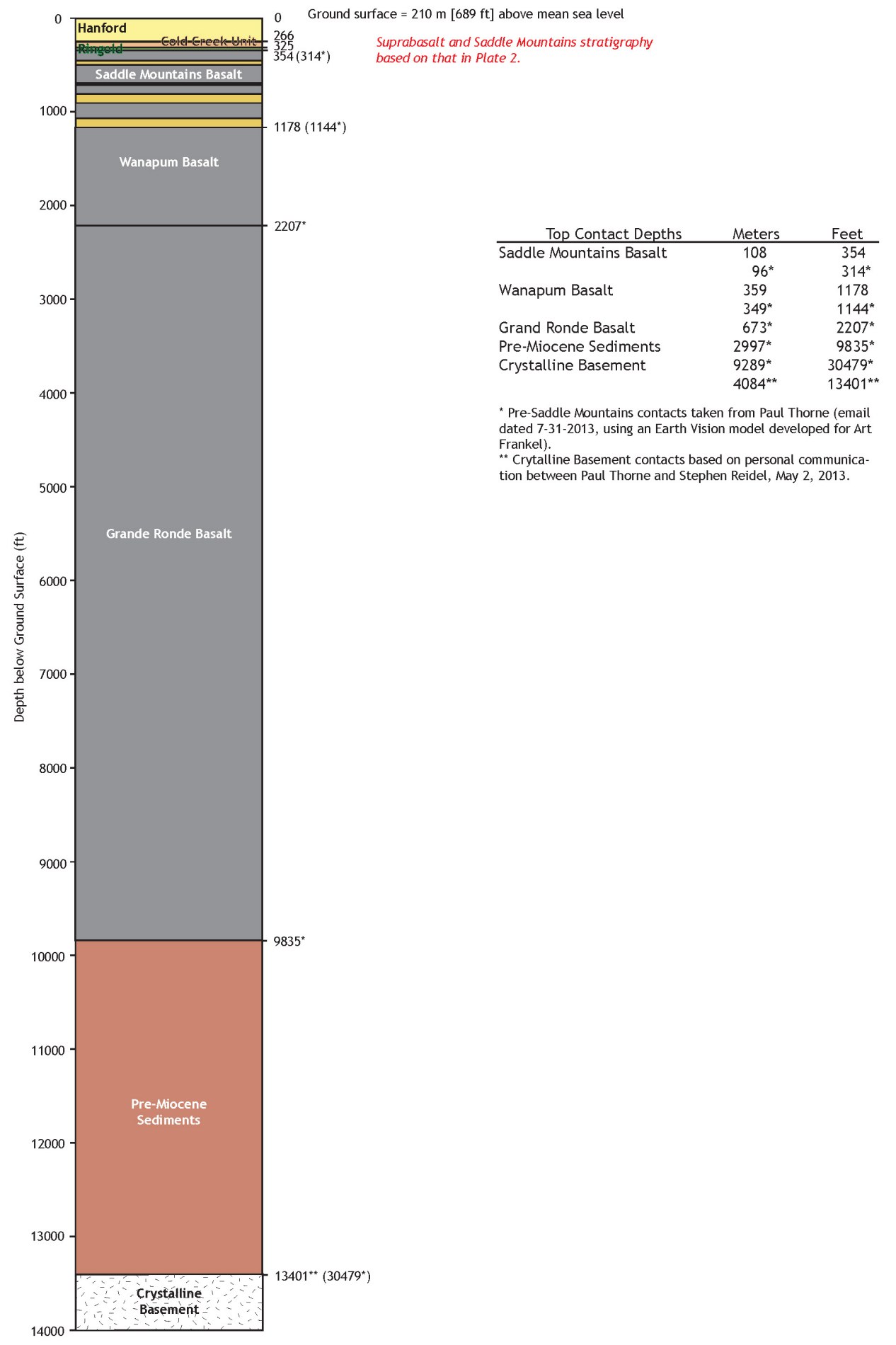


Plate 3 - General Stratigraphy Beneath Seismometer Station H2W

(Based on wells 299-W15-14, 299-W15-20, 299-W15-23,

699-39-84 [RRL-2], 699-40-80 [RRL-9], 699-43-81 [RRL-17], and 699-47-80B [DC-20])

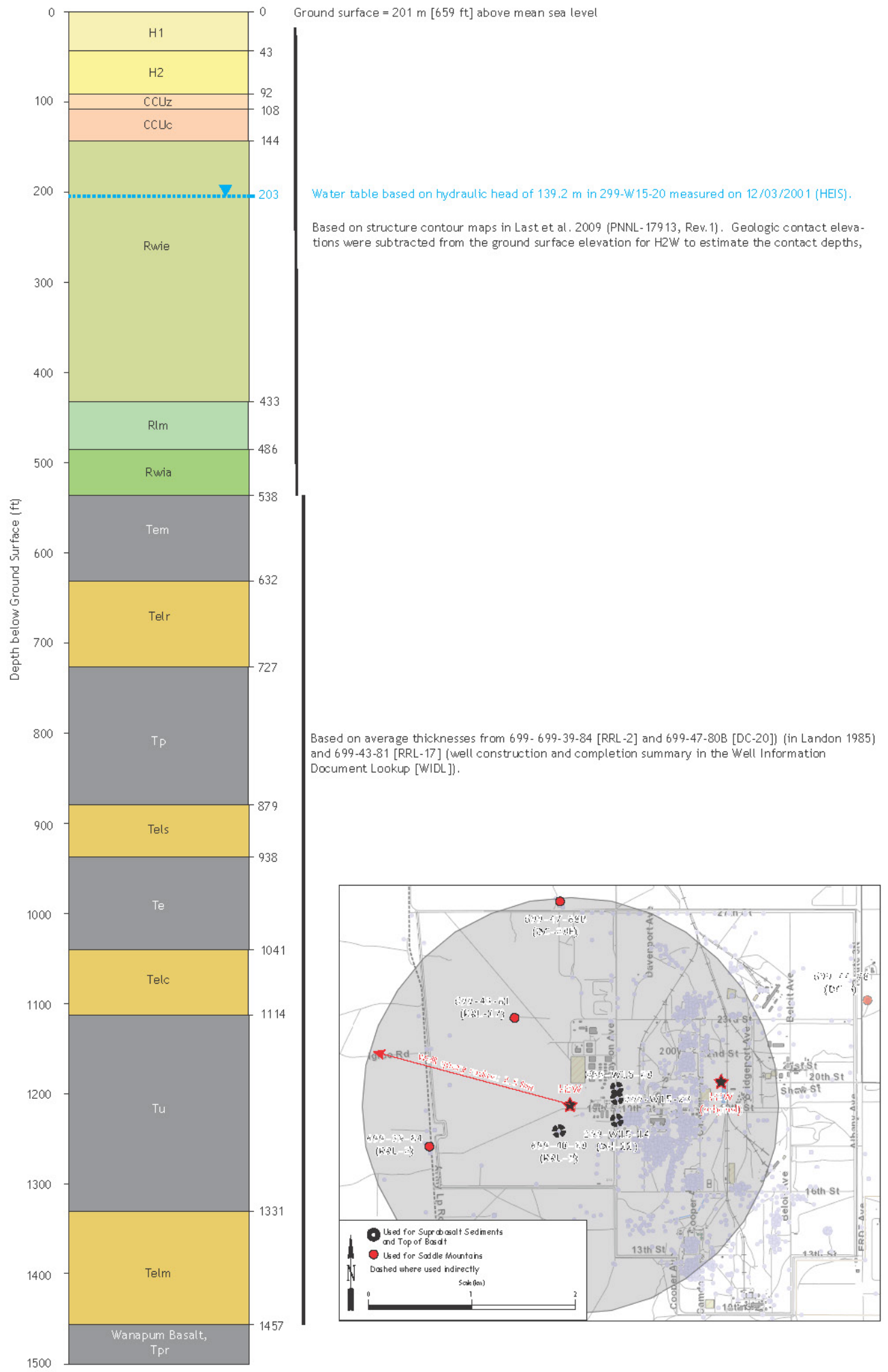


Plate 3a-General Deep Stratigraphy Beneath Seismometer Station H2W

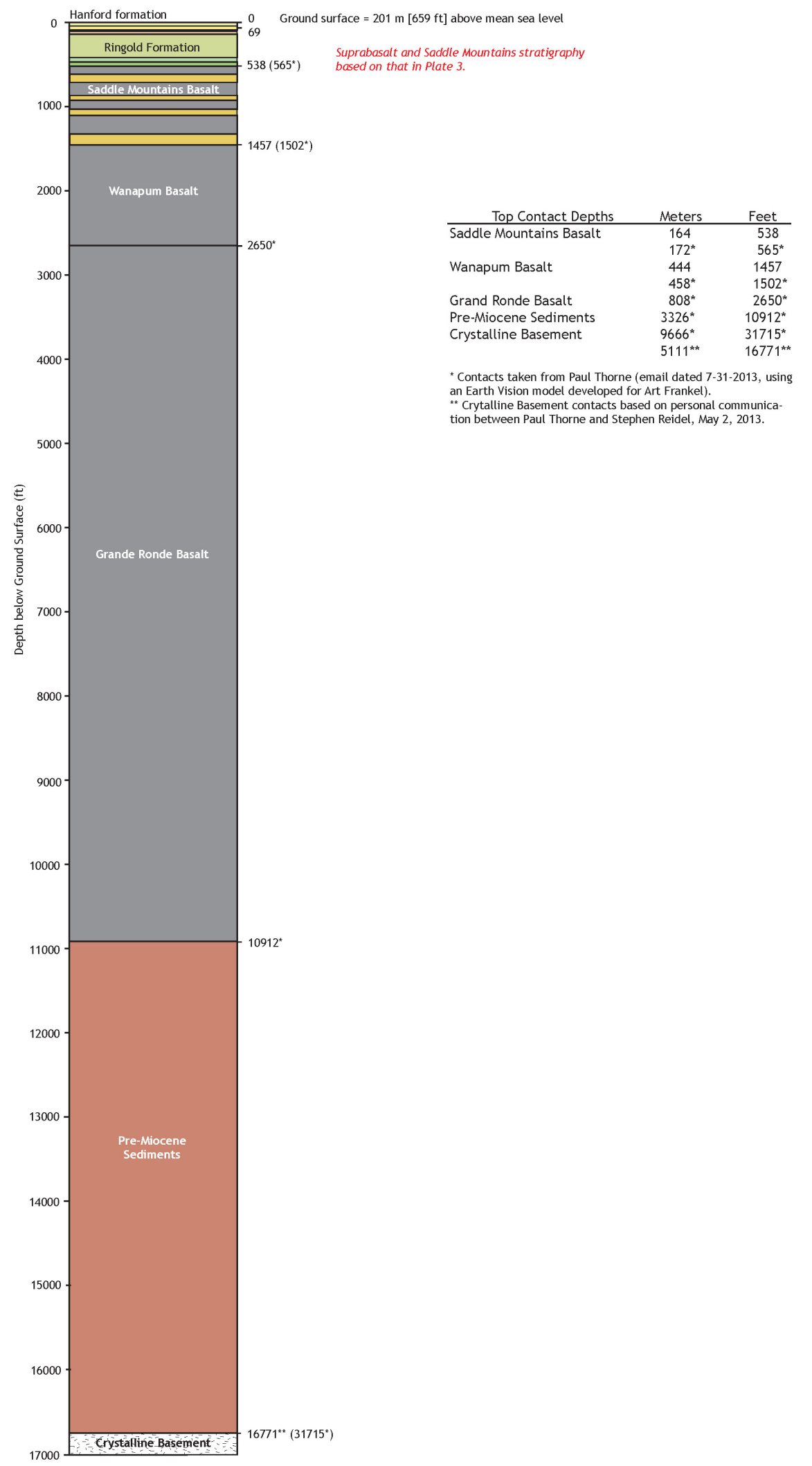


Plate 4 - General Stratigraphy Beneath Seismometer Station H3A

(Based on wells 399-4-5, 399-5-2, 699-S16-E14 [DC-15], 699-S27-E14, 699-S29-E16, 699-S30-E14 [DDH-3])

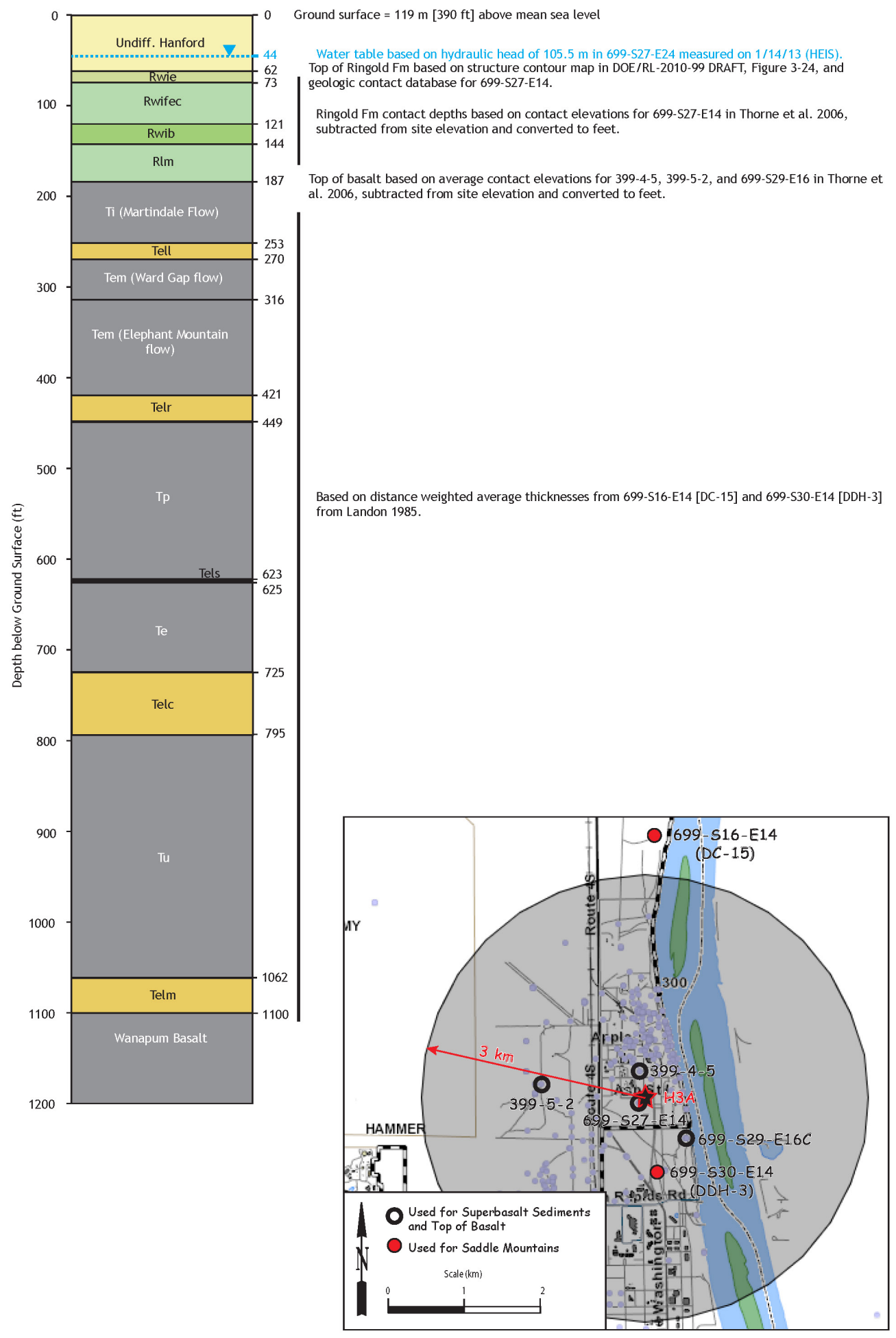




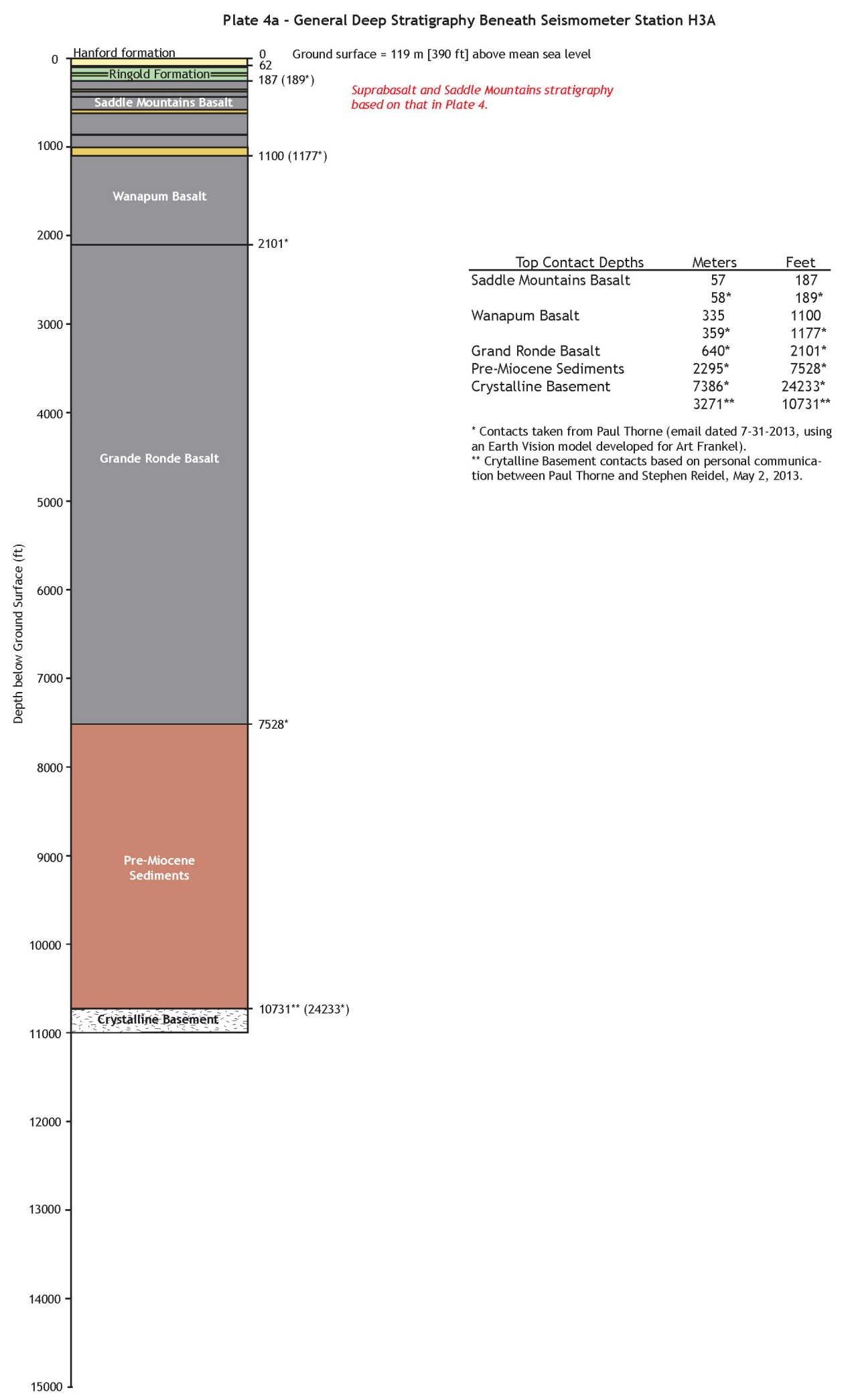


Plate 5 - General Stratigraphy Beneath Seismometer Station H4A

(Based on wells 499-S1-7B and 499-S1-8H [FFTF \#3])

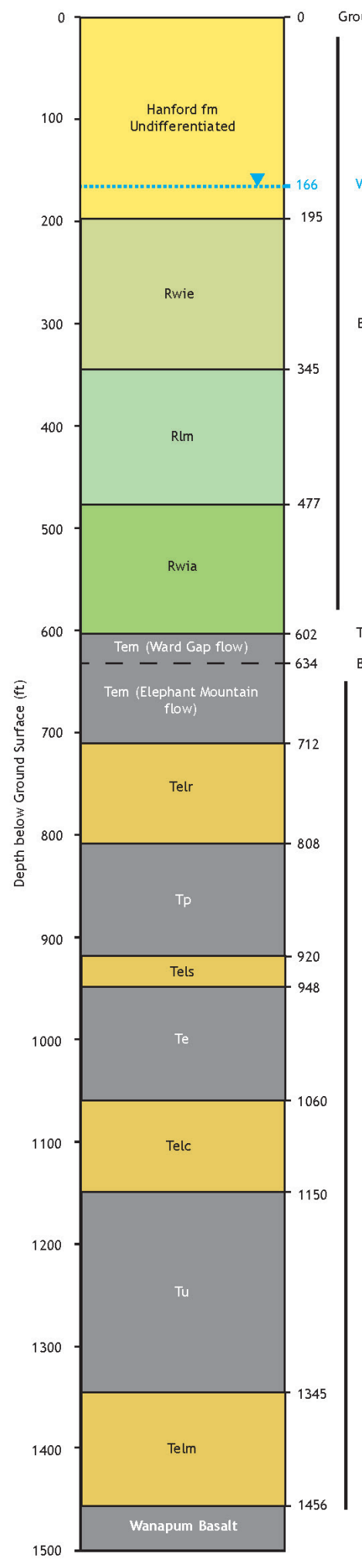

Ground surface $=171 \mathrm{~m}[561 \mathrm{ft}]$ above mean sea level

Water table based on hydraulic head of $120.5 \mathrm{~m}$ in 499-S1-7B measured on 1/25/91 (HEIS).

Based on geo logic contact data for 499-S1-7B in Thorne et al. 2006.

Top of basalt based on geologic contact data for 499-S1-7B in Thorne et al. 2006.

Based on average thickness for 699-S16-E14 (DC-15) and 699-15-15G (DC-8) in Landon 1985.

(

Based on thicknesses for 499-S1-8H in Myers and Price 1981 |RHO-ST-14, Table A.2|.

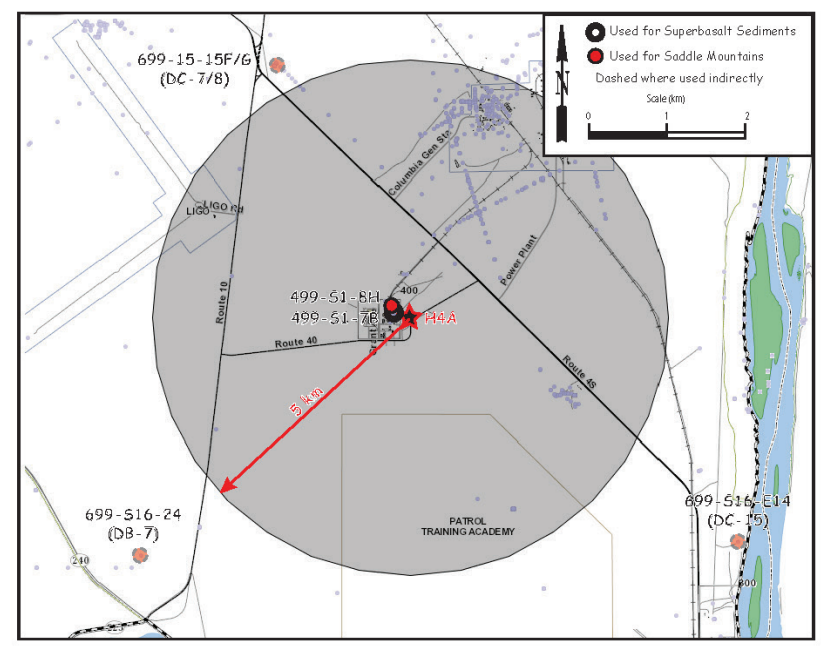




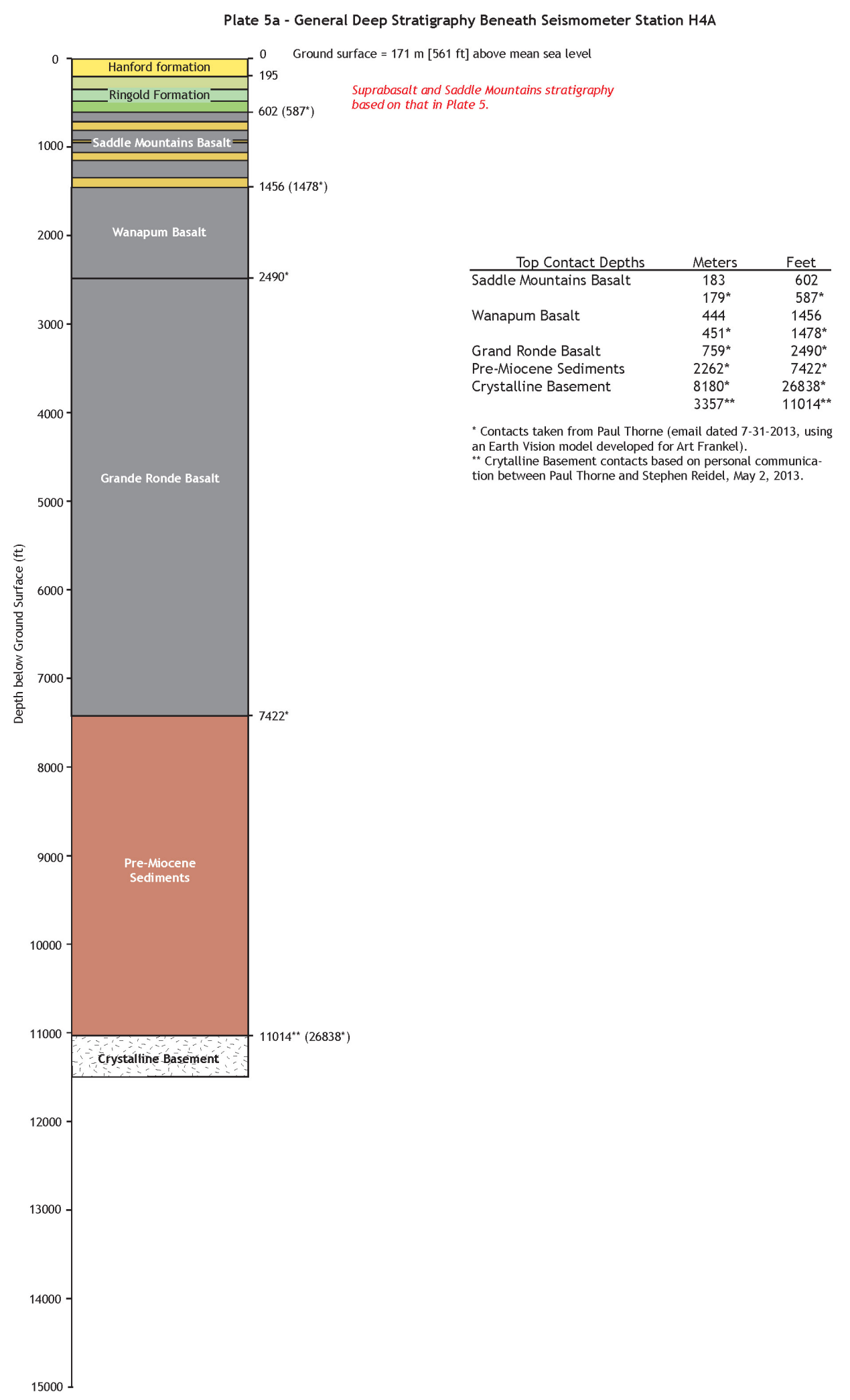


Plate 6 - General Stratigraphy Beneath Seismometer Station HAWA

(Based on wells 699-518-51, 699-59-63B, 699-53-67, 699-516-24, 699-59-56, and 699-10-54B)

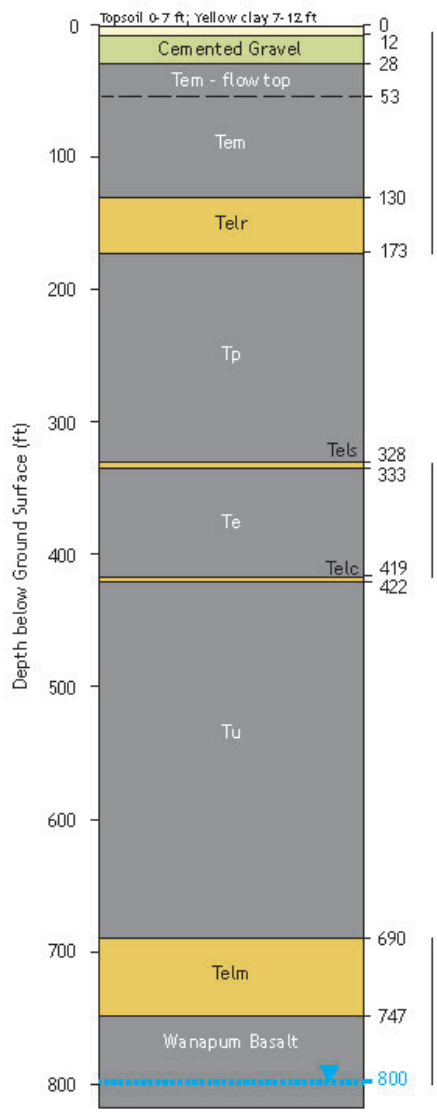

Ground surface ( $369 \mathrm{~m}[1211 \mathrm{ft}$ ] above mean sea level)

Cemented gravel interpreted to be equivalent to Cold Creek unit angular basaltic colluvium

Based on interpretation of well construction and completion summ ary for 699-518-51, modified based on shear wave velodty data from em ail, YC Lin to AC Rohay, dated 6/14/2013.

Based on the average thicknesses for DB-7 in Meyers and Price 1981 and those interpreted from the well construction and completion sum maries for Goodwin \#1 and WWiw-3 (with

geophysical logs!.

Based on the average thicknesses for DE-7 (Mieyers and Price 1981), DC-12 (Landon 1985), and interpretation of the well construction and completion sum mary and geophysical logs for witw $\mathrm{w}-3$.

Based on the thicknesses from WW-6 (Meyers and Price 1981)

Based on interpretation of well corstruction and completion sum mary for 699-518-51, extrapolated to HÄNÁA location.

Depth to water in May 1958, based on Well Corstruction and Completion Sum mary As-Built (WIDL). Other notes suggest "static artesian W. T." is at a depth of 251"

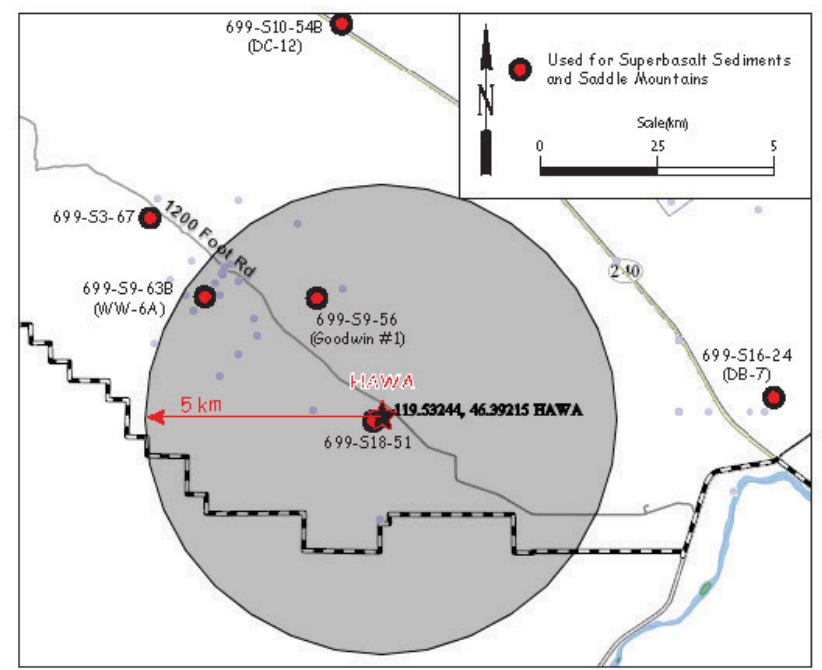

A.12 
Plate 6a - General Deep Stratigraphy Beneath Seismometer Station HAWA

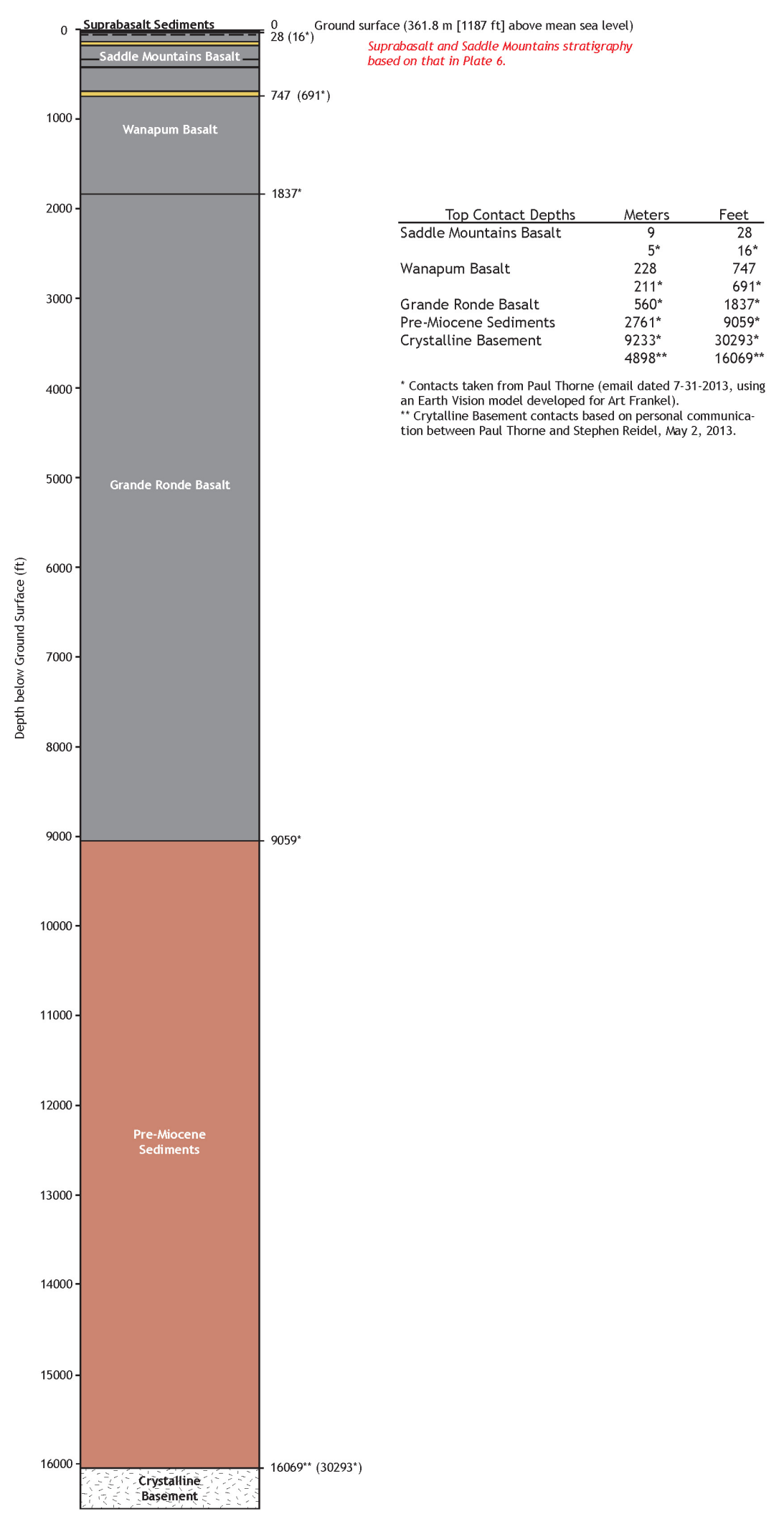

A.13 
Plate 7 - General Stratigraphy Beneath Reference Location A1 (Waste Treatment Plant) (Based on wells C4993, C4996, C4997, and C4998)

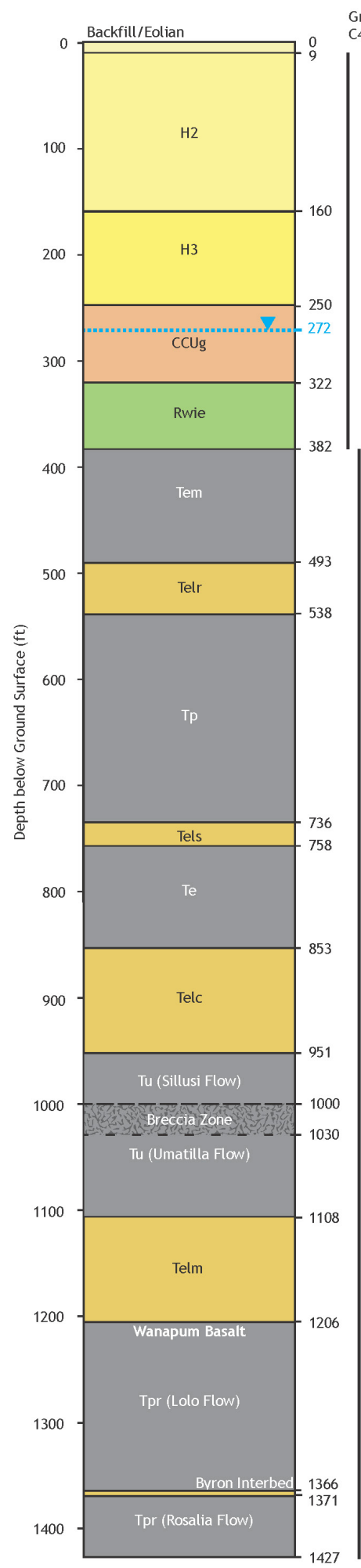

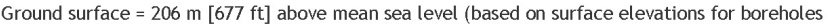
C4997 and C4998 from Barnett et al. 2007 |PNNL-16407, Table 3.2I)

Based on stratigraphic contacts for C4998 in Barnett et al. 2007 |Table 3.2).

Water table based on hydraulic head of $123.1 \mathrm{~m}$ in 299-E25-45 measured on 4/29/98 (HEIS).

Based on average thicknesses from C4993, C4996, C4997, and C4998 in Barnett et al. 2007 | Table

4.11. Breakout of the Sillusi and Umatilla flows based on average thickness interpreted Barnett et

al. 2007 |Table 4.2 and 4.3| and Rohay and Brouns 2007 |Figures 3.2-3.4|

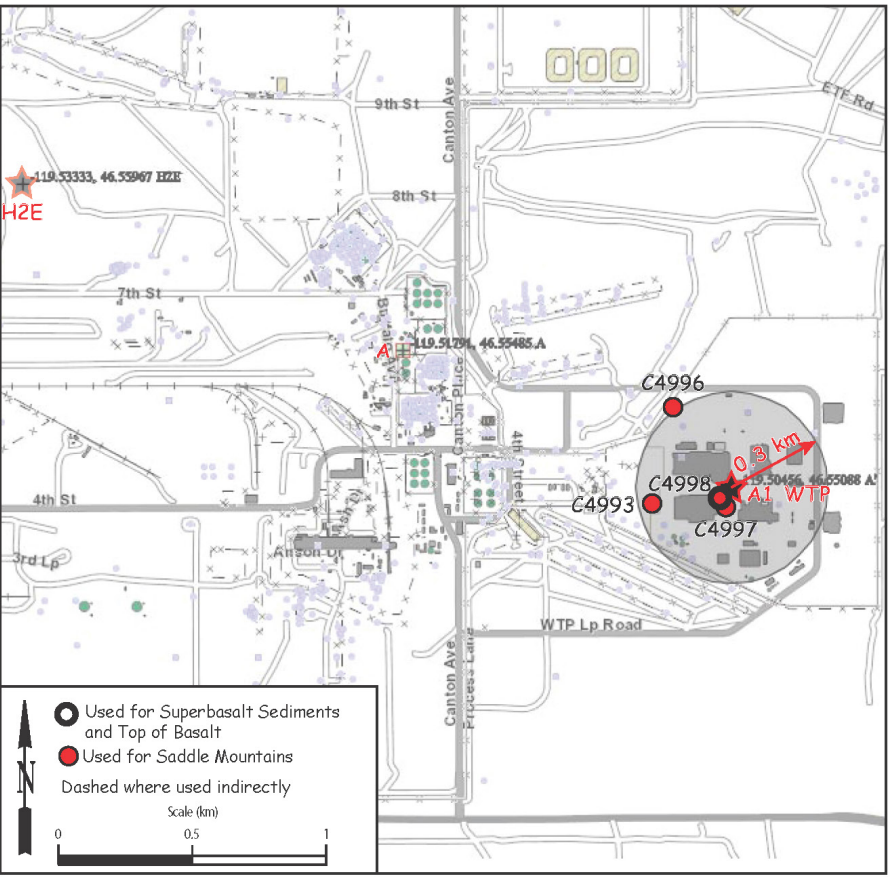


Plate 7 - General Stratigraphy Beneath Reference Location A1 (Waste Treatment Plant) (Based on wells C4993, C4996, C4997, and C4998)

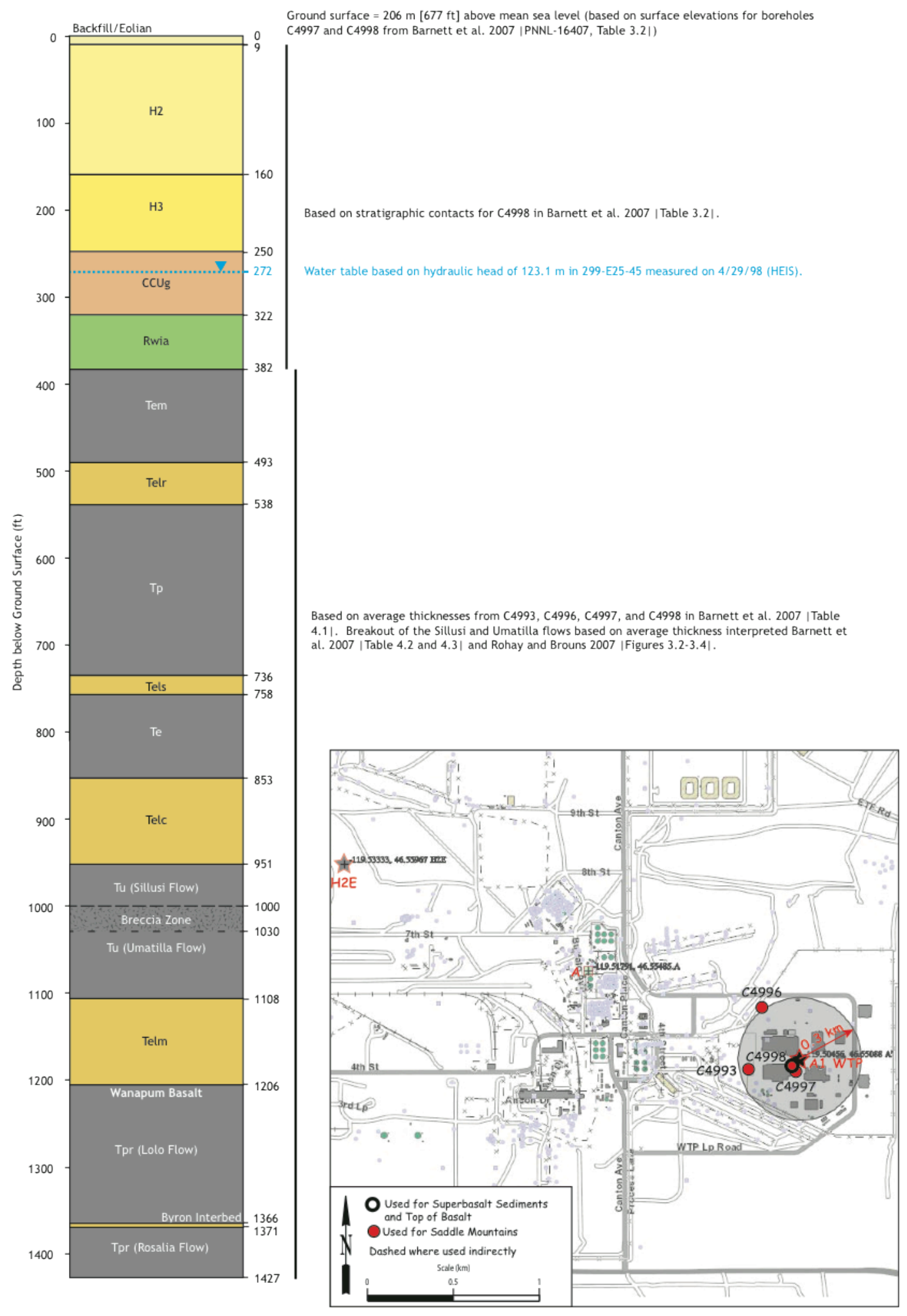


Plate 8 - General Stratigraphy Beneath Reference Location B (200 W) and Seismometer Station H2W1998 (Based on wells 299-W14-9, 299-W14-14, 299-W14-75, 299-W/17-2;

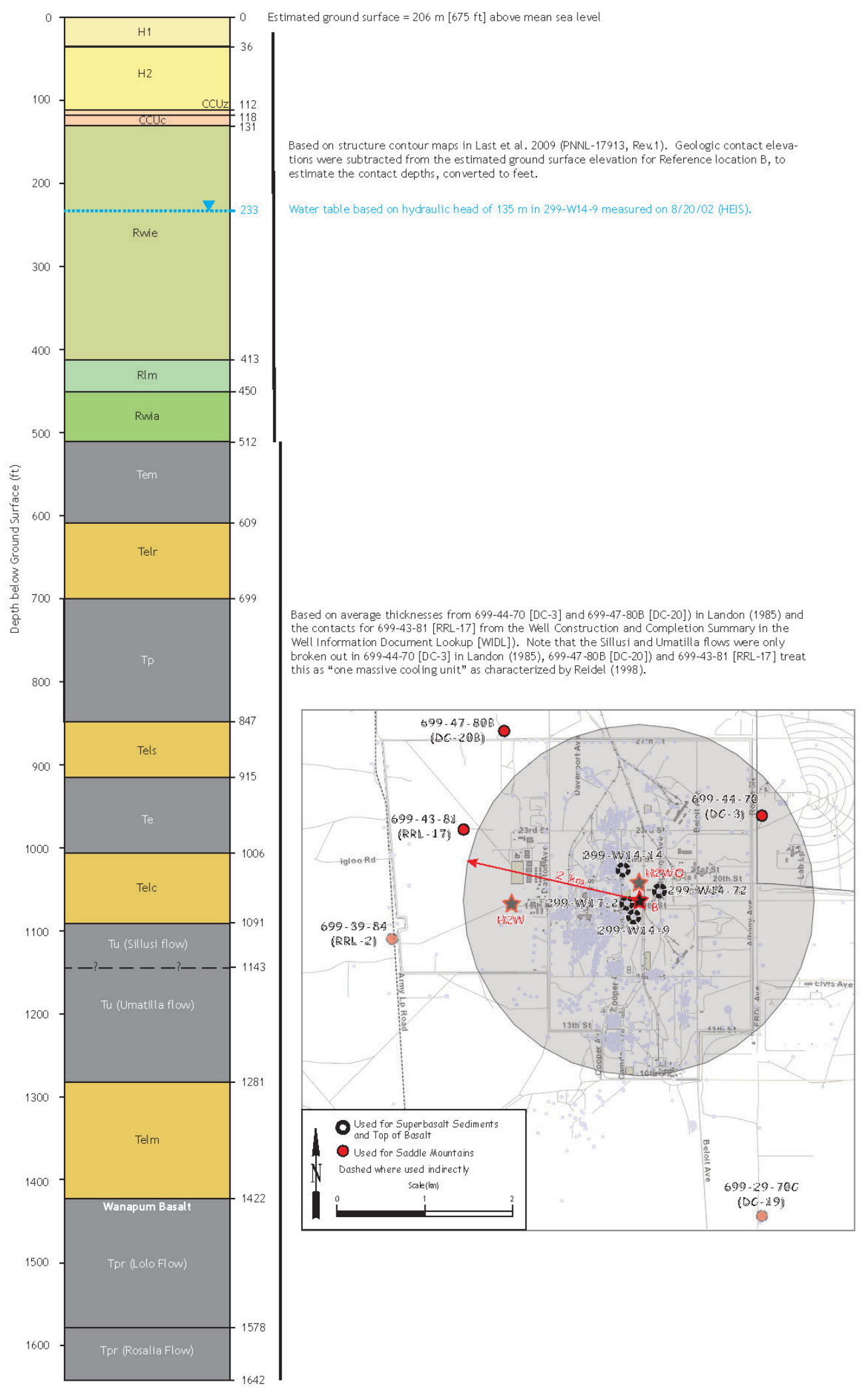


Plate 8a - General Deep Stratigraphy Beneath Seismometer Location B (200 W)

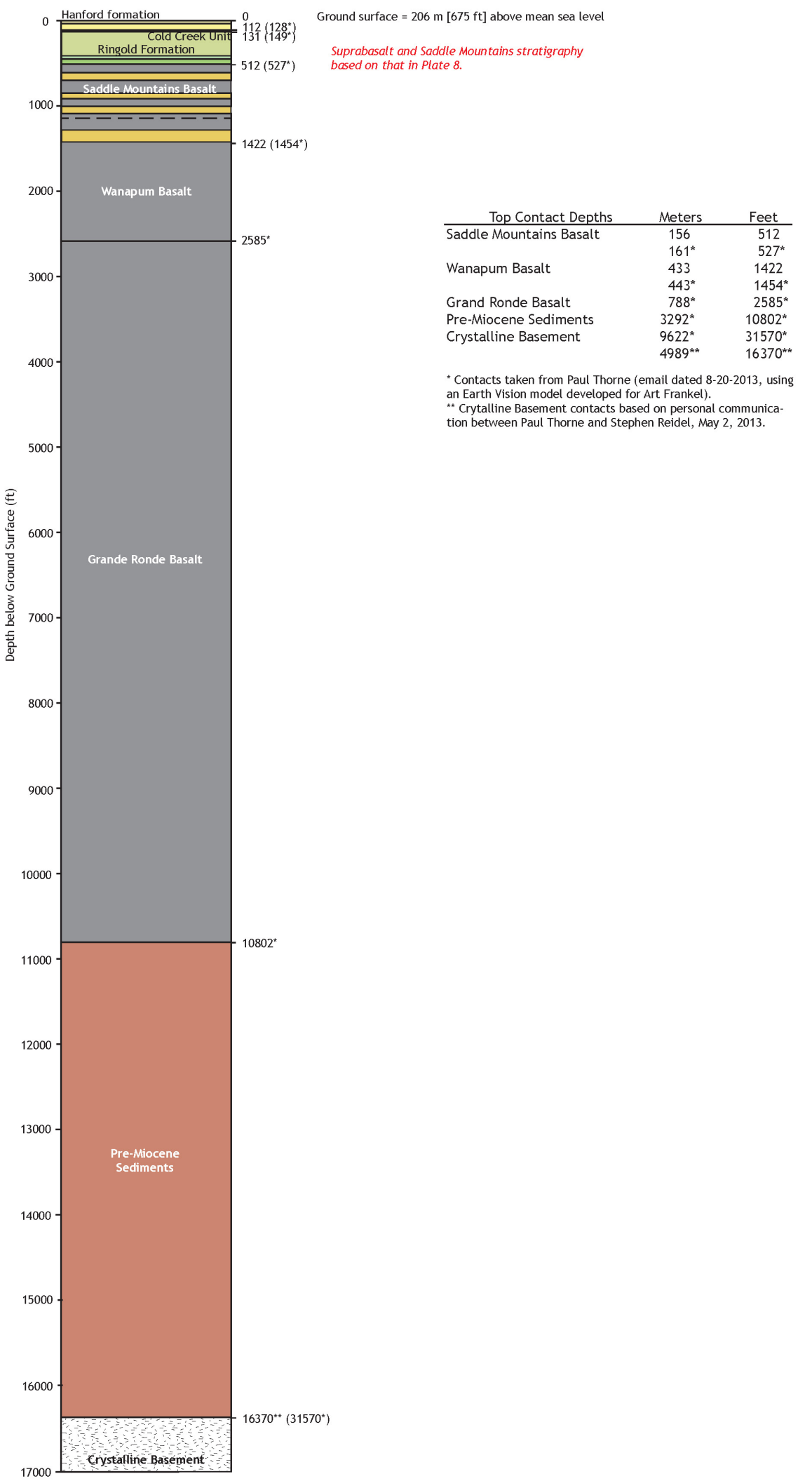


Plate 9 - General Stratigraphy Beneath Reference Location C (Columbia Generating Station)

(Based on Bechtel 2013 and wells 499-S1-8H [FFTF \#3], 699-2-E14 [DB-1], 699-15-E13 [DB-2] and 699-15-15G [DC-8])

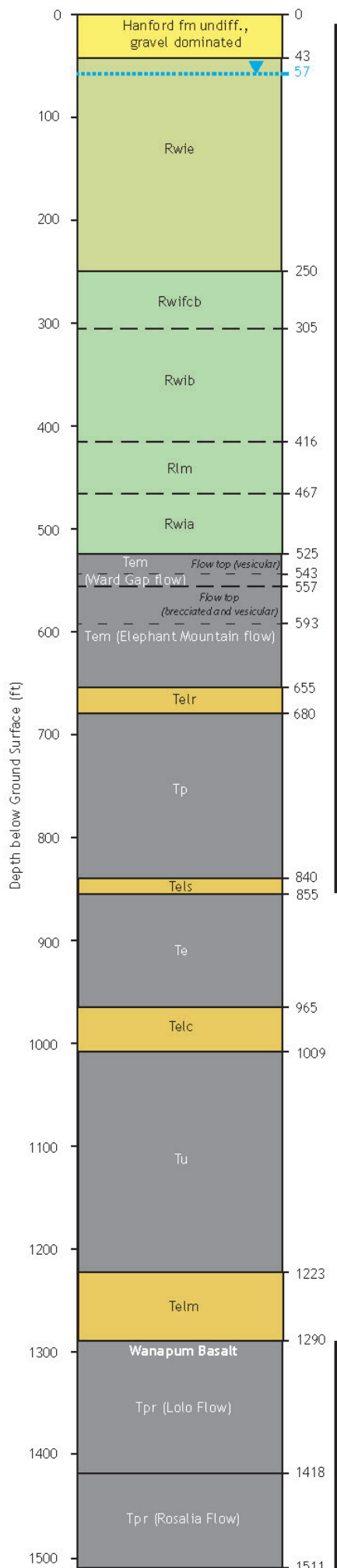

Plant grade $=441 \mathrm{ft}$ above mean sea level (Bechtel, 2013)

Water table based on hydraulic head of $117 \mathrm{~m}$ in 699-13-2D measured on 1/18/13 (HEIS),

Based on the stratigraphy in Bechtel 2013 |Assessment of Dynamic Geotechnical Data for the Columbia Generating Station Sitel. Additional detail for the lower portion of Ringold Formation is based on stratigraphic contacts for 699-12-1A (B-12) in Tho rne et al. (2006).

Additional detail for the Elephant Mountain member is based on average thicknesses in boreholes 699-516-E14 (DC-15) and 699-15-15G (DC-8) in Landon 1985.

Based on the average thicknesses for 499-51-8H (FFTF), 699-2-E14 (DB-1), and 699-15-E13 (DB-2) in Myers and Price 1981 |RHO-ST-14, Table A-2I, and 699-15-15G (DC-8) in Landon et al. 1985. Note that separate flows of the Umatilla member are not called out - instead, it is treated this as "one massive cooling unit" as characterized by Reidel (1998).

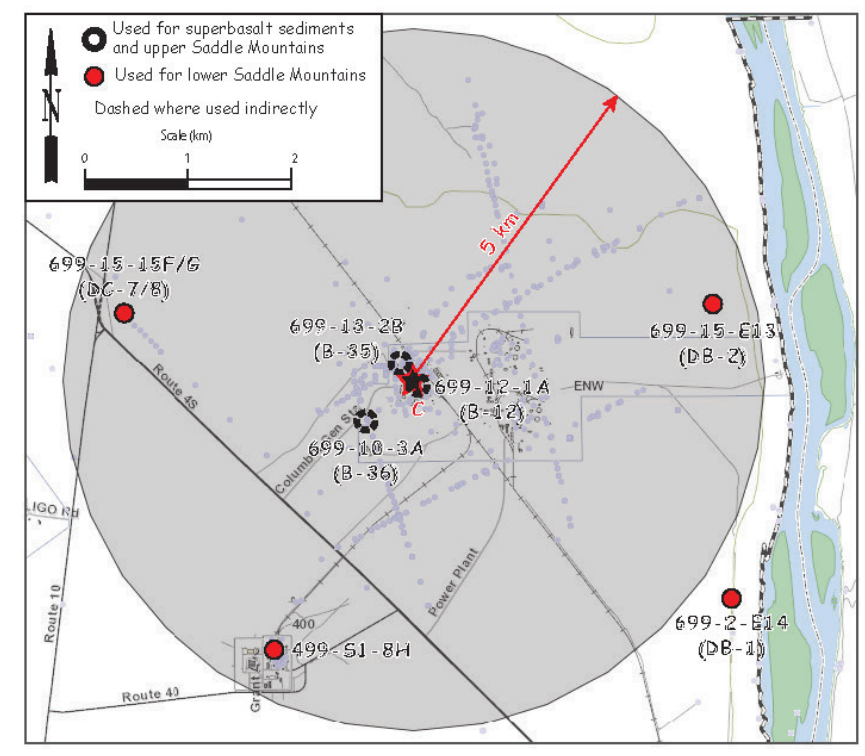

Based on flow thicknesses from 699-15-15G (DC-8) taken from Landon et al. 1985. 
Plate 9a - General Deep Stratigraphy Beneath eference Location C (Columbia Generating Station)

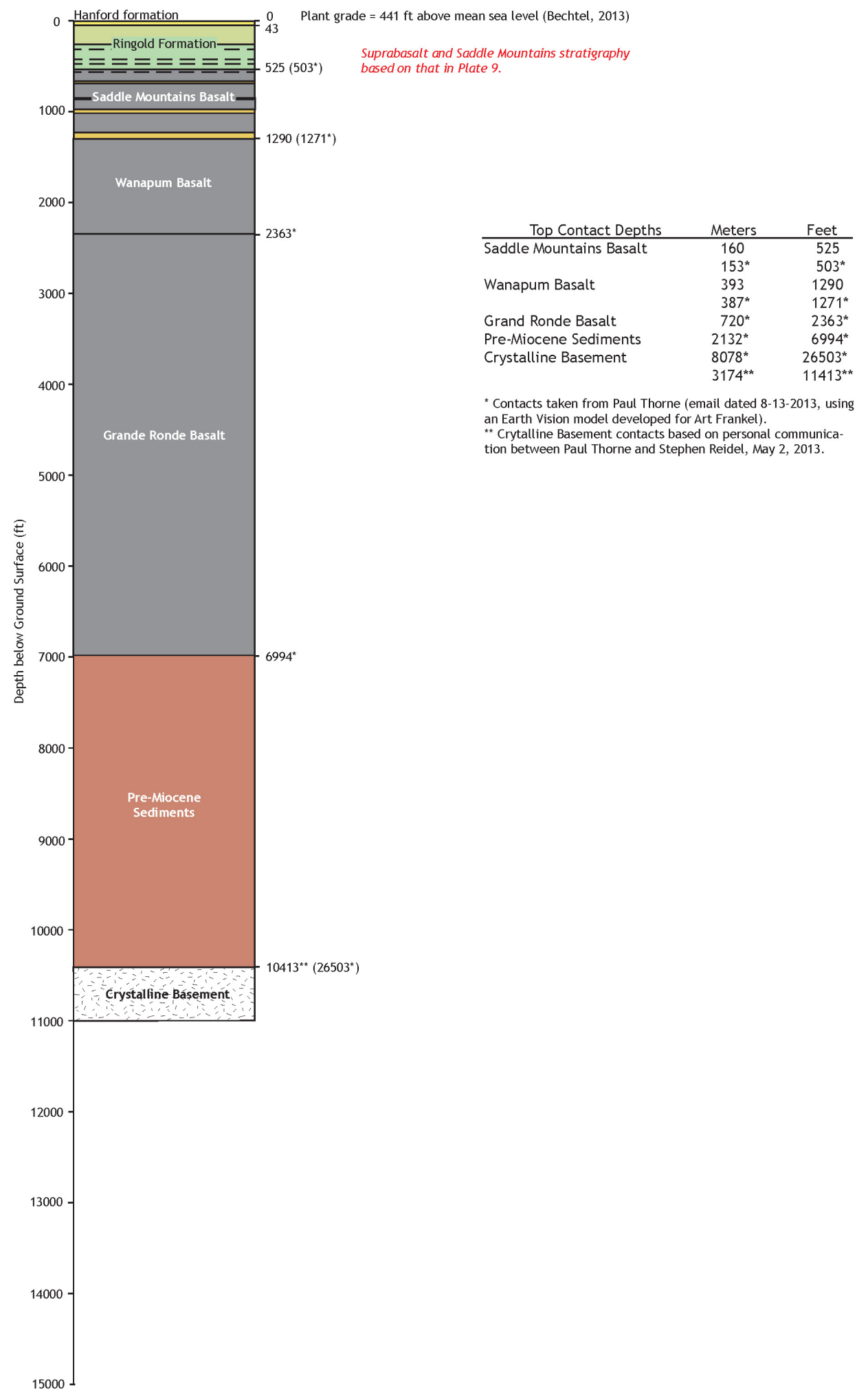




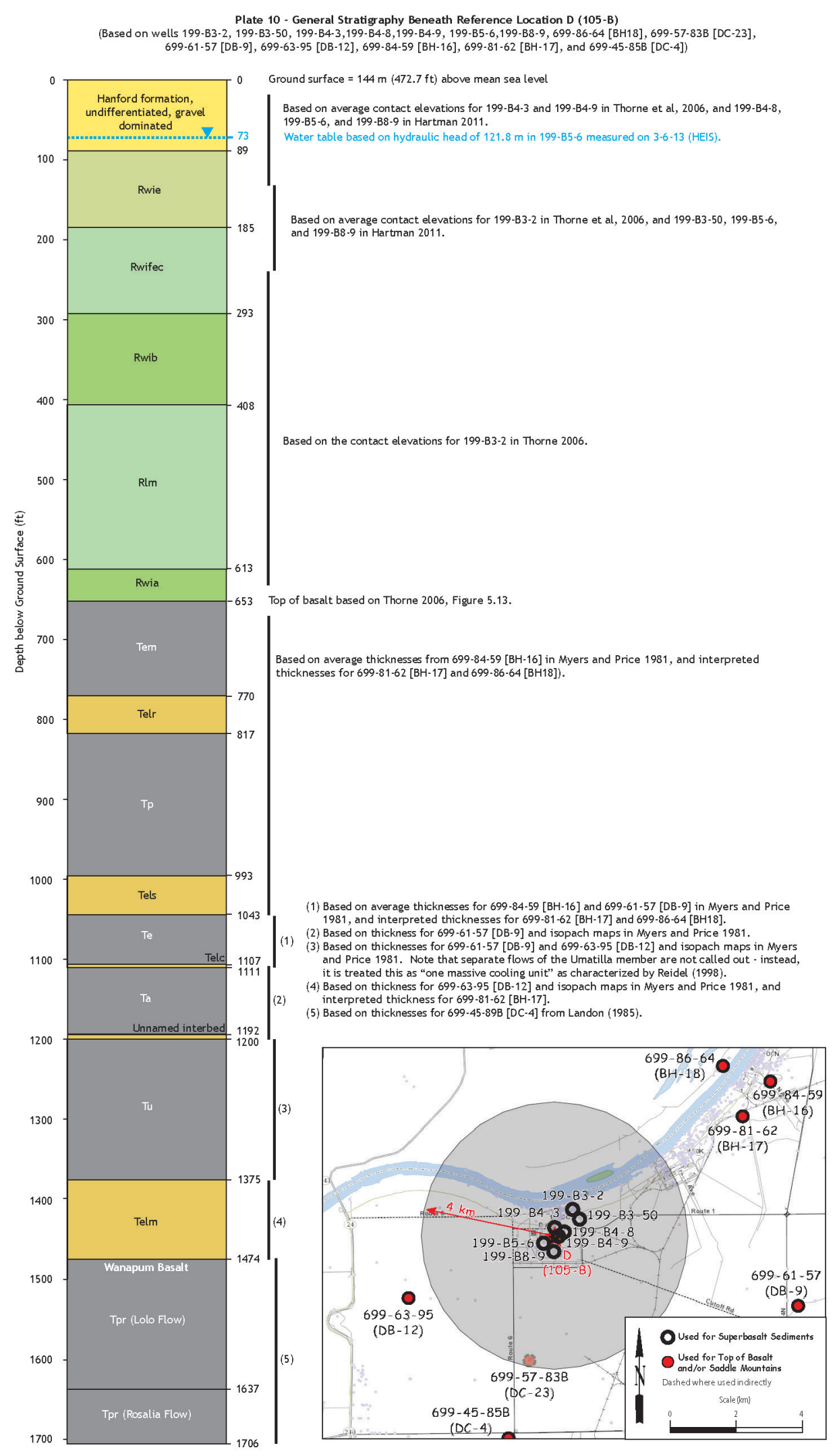




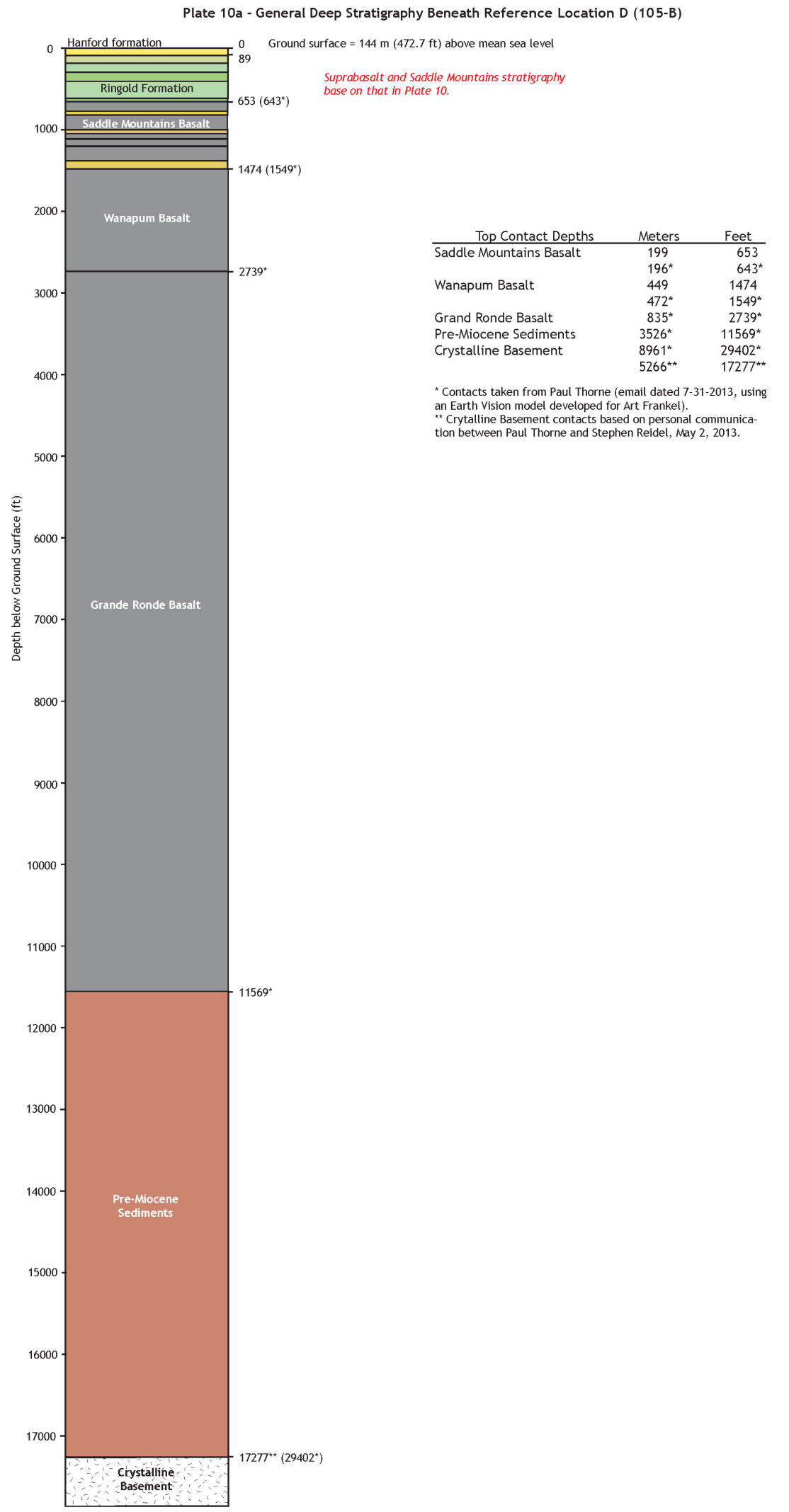




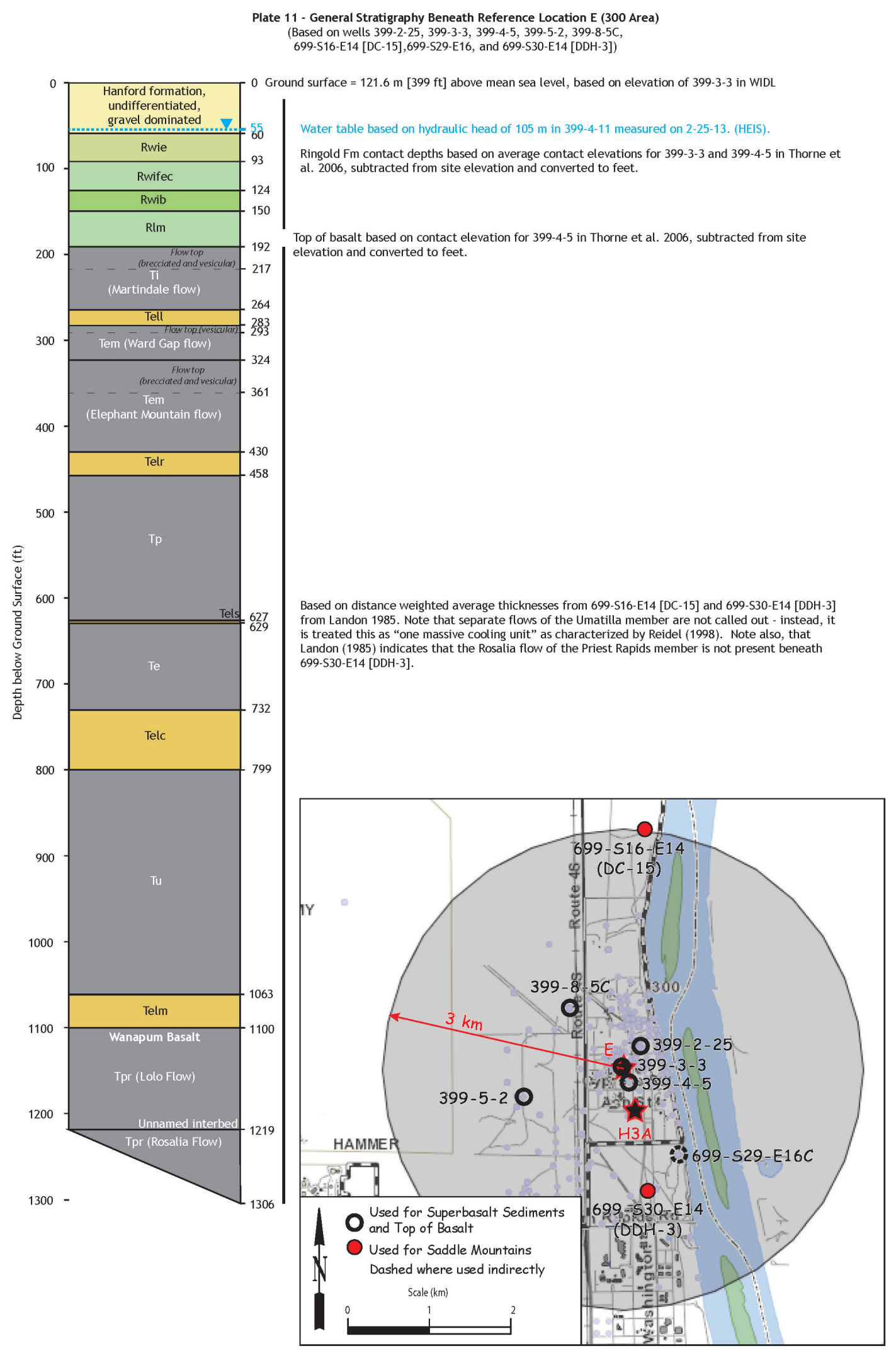


Plate 11a - General Deep Stratigraphy Beneath Seismometer Reference Location E (300 Area)

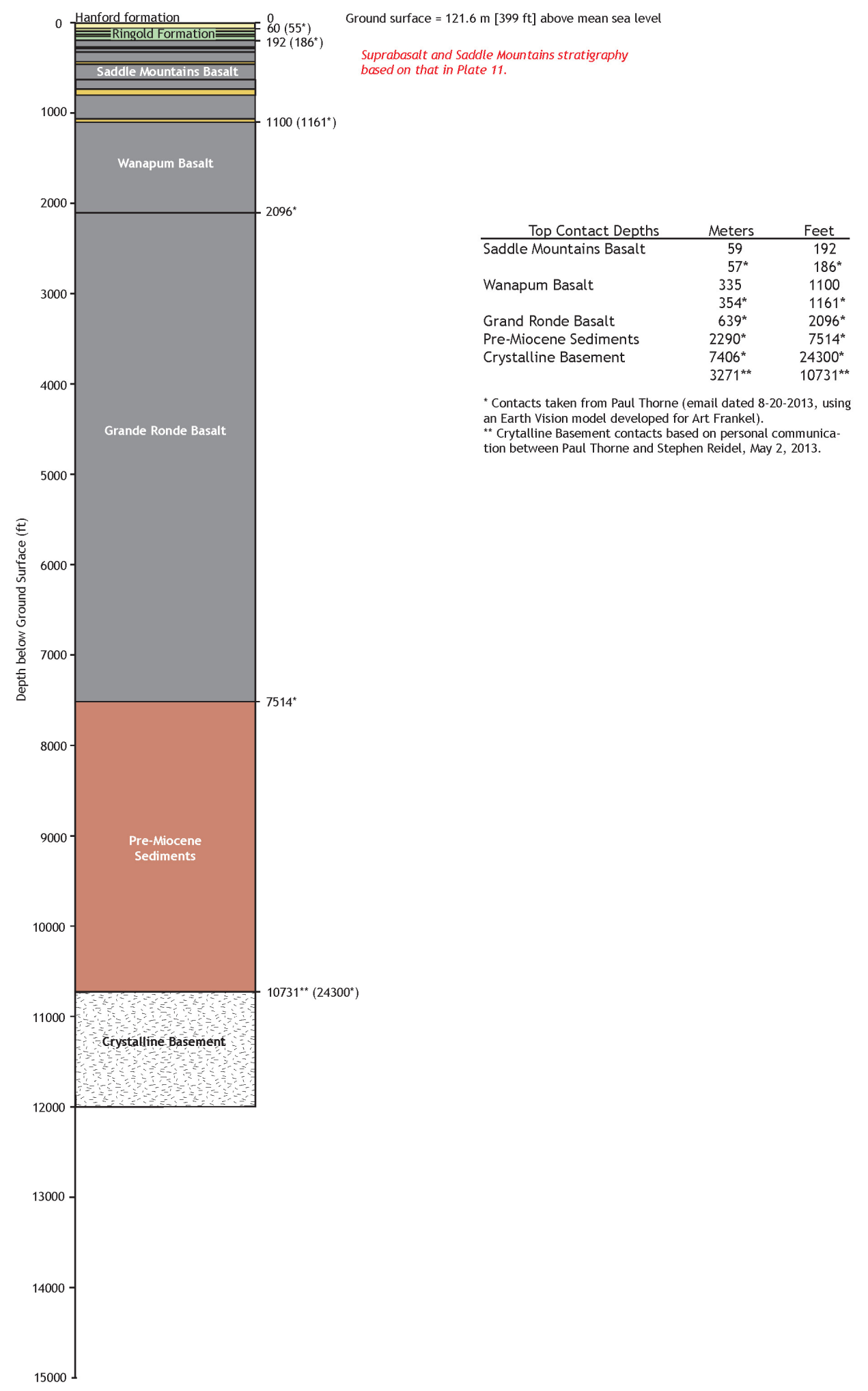


Plate 12 - General Stratigraphy Beneath Seismometer Station CCRK

(Based on the Three-Dimensional Hydrogeologic Framework Model of Columbia Plateau Regional Aquifer System Geologic Framework Mapper web interface (Burns et al. 2010), Well logs for WADOE Well ID 138747, and 699-49-100A [DB-11])

Ground surface $=533 \mathrm{~m}(1750 \mathrm{ft})$ above mean sea level (based on field recon. on Sept. 3, 2013

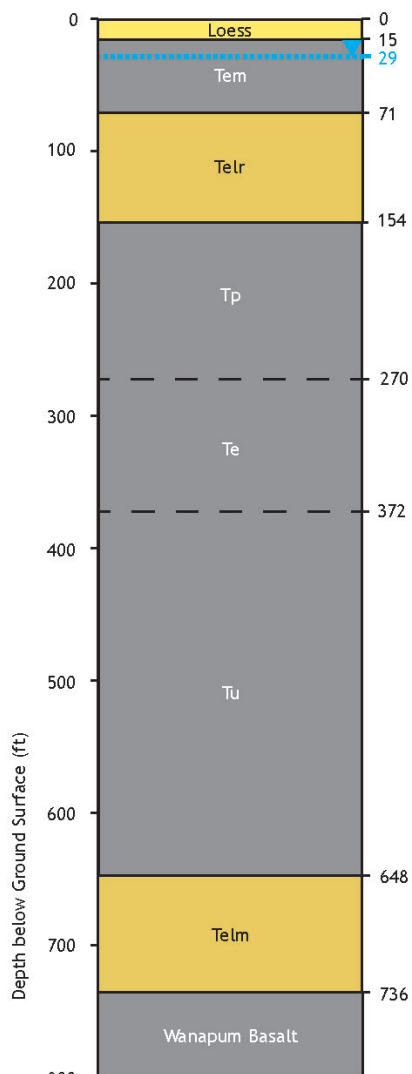

[email from Alan C. Rohay, dated Sept. 3, 2013])

Top of basalt elev. of $1735 \mathrm{ft}$ based on field recon. on Sept. 3, 2013 [email from Alan C. Rohay, dated Sept. 3, 2013]). This compares reasonbly with a top elev. for Saddle Mtns. Basalt of $1716 \mathrm{ft}$ was extracted from the Geologic Framework Mapper (Burns et al. 2010).

Static water level measured on 11/18/67 (well log from well 138747).

Based on thicknesses of interpreted strata from well logs of 138747 as correlated with other nearby wells and stratigraphic interpreations for 699-49-100A (DB-11) in Myers and Price (1981).

Top of Wanapum Basalt based on an elevation of $1014 \mathrm{ft}$ extracted from the Geologic Framework Mapper (Burns et al. 2010)

900

1000

1100

1200

300

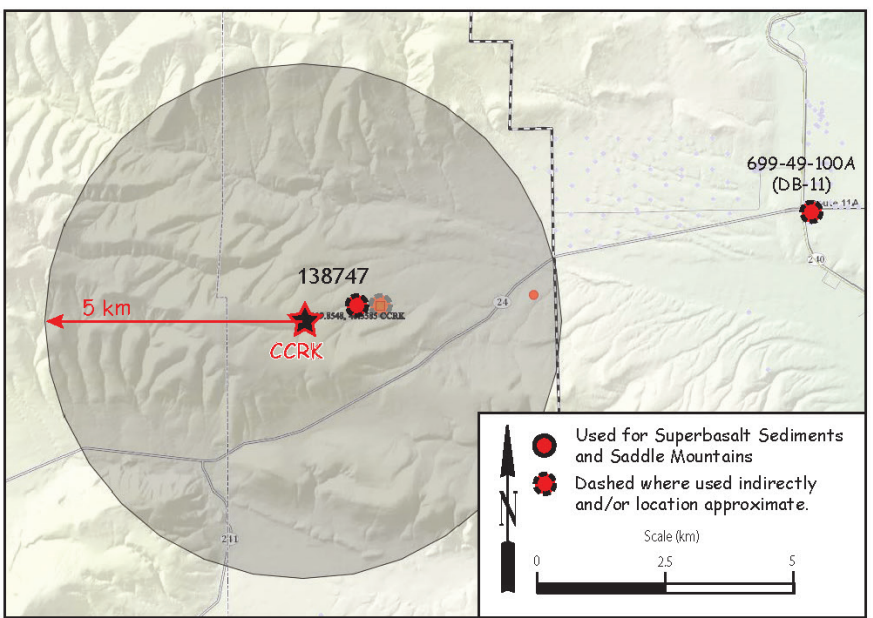

1500 


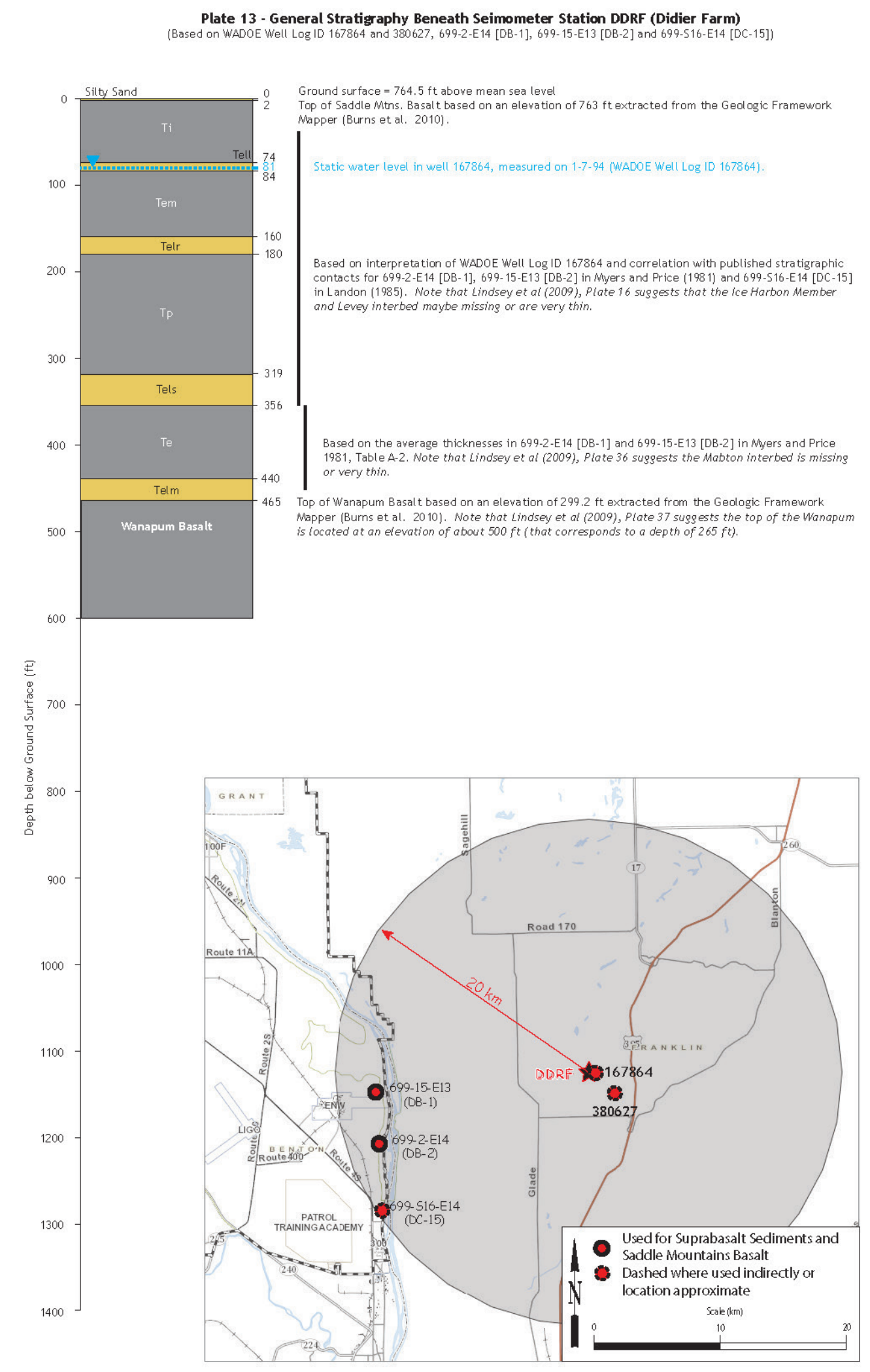


Plate 14 - General Stratigraphy Beneath Seimometer Station FHE (Frenchman Hills East)

(Based on WADOE Well Log ID 454842 and the Three-Dimensional Hydrogeologic Framework Model of Columbia Plateau Regional Aquifer System, Geologic Framework Mapper [Burns et al . 2012])

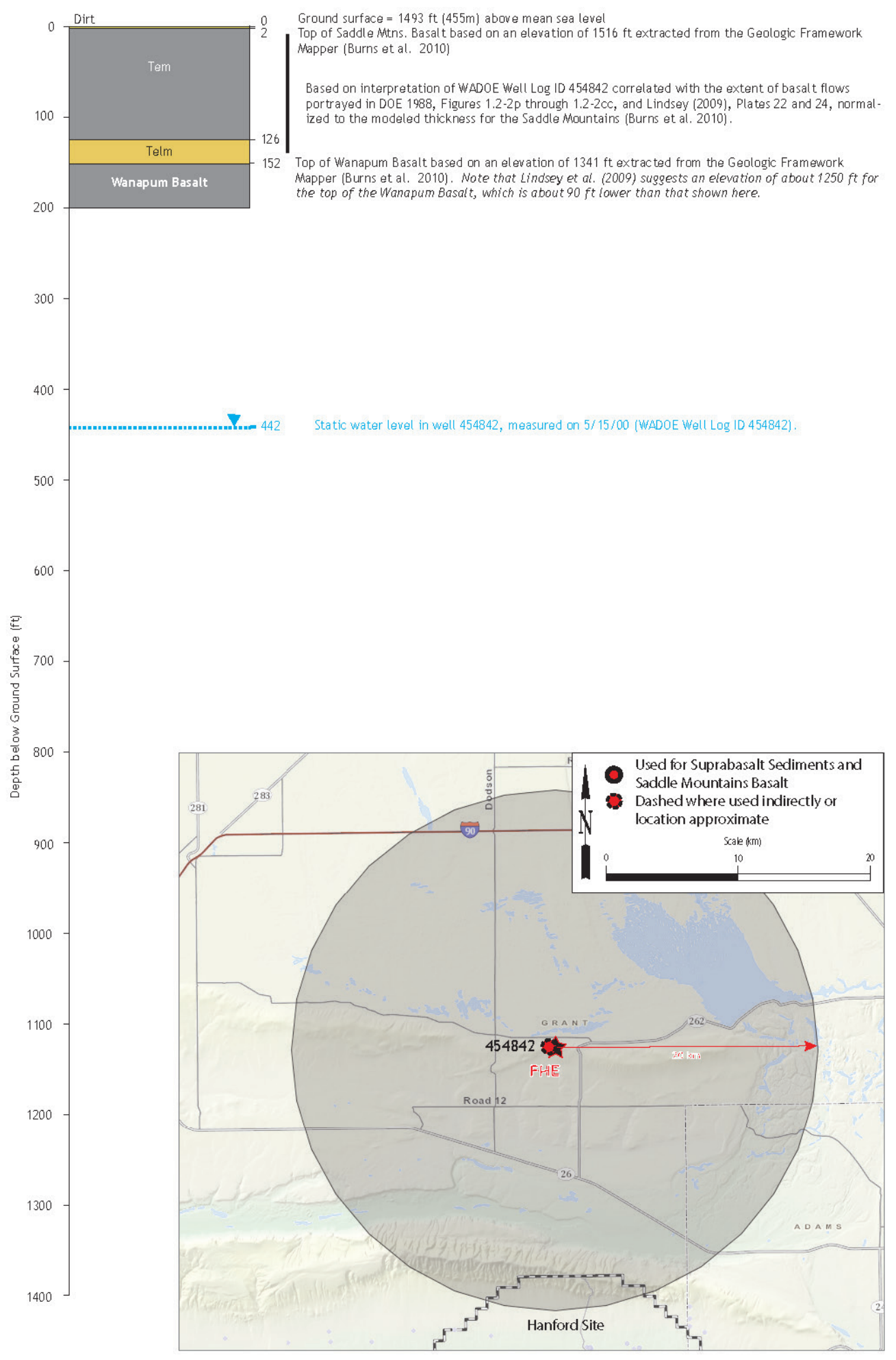


Plate 15 - General Stratigraphy Beneath Seimometer Station PHIN (Phinney Hill)

(Based on WADOE Well Log ID 302785 and the Three-Dimensional Hydrogeologic Framework Model of Columbia Plateau Regional Aquifer System, Geologic Framework Mapper [Burns et al. 2012])

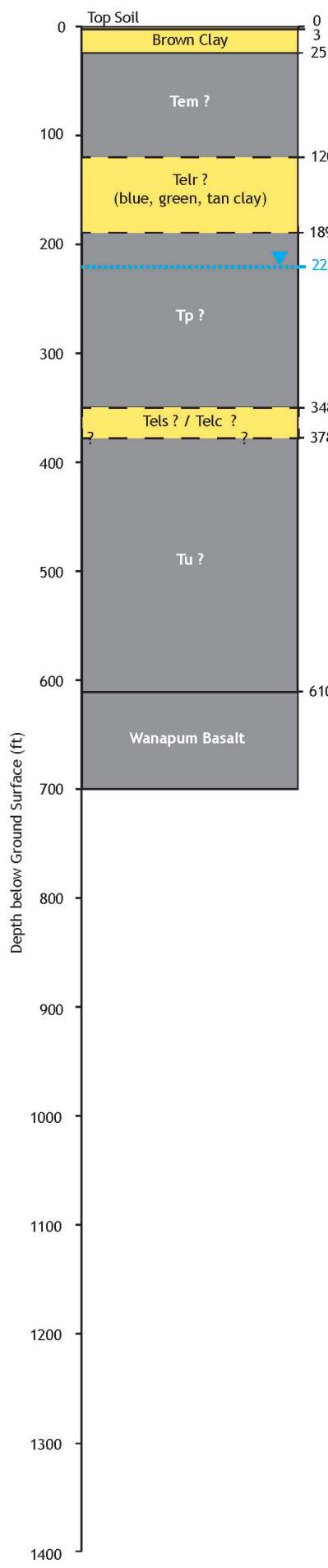

Ground surface $=745 \mathrm{ft}(227 \mathrm{~m})$ above mean sea level

Based on interpretation of WADOE Well Logs ID 302785 and 139808.

Saddle Mtns. Basalt based on an elevation of $725 \mathrm{ft}$ extracted from the Geologic Framework

Mapper (Burns et al. 2010).

Described as clay, blue and green clay, and caving tan clay in WADOE Well Logs ID 302785 and 139808.

Static water level in well 302785, measured on 2/26/01 (WADOE Well Log ID 302785).

Based on the average thickness described in WADOE Well Logs ID 302785 and 139808.

Described as blue to light grey clay or green to black sandstone and water bearing in WADOE Well Logs ID 302785 and 139808.

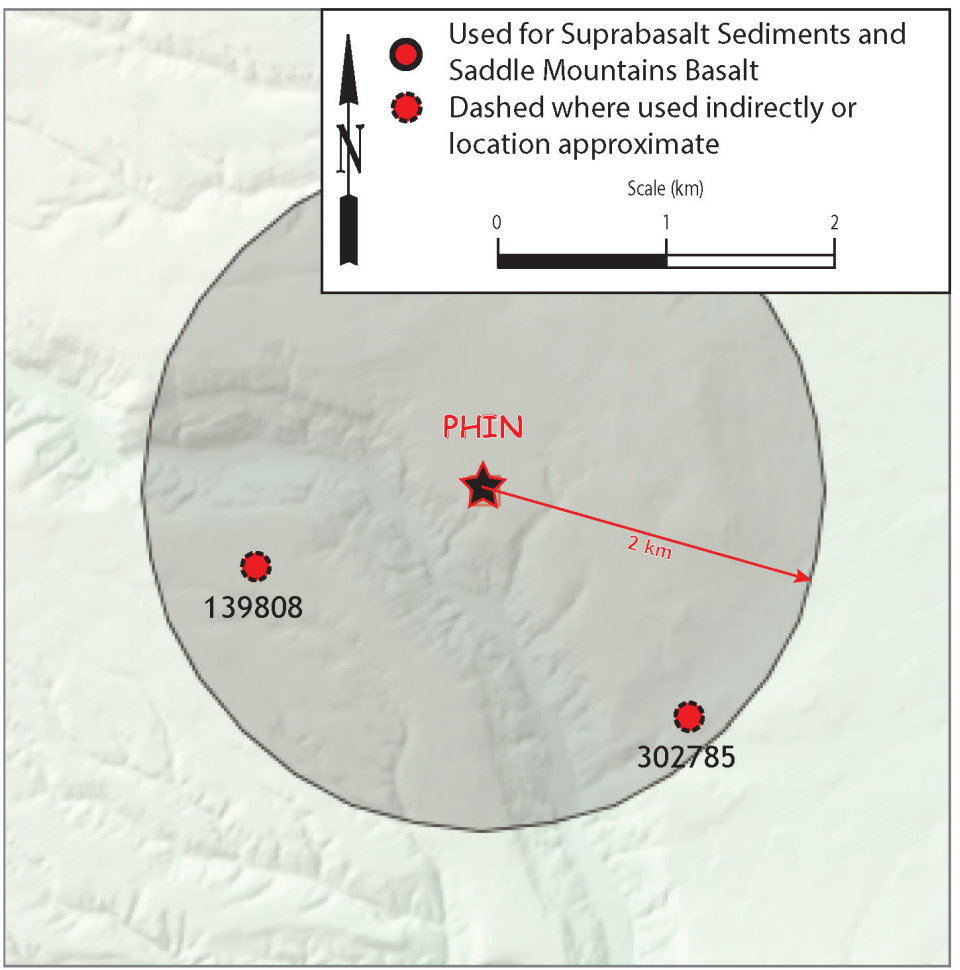




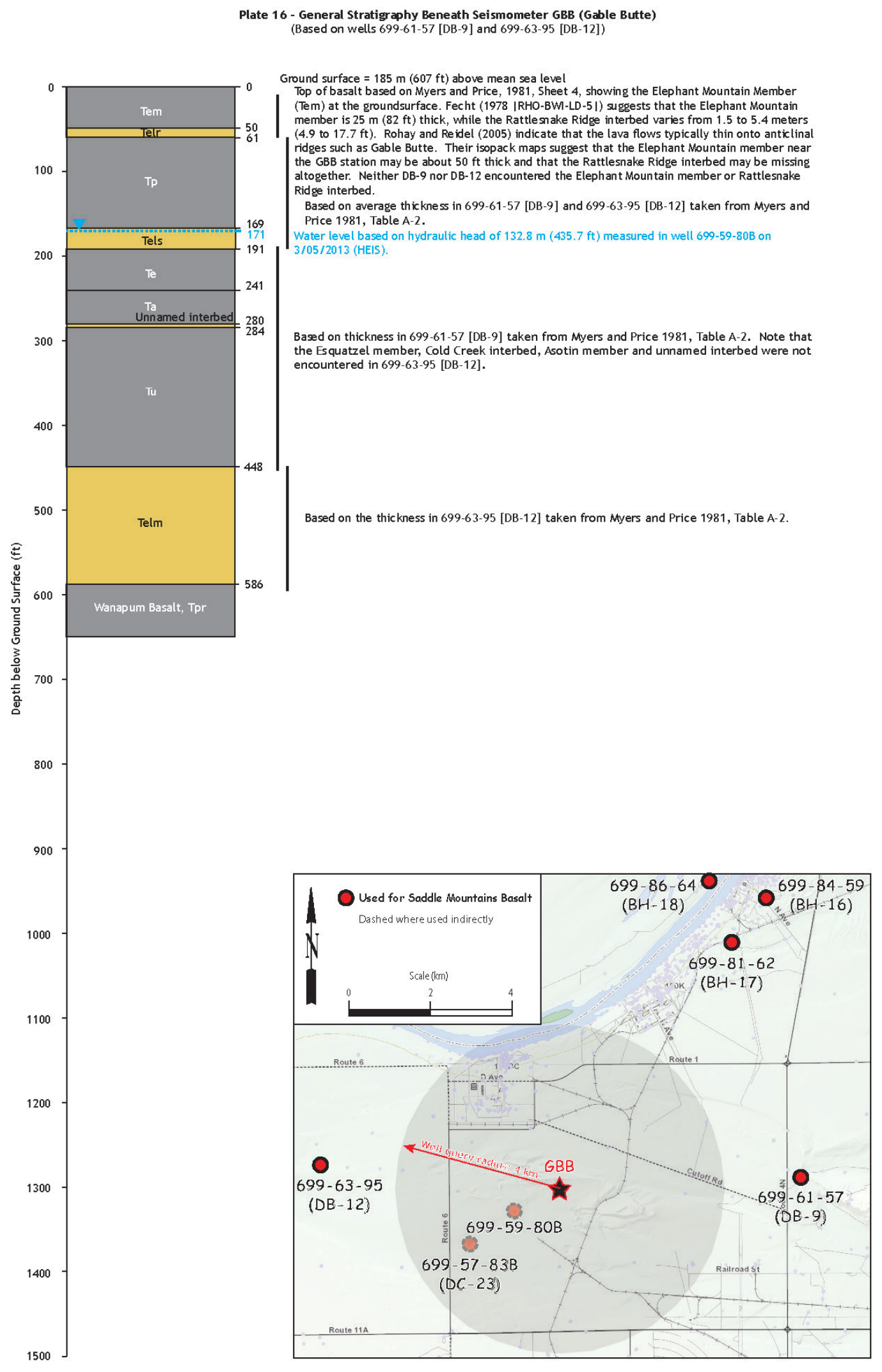




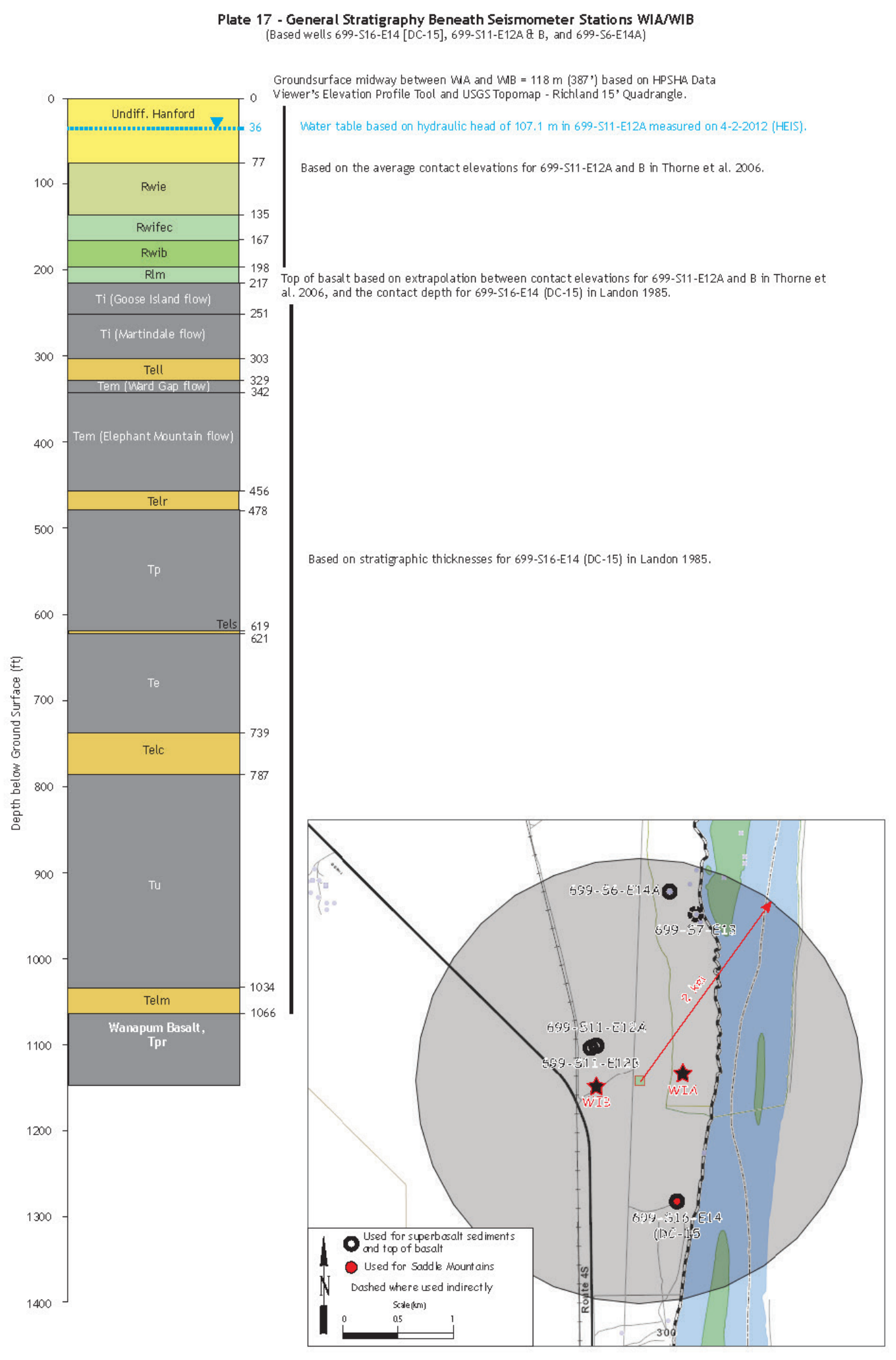




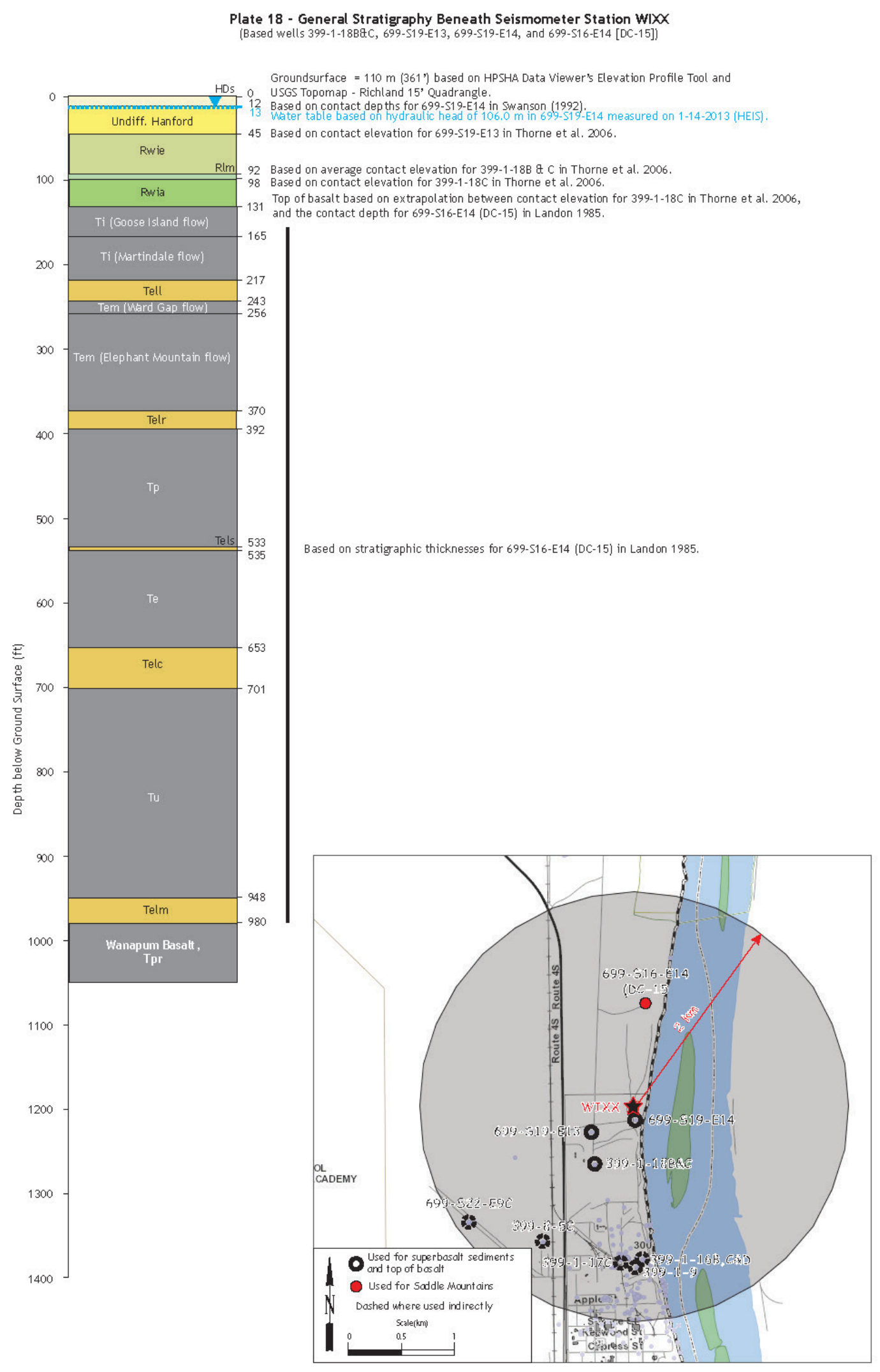




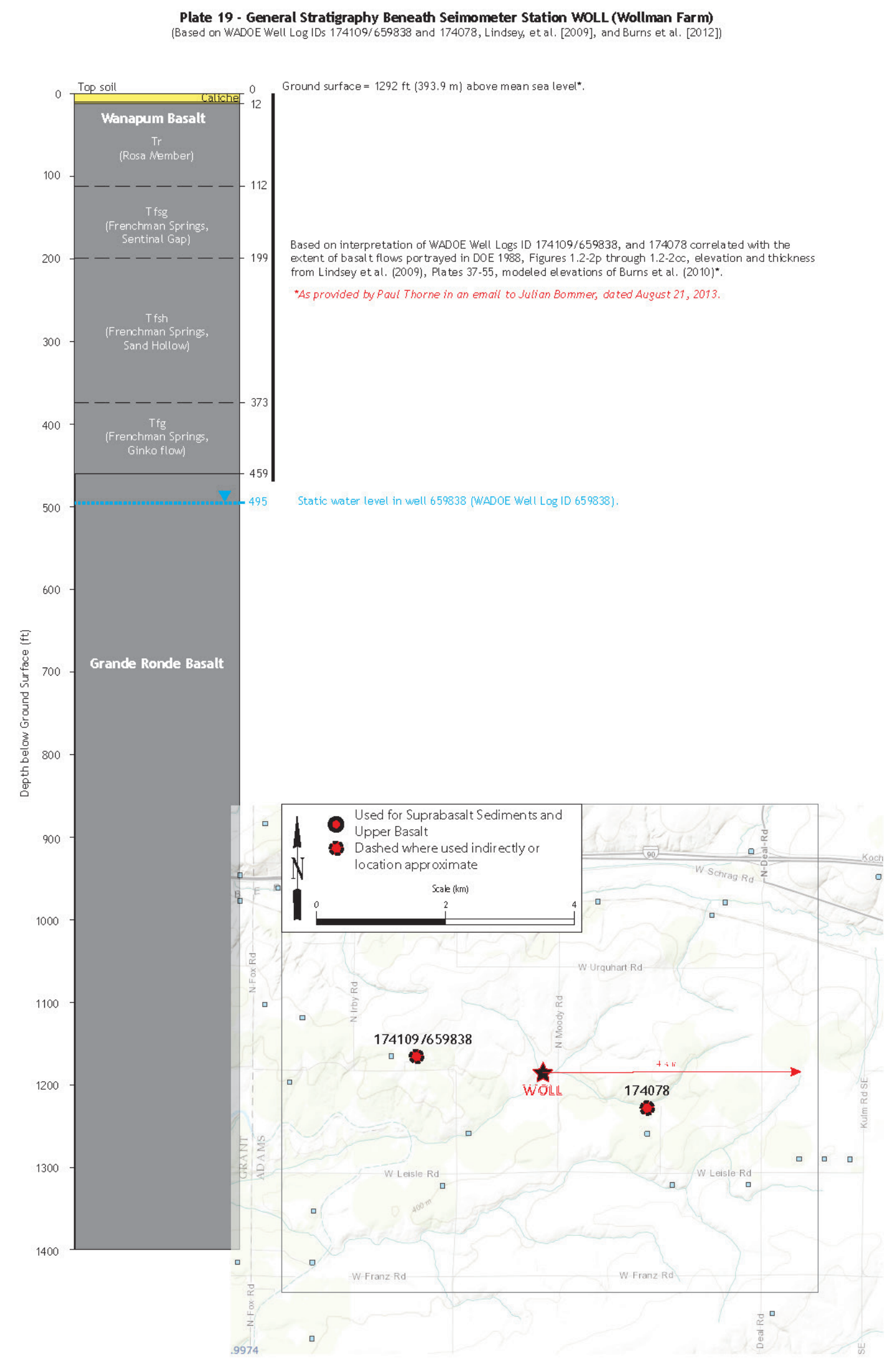

A. 31 


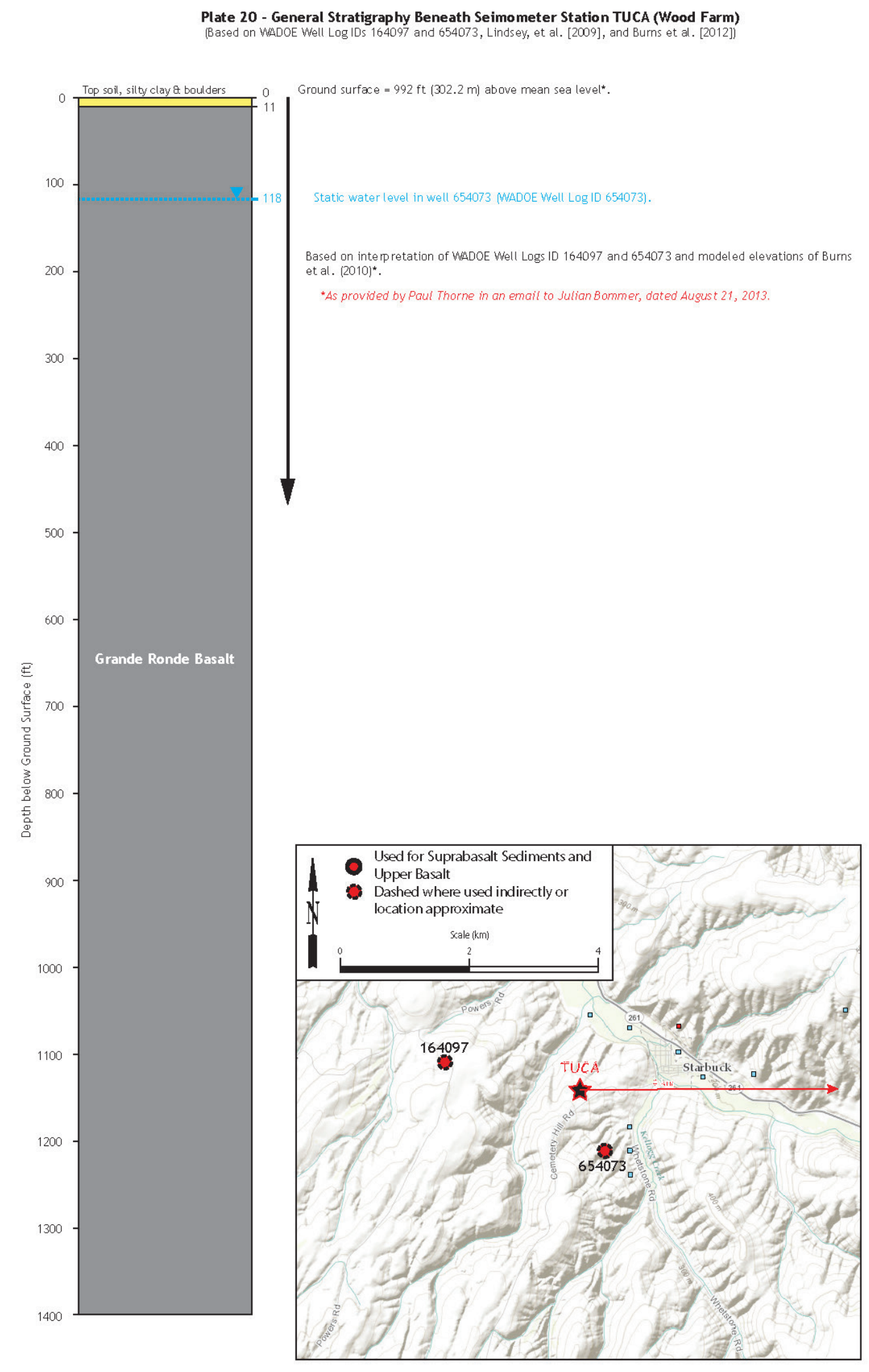

A. 32 


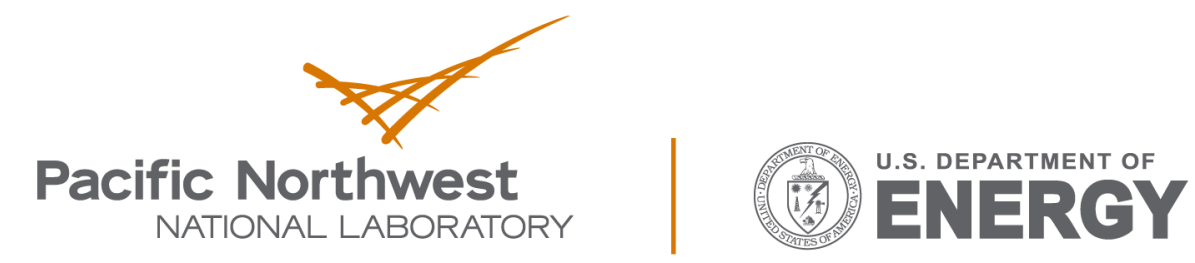

Proudly Operated by Battelle Since 1965

902 Battelle Boulevard

P.O. Box 999

Richland, WA 99352

1-888-375-PNNL (7665)

www.pnnl.gov 